\title{
Mineralogical, Chemical, and Isotopic Characterization of Fracture-Coating Minerals in Borehole Samples from Western Pahute Mesa and Oasis Valley, Nevada
}

\author{
F. Christopher Benedict, Jr., T. P. Rose, X. Zhou
}

U.S. Department of Energy

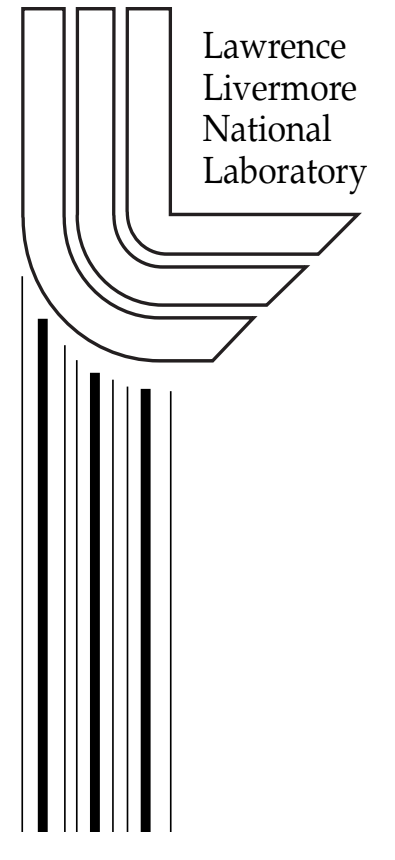

September 1, 2000 


\section{DISCLAIMER}

This document was prepared as an account of work sponsored by an agency of the United States Government. Neither the United States Government nor the University of California nor any of their employees, makes any warranty, express or implied, or assumes any legal liability or responsibility for the accuracy, completeness, or usefulness of any information, apparatus, product, or process disclosed, or represents that its use would not infringe privately owned rights. Reference herein to any specific commercial product, process, or service by trade name, trademark, manufacturer, or otherwise, does not necessarily constitute or imply its endorsement, recommendation, or favoring by the United States Government or the University of California. The views and opinions of authors expressed herein do not necessarily state or reflect those of the United States Government or the University of California, and shall not be used for advertising or product endorsement purposes.

This is a preprint of a paper intended for publication in a journal or proceedings. Since changes may be made before publication, this preprint is made available with the understanding that it will not be cited or reproduced without the permission of the author.

This work was performed under the auspices of the U. S. Department of Energy, by the University of California, Lawrence Livermore National Laboratory under Contract No. W-7405 Eng-48.

This report has been reproduced directly from the best available copy.

Available electronically at http://www.doc.gov/bridge

Available for a processing fee to U.S. Department of Energy

And its contractors in paper from

U.S. Department of Energy

Office of Scientific and Technical Information

P.O. Box 62

Oak Ridge, TN 37831-0062

Telephone: (865) 576-8401

Facsimile: (865) 576-5728

E-mail: reports@adonis.osti.gov

Available for the sale to the public from

U.S. Department of Commerce

National Technical Information Service

5285 Port Royal Road

Springfield, VA 22161

Telephone: (800) 553-6847

Facsimile: (703) 605-6900

E-mail: orders@ntis.fedworld.gov

Online ordering: http://www.ntis.gov/ordering.htm

\section{OR}

Lawrence Livermore National Laboratory

Technical Information Department's Digital Library

http://www.llnl.gov/tid/Library.html 


\title{
Mineralogical, Chemical, and Isotopic Characterization of Fracture-Coating Minerals in Borehole Samples from Western Pahute Mesa and Oasis Valley, Nevada
}

\author{
F. Christopher Benedict, Jr. ${ }^{1}$, Timothy P. Rose ${ }^{2}$, and Xiaoping Zhou ${ }^{3}$ \\ ${ }^{1}$ HSI-Geotrans, 6195 Ridgeview Ct., Suite D, Reno, NV 89509 \\ ${ }^{2}$ Analytical and Nuclear Chemistry Division, Lawrence Livermore National Laboratory, Livermore, CA 94550 \\ ${ }^{3}$ Harry Reid Center for Environmental Studies, University of Nevada, Las Vegas, NV 89154-4009
}

\section{Executive Summary}

This report summarizes the results of a mineralogical and geochemical investigation of fracture-coating phases obtained from archived borehole core and cuttings samples from the western Pahute Mesa-Oasis Valley region. The objective is to provide data needed to validate UGTA flow and transport models for this region. Fracture-lining minerals were characterized using micrographic techniques (SEM-EDS), and selected calcite samples were analyzed for their stable isotope $\left({ }^{13} \mathrm{C} /{ }^{12} \mathrm{C}\right.$ and $\left.{ }^{18} \mathrm{O} /{ }^{16} \mathrm{O}\right)$ and rare earth element (REE) abundances. The main conclusions are as follows:

(1) The distribution of fracture-lining mineral phases is a function of primary rock type, the style and degree of syn-depositional alteration, effects of post-depositional hydrothermal alteration, and fracture location relative to recharge waters (in the unsaturated zone) or through going groundwater (in the saturated zone).

(2) Fracture-lining minerals within the welded tuff aquifers (principally the Timber Mountain and Paintbrush Tuffs) are characterized by the assemblage calcite + chalcedony $+\mathrm{Fe}$ - and Mn-oxyhydroxides + mixed illite/smectite (in approximate decreasing order of abundance). The predominant mode of host rock alteration is quartzofeldspathic.

(3) Interbedded rhyolitic lava flow aquifers are characterized by the fracture-lining assemblage chalcedony + mixed illite/smectite + Fe- and Mn-oxyhydroxides \pm calcite \pm quartz \pm K-feldspar (in approximate decreasing order of abundance). These include lava flow aquifers from the Thirsty Canyon, Beatty Wash, Paintbrush, and Quartz Mountain groups. The predominant mode of host rock alteration is quartzofeldspathic.

(4) Fracture-lining zeolite minerals are abundant only within one of the basaltic lava flow aquifers (Trachyte of Ribbon Cliff) where they occur with chalcedony + calcite + clay minerals. 
(5) Stable isotope analyses $\left({ }^{13} \mathrm{C} /{ }^{12} \mathrm{C}\right.$ and $\left.{ }^{18} \mathrm{O} /{ }^{16} \mathrm{O}\right)$ of secondary calcite samples were used to deduce the origin and temperature of formation of the calcite. These data are also useful for constraining the geochemical evolution of dissolved inorganic carbon in groundwater flowpath models. Two general types of secondary calcite are recognized on the basis of temperature conditions.

(6) Low- to moderate-temperature calcite $\left(<45^{\circ} \mathrm{C}\right)$ was deposited from local recharge or from ambient regional groundwater flow. It contains carbon from either pedogenic (soil zone) or carbonate bedrock sources, and occurs at depths up to $2200 \mathrm{ft}$. It commonly forms transparent, euhedral crystals that may reflect recent precipitation from groundwater, especially in ER-EC-4 and -7.

(7) High-temperature calcite $\left(\sim 50\right.$ to $\left.116^{\circ} \mathrm{C}\right)$ was deposited from groundwater that previously equilibrated with carbonate bedrock, and is observed at depths greater than $\sim 1900 \mathrm{ft}$. It typically occurs as dense, opaque crystalline veins. It is most prevalent in wells located within the moat of the Timber Mountain caldera (particularly ER-EC-1, -5 and -6 ), and was probably deposited under hydrothermal conditions following earlier periods of volcanic activity.

(8) Variations in REE patterns for secondary calcite reflect the influence of groundwater chemistry, host rock chemistry, the carbonate source, and the physiochemical conditions of deposition. The partitioning of LREE relative to HREE is influenced by water chemistry (e.g. complexing with $\mathrm{HCO}_{3}{ }^{-}$and $\mathrm{SO}_{4}{ }^{2-}$ ions) and by the preferential substitution of LREE for $\mathrm{Ca}^{2+}$ in the calcite crystal lattice.

(9) Changes in the oxidation state of $\mathrm{Ce}$ and Eu are reflected as anomalies in chondriteand shale-normalized REE plots, and are useful indicators of redox conditions during calcite formation. Strong negative $\mathrm{Ce}$ and Eu anomalies are most pronounced in samples from relatively shallow depths, but are not observed in all "shallow" samples. In general, comparative studies of REE patterns in secondary calcite with REE patterns in groundwater are needed to determine the applicability of these data for constraining reactive flow and transport models. 


\subsection{Introduction}

The purpose of this study is to provide mineralogical and geochemical data for groundwater flow and transport models in support of the U.S. Department of Energy Nevada Operations Office (DOE/NV) Environmental Restoration Project at the Nevada Test Site (NTS). The NTS was the location of 828 underground nuclear tests conducted between 1951 and 1992 [U.S. Department of Energy, 1994]. Pahute Mesa provided sites for the deepest and largest yield tests, and contains about two-thirds of the total nuclear yield generated by the testing program [Laczniak et al., 1996; Bowen et al., 1994]. Most of the Pahute Mesa tests were conducted near or below the water table, resulting in groundwater contamination in the immediate vicinity of the underground test areas. The possibility of radionuclide migration beyond the NTS boundary prompted the DOE to initiate the Underground Test Area (UGTA) subproject, which is focused on defining the hydrologic boundaries encompassing groundwater resources that may be unsafe for domestic or municipal use [U.S. Department of Energy, 1997].

The subsurface hydrogeology of the western Pahute Mesa-Oasis Valley (WPM-OV) region is complex. Water moves primarily along interconnected fractures in discontinuous lava-flow and welded tuff aquifers that are locally offset by caldera forming and younger high-angle faults [Laczniak et al., 1996; Blankennagel and Weir, 1973]. Deep regional groundwater moves southwestward beneath Pahute Mesa toward the Oasis Valley groundwater discharge area, where approximately 8000 acre-feet (ac-ft) of groundwater discharges annually via evapotranspiration and spring flow [Reiner et al., 1999].

A preliminary geochemical model for groundwater flow paths between Pahute Mesa and Oasis Valley was developed for the UGTA project in FY 1998 and 1999 [Thomas et al., 1999]. One of the key limitations in the model development was a lack of fracture-lining mineral data in the down gradient area. In particular, it was found that several potential flow paths could not be modeled within reasonable rates of mass transfer using existing mineral data from boreholes on Pahute Mesa [IT Corporation, 1998b; Rose et al., 1999]. Fracture-lining minerals provide the best indicators of the phases that are dissolving or precipitating along the flowpath, and are an essential component of reactive transport models. The recent construction of new wells in the WPM-OV region [IT Corporation, 1998a; Robledo et al., 1998] has afforded the opportunity to obtain new detailed information regarding the hydrogeology of this region, including the mineralogy and geochemistry of fracture-lining phases.

This report describes the mineralogy of fracture-lining phases in volcanic rocks from the WPM-OV region, and includes stable isotope ratio $\left({ }^{13} \mathrm{C} /{ }^{12} \mathrm{C}\right.$ and $\left.{ }^{18} \mathrm{O} /{ }^{16} \mathrm{O}\right)$ and rare-earth element (REE) data for fracture-lining calcite. Calcite was given particular attention because it is a key phase governing the chemical evolution of the groundwater in this 
region. Samples were obtained from archival drill core and cuttings housed in the U.S. Geological Survey Core Library in Mercury, Nevada. Forty-seven core and cuttings samples were initially selected from depths corresponding to the screened intervals in 16 different wells. Many of the samples are from the newly developed ER-EC wells [IT Corporation, 1998a] with additional samples from wells located in Oasis Valley [Robledo et al., 1998] and the western NTS. Well locations are shown in Figure 1. Four samples originally selected for isotopic study contained insufficient amounts of calcite for analysis. These included samples from ER-OV-1 (160 ft), ER-OV-2 (190 ft), ER-OV-6a $(520 \mathrm{ft})$, and ER-OV-6a2 (10 ft). No further information is reported for these samples.

The data reported here augment the results of previous investigations of fracture-lining minerals from Pahute Mesa boreholes [IT Corporation, 1998b; Rose et al., 1999]. The combined data from these studies provides a comprehensive database for interpreting fluid and solute movement in the WPM-OV groundwater flow system, and will assist in constraining geochemical models for this region [Thomas et al., 1999]. The fracturelining mineral data also supports on-going efforts to model radionuclide migration in the near-field environment beneath Pahute Mesa [e.g. Wolfsberg et al., 1999; Smith et al., 2000; Maxwell et al., 2000]. 


\subsection{Methods}

Sample properties that were evaluated during this study include:

- Sample mineralogy

- Qualitative major element chemistry of selected mineral phases that are assumed to be relatively soluble (e.g. feldspars and carbonate minerals) or phases that are assumed to be effective substrates for the adsorption of dissolved solutes (e.g. zeolites, iron and manganese oxides)

- Stable isotope analyses $\left({ }^{13} \mathrm{C} /{ }^{12} \mathrm{C}\right.$ and $\left.{ }^{18} \mathrm{O} /{ }^{16} \mathrm{O}\right)$ of secondary calcite

- Rare earth element (REE) concentrations of secondary calcite.

Twenty-five samples were analyzed using scanning electron micrographic techniques. An additional 18 calcite samples were analyzed for stable isotopes, seven of which were also analyzed for their REE concentrations. The samples selected for analysis are summarized in Table 1.

\subsection{Micrographic Analytical Methods}

The mineralogy and qualitative major element chemistry of fracture-coating phases was evaluated using scanning electron micrographic techniques. The scanning electron microscope (SEM) analyses were conducted using the facilities at Los Alamos National Laboratory, with the assistance of Peg Snow (LANL EES-1). The SEM used is a Tracor ADEM coupled with an EDS (energy dispersive spectrometry) system. Typical accelerating voltage used on the SEM was $20 \mathrm{kV}$. In the case of sidewall cores and core samples, portions of the natural exposed open fracture surfaces (up to $4 \mathrm{~cm} \times 5 \mathrm{~cm}$ ) were separated from the main sample and prepared for analysis. Hand-selected pieces of drill cuttings (up to $1 \mathrm{~cm} \times 2 \mathrm{~cm}$ ) exhibiting coated fractures and/or vesicles were also prepared for analysis. These samples were carbon-coated for textural and mineralogical evaluation in the SEM. The results of the micrographic analyses are included in Appendix 1 and summarized in Table 2 .

\subsection{Isotopic Analyses of Secondary Calcite}

The stable isotope ratios of carbon $\left({ }^{13} \mathrm{C} /{ }^{12} \mathrm{C}\right)$ and oxygen $\left({ }^{18} \mathrm{O} /{ }^{16} \mathrm{O}\right)$ were measured for eighteen calcite samples from nine WPM-OV boreholes. Calcite was reacted with $100 \%$ phosphoric acid at $25^{\circ} \mathrm{C}$ [McCrea, 1950] and the resulting $\mathrm{CO}_{2}$ gas was extracted and purified on a vacuum line. Carbon and oxygen stable isotope ratios were measured on a VG Prism mass spectrometer. Results are reported in the conventional $\delta$ notation as per mil (\%o) variations relative to the PDB (carbon) and SMOW (oxygen) standards. Analytical reproducibility is \pm 0.1 per mil for carbon and \pm 0.15 per mil for oxygen. Analytical results are summarized in Table 3 . 
The $\mathrm{CO}_{2}$ gas from one sample was reduced to graphite and analyzed for ${ }^{14} \mathrm{C}$ on an accelerator mass spectrometry at Lawrence Livermore National Laboratory [Vogel et al., 1987]. Results are reported as percent modern carbon (pmc) relative to 0.95 times the specific activity of the NIST oxalic acid standard reference material [Stuiver and Polach, 1977]. The radiocarbon age was calculated using a half-life of 5730 years.

\subsection{Rare Earth Element Analyses of Secondary Calcite}

Rare earth element (REE) concentrations were measured for 7 calcite samples using inductively coupled plasma mass spectrometry (ICP-MS) (Perkin-Elmer ${ }^{\circledR}$ Elan 5000). Calcite was separated from the host rock using dental tools and picks, ground in a mortar and pestle, and washed using distilled water. Approximately 0.25 grams of each calcite sample was placed in ultraclean Teflon ${ }^{\circledR}$-lined microwave digestion bombs with $2.5 \mathrm{~mL}$ of ultrapure $\mathrm{HF}$ (Seastar) and $2.5 \mathrm{~mL}$ of ultrapure $\mathrm{HNO}_{3}$ (Seastar). The digestion bombs were then sealed and placed in a microwave oven (CEM Corporation MDS-2100) and heated to $160^{\circ} \mathrm{C}$ at a pressure of $8.62 \times 10^{5} \mathrm{~Pa}(125$ p.s.i.) for 25 minutes. The samples were allowed to cool before $30 \mathrm{~mL}$ of a saturated boric acid solution was added to each sample. The samples were subsequently heated again in the microwave for 5 minutes at $70^{\circ} \mathrm{C}$ at 1-2 p.s.i.. The dissolved rock samples were then decanted into clean polyethylene bottles and diluted by a dilution factor of 2000 before analysis by ICP-MS. A series of 5 standards of known concentrations (i.e., 0.05, 0.5, 1.0, 5.0 and $10.0 \mu \mathrm{g} / \mathrm{kg}$ ) were prepared and routinely monitored during analysis in order to calibrate the instrument, check the calibration, and calculate the rock sample REE concentrations. During the analyses, the U.S. Geological Survey rock standard W-2 (diabase) was included as a reference standard. Measured W-2 concentrations never deviated by more than $10 \%$ from the reference concentration. A duplicate sample and a method blank have been analyzed for quality control purposes. REE analytical results are summarized in Table 4. 


\subsection{Sample Descriptions}

Detailed descriptions of samples that were evaluated using SEM-EDS techniques are found in Appendix 1. A selected number of SEM photomicrographs are included to illustrate important mineralogical or textural features. Appendix 2 contains descriptions of the calcite samples that were analyzed for stable isotopes and rare earth element abundances.

Table 1 provides a summary description of all the samples that were analyzed during this study, and includes the following information: (1) well and depth interval; (2) physical description of the sample; (3) hydrostratigraphic unit; (4) stratigraphy/lithology; (5) type of rock alteration; (5) physical characteristics of the fracture; (6) fracture-lining phases that are present; (7) physical evidence for phase dissolution; and (8) the types of analyses that were conducted. Data for the hydrostratigraphy, lithology and type of rock alteration were obtained from unpublished lithologic logs provided by Bechtel Nevada (L.B. Prothro, 1999, written communication). 


\subsection{Results}

\subsection{Micrographic Results}

The results of the micrographic characterization are included in Appendix 1. Data from the SEM analysis are summarized in Table 2. Based on these micrographic analyses the following statements can be made regarding the samples observed.

$>$ Reactive fracture coating phases are widespread and variable in fractured rock in the Pahute Mesa - Oasis Valley flow system. These phases include both Fe- and Mnoxides as well as zeolites, clay minerals, and silica polymorphs. It has been observed in this study that, at least locally, Mn-oxides are an important fracture coating phase and can represent up to $30 \%$ of the available surface area. This is consistent with previous observations (IT Corp, 1998b; Reimus et al, 2000; Rose et al, 1999). This imparts important consideration to solute transport modeling which, to date, has focused largely on Fe-oxides.

While compromised by the lack of drill core from recently completed boreholes and being restricted to cuttings and limited sidewall cores, it appears that the development of reactive fracture coating phases is enhanced in rocks with an increased tendency toward secondary permeability. This specifically includes the quartzofeldspathic alteration facies of structurally competent rocks such as welded tuff and rhyolitic lava flows.

$>$ Possible water rock interaction processes can potentially include identified phases (such as the base metal bearing phases identified in ER-EC-5 and UE-29a\#2, and RRE-bearing carbonate in ER-EC-6) on existing fracture surfaces that have resulted from earlier hydrothermal processes as well as those that are more typically formed in response to through going groundwater. This suggests that, at least locally, relatively unique geochemical sources and sinks exist along the flow path. This also indicates that many of the fractures likely to host groundwater movement in the present day Pahute Mesa - Oasis Valley flow system have acted as conduits for fluid movement under conditions significantly different from those currently observed for a significant period of time.

The identification of secondary dolomite in ER-EC-4 may result in enhanced geochemical flow path identification down gradient from Pahute Mesa. Previous geochemical flow path modeling (Thomas et al, 1999) could not adequately constrain certain flow paths due to an unrealistic degree of mass transfer required along the flow path using the previously identified $\mathrm{Mg}$ - bearing phases (Mg-montmorillonite).

While clear evidence of calcite precipitation was not observed in samples evaluated using the SEM, petrographic analysis of calcites subject to isotopic analysis (see Appendix 2) indicates that calcite appears to be precipitating in places down gradient from Pahute Mesa. This is consistent with predictions based on saturation indices 
calculated in Thomas et al (1999). Calcite (often Mn-bearing) observed with the SEM during this study, interpreted to have formed during hydrothermal processes, typically exhibits solution features.

\subsection{Isotopic Results for Calcite Samples}

Stable isotope analyses $\left(\delta^{13} \mathrm{C}\right.$ and $\left.\delta^{18} \mathrm{O}\right)$ provide insight into the origin and temperature of formation of fracture-lining calcite, and are useful in assessing water-rock interaction processes for geochemical models. Table 3 summarizes the results of analyses performed for this study, and includes estimates of calcite formation temperatures. In general, the calcite stable isotope data show a weak negative correlation between $\delta^{18} \mathrm{O}$ and $\delta^{13} \mathrm{C}$ (Figure 2), and can be broadly separated into two groups, with $\delta^{18} \mathrm{O}=+9 \%$ as an approximate dividing line.

Calcite samples with $\delta^{18} \mathrm{O}$ values less than $+9 \%$ o have $\delta^{13} \mathrm{C}$ values between $+1.8 \%$ and +4.6\% . This group includes samples from ER-EC-1, ER-EC-5, ER-EC-6, and one sample from ER-EC-4 (see Figure 2). With the exception of ER-EC-4, these wells are located west of the Thirsty Canyon fault [Grauch et al., 1997] within the caldera moat around Timber Mountain. Although this group includes many of the deepest samples, the sample with the lowest $\delta^{18} \mathrm{O}$ value $(+0.3 \%$ ) is from a relatively shallow depth [ER-EC-5 $(1190-1210 \mathrm{ft})]$. In general, low $\delta^{18} \mathrm{O}$ values are indicative of calcite that formed at elevated temperatures (see section 4.2.1). The relatively high $\delta^{13} \mathrm{C}$ values imply the calcite precipitated from groundwater that equilibrated with the Paleozoic carbonate aquifer. Paleozoic carbonate rocks in southern Nevada typically have $\delta^{13} \mathrm{C}$ values between 0 and $+4 \%$ o [cf. Thomas et al., 1996, Table 17]. Calcite veins with similarly low $\delta^{18} \mathrm{O}$ and high $\delta^{13} \mathrm{C}$ values were previously noted in samples from the saturated zone at Yucca Mountain and Pahute Mesa [Whelan and Stuckless, 1992; Rose et al., 1999].

The calcite samples with $\delta^{18} \mathrm{O}$ values greater than $+9 \%$ o have $\delta^{13} \mathrm{C}$ values between -7.5 and $+1.6 \%$ o (Figure 2). The $\delta^{18} \mathrm{O}$ values for these samples imply formation at moderate to low temperatures. The range in $\delta^{13} \mathrm{C}$ values probably reflects carbon originating from both pedogenic (soil zone) and carbonate bedrock sources. Pedogenic carbonate forms in arid environments during mineral weathering processes involving soil $\mathrm{CO}_{2}$ [Salomons and Mook, 1986]. The carbon isotopic composition of the pedogenic carbonate is determined by the soil $\mathrm{CO}_{2}$ gas composition, and reflects the type of vegetation in the area [Cerling, 1984]. Quade et al. [1989] noted that pedogenic carbonate $\delta^{13} \mathrm{C}$ values decrease systematically with increasing elevation in southern Nevada, ranging from about -1 to $-7 \%$ at elevations between 1000 and $2000 \mathrm{~m}$. Calcite in the deep unsaturated zone is thought to accumulate slowly over time as dissolved inorganic carbon in percolating waters carries soil carbonate down along fractures in the rock [Whelan and Stuckless, 1992]. Although a majority of the samples analyzed during this study were collected 
below the present-day water table, the $\delta^{13} \mathrm{C}$ values for some samples clearly reflect a pedogenic carbon source.

Figure 3 is a $\delta^{13} \mathrm{C}-\delta^{18} \mathrm{O}$ plot that compares the calcite samples analyzed during this study with calcite data for cores from six additional boreholes on Pahute Mesa [data from Rose et al., 1999]. The pattern of variation is similar for both data sets. In particular, all of the "low" $\delta^{18} \mathrm{O}$ samples $\left(<+9 \%\right.$ ) have $\delta^{13} \mathrm{C}$ values that reflect an origin from carbonate bedrock. This suggests that major structural features in this region extend to sufficient depths to allow thermally buoyant groundwater that has interacted with Paleozoic carbonate aquifer materials to ascend into the volcanic section.

\subsubsection{Temperature estimates from calcite $\delta^{18} \mathrm{O}$ data}

In general, the WPM-OV calcite samples have $\delta^{18} \mathrm{O}$ values that decrease with increasing depth, in response to increasing temperature (Figure 4). Calcite $\delta^{18} \mathrm{O}$ values can be used to estimate the temperature at which a calcite sample formed if the $\delta^{18} \mathrm{O}$ value of the source water is known, or can be reliably estimated. Calcite formation temperatures were calculated using the calcite-water fractionation equation developed by O'Neil and others [1969]. Modern groundwater from the deep volcanic aquifers in the WPM-OV region has a $\delta^{18} \mathrm{O}$ value near $-15 \%$ [Rose et al., 1997; Thomas et al., 1999]. For this study, we will assume that saturated zone calcites formed from water of this composition, although the actual value is likely to have varied over time. Calcite that originally formed in the unsaturated zone was precipitated from meteoric waters percolating down from the surface. The average $\delta^{18} \mathrm{O}$ value of modern meteoric water at the Nevada Test Site varies from around $-12.5 \%$ at $7200 \mathrm{ft}$ to $-9.5 \%$ at $3150 \mathrm{ft}$ [Ingraham et al., 1991]. Due to uncertainties in assumed $\delta^{18} \mathrm{O}_{\text {water }}$ values, we have calculated calcite-water equilibrium temperatures using three different $\delta^{18} \mathrm{O}_{\text {water }}$ compositions: $-15,-12.5$ and $-10 \%$. The results are reported in Table 3.

At depths less than $1000 \mathrm{ft}$, estimated temperatures range from 6 to $35^{\circ} \mathrm{C}$ for $\delta^{18} \mathrm{O}_{\text {water }}=$ $-12.5 \%$, and from 16 to $49^{\circ} \mathrm{C}$ for $\delta^{18} \mathrm{O}_{\text {water }}=-10 \%$. Unrealistically low temperatures for some samples indicate calcite samples that formed from relatively ${ }^{18} \mathrm{O}$-enriched waters. For example, a reasonable temperature estimate for the shallow sample from ER-OV-3a

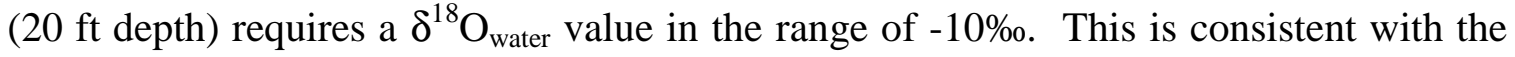
expected mean value for precipitation at the land-surface elevation of this well (3844 ft) and implies the calcite may have formed from local infiltration. A possible alternative explanation for the origin of this sample is discussed in section 4.2.3.

At depths below $1000 \mathrm{ft}$, estimated calcite temperatures range from 15 to $116^{\circ} \mathrm{C}$ for $\delta^{18} \mathrm{O}_{\text {water }}=-15 \%$ o, and from 27 to $146^{\circ} \mathrm{C}$ for $\delta^{18} \mathrm{O}_{\text {water }}=-12.5 \%$. It is notable that calcite samples from comparable depths in different wells may show large differences in temperature. For example, calcite samples that were each taken from 1200 ft depth in two different wells (ER-EC-5 and ER-EC-7) have estimated temperatures of 116 and 
$21^{\circ} \mathrm{C}$ respectively (for $\delta^{18} \mathrm{O}_{\text {water }}=-15 \%$ ). Calcite samples from a single borehole may also show isotopic variations that do not reflect a simple increase in temperature with depth. As noted above, the calcite vein temperature for ER-EC-5 (1190-1210 ft) was estimated to be $116^{\circ} \mathrm{C}$ whereas two deeper samples from the same borehole have estimated temperatures near $60^{\circ} \mathrm{C}$ (see Table 3). Heterogeneous variations in calcite $\delta^{18} \mathrm{O}$ values with depth imply multiple, spatially discrete episodes of deposition at different temperatures.

Figure 5 is a plot of $\delta^{18} \mathrm{O}$ versus depth that compares the WPM-OV calcite samples from this study to calcite samples previously collected from wells on Pahute Mesa [Rose et al., 1999]. Note the expanded depth scale relative to Figure 4. Figure 5 includes a set of curves that represent the $\delta^{18} \mathrm{O}$ values of calcite in equilibrium with $-15 \%$ o groundwater along geothermal gradients of $22,34,45,60$ and $75^{\circ} \mathrm{C} / \mathrm{km}$, assuming a surface temperature of $15^{\circ} \mathrm{C}$. Modern geothermal gradients estimated for this region from borehole measurements at Yucca Mountain range from 34 to $45^{\circ} \mathrm{C} / \mathrm{km}$ [Sass et al., 1980; Szabo and Kyser, 1990].

In general, both data sets represented in Figure 5 show similar variations in $\delta^{18} \mathrm{O}$. At depths less than $\sim 2000 \mathrm{ft}$, the data show a wide range in $\delta^{18} \mathrm{O}$ values, plotting along a trend that obliquely transects the geothermal gradient curves. Calcite samples with $\delta^{18} \mathrm{O}$ values greater than about $+15 \%$ o probably formed from ${ }^{18} \mathrm{O}$-enriched local recharge, and hence would lie along a different set of geotherms than are shown in Figure 5. For example, geotherms calculated using $\delta^{18} \mathrm{O}_{\text {water }}=-12.5 \%$ would be shifted to the right of the set of curves shown in Figure 5.

Samples with $\delta^{18} \mathrm{O}$ values between about +10 and $+15 \%$ o plot in the range expected for calcite precipitated from modern $(-15 \%)$ groundwater at geothermal gradients typical of the region. A number of samples with $\delta^{18} \mathrm{O}$ values less than $+10 \%$ lie along geothermal gradients that are elevated relative to the modern regional gradient. The latter group probably includes calcite that was deposited by localized hydrothermal fluids, possibly associated with episodes of caldera-forming silicic volcanism. It is also notable that two deep samples from the FY98 data set plot along a depressed geothermal gradient of between 22 to $28^{\circ} \mathrm{C} / \mathrm{km}$ (Rose et al., 1999). These data are consistent with the deep circulation of cool groundwater at a rate that can, at least locally, overcome the modern geothermal gradient. A similar case can be made for a calcite sample from well ER-EC-4 (2210-2220 ft), which plots below the main data group in Figure 4.

\subsubsection{Variations in calcite morphology with vein temperature}

A general correlation was observed between the physical appearance of the secondary calcite and the depositional temperatures estimated from $\delta^{18} \mathrm{O}$ data. Low temperature calcite $\left(<30^{\circ} \mathrm{C}\right)$ commonly consists of sharp, transparent euhedral crystals, up to nearly 1 
$\mathrm{cm}$ in size. In some cases the crystals show weak etching that implies dissolution, although many of the crystals are very sharp and may have formed relatively recently. This type of calcite is especially prevalent in ER-EC-4, but was also observed in ER-EC7. In contrast, higher temperature calcite $\left(>60^{\circ} \mathrm{C}\right)$ is characterized by opaque white polycrystalline veins consisting of densely intergrown crystals. Individual cleavage faces rarely exceed $2 \mathrm{~mm}$. This higher temperature calcite is commonly associated with $\mathrm{Mn}-$ oxides, which sometimes occur as discrete phases within the calcite vein. Much of the high temperature calcite shows evidence of partial dissolution. This type of calcite is common in the ER-EC-1, ER-EC-5 and ER-EC-6 wells, all of which are located within the moat of the Timber Mountain caldera. These observations may provide some general guidance regarding subregions within the groundwater flow system where calcite is dissolving or precipitating. In particular, it is of interest to determine whether a correlation exists between the groundwater calcite saturation index and the presence of a particular type of calcite.

\subsubsection{Radiocarbon data}

One radiocarbon measurement was performed during this study on a tuffaceous alluvium sample from the $20 \mathrm{ft}$ depth interval in well ER-OV-3a. Calcite is present as a minor secondary phase in the fine-grained matrix of the sample. The calcite has a ${ }^{14} \mathrm{C}$ activity of 4.0 percent modern carbon, yielding a 26,650-year age. As noted in the preceding section, the $\delta^{18} \mathrm{O}$ value for this sample suggests it may have formed at low temperatures from local infiltration of ${ }^{18} \mathrm{O}$-enriched water. In contrast, the REE pattern for this sample suggests it may have precipitated from groundwater upwelling from the saturated zone. It is plausible that the calcite precipitated from regional groundwater at a time when the water table was elevated relative to its current level. The present depth to water in ER-OV-3a is $56.6 \mathrm{ft}$ [Robledo et al., 1998]. Groundwater evaporation prior to calcite deposition would account for the relatively heavy calcite $\delta^{18} \mathrm{O}$ value. This hypothesis is consistent with the relatively old ${ }^{14} \mathrm{C}$ age of the calcite sample.

Although four additional samples were acquired from ER-OV wells for the purpose of radiocarbon analysis, none of the samples contained a sufficient amount of calcite for analysis. Radiocarbon analyses of deeper vein calcites were not attempted because the results of a previous study [Rose et al., 1999] suggested that the deep calcites are characteristically devoid of ${ }^{14} \mathrm{C}$.

\subsection{Results of Rare Earth Element Analyses of Secondary Calcite}

Recent studies have demonstrated that secondary calcite from volcanic rocks at the NTS exhibit distinct chemical and isotopic signatures that correlate to different zones in the hydrostratigraphic column [Peterman et al., 1992; Whelan and Stuckless, 1992; Vaniman, 
1993, 1994; Vaniman and Chipera, 1996; Paces et al., 1996; Denniston et al., 1997; Rose et al., 1999; Zhou et al., 1999b]. The preceding section of this report showed that calcite stable isotope values generally reflect the origin of the groundwater from which the mineral forms, as well as its depositional temperature. Rare earth element (REE) concentrations in secondary calcite can provide additional insight into the origin of the fluid from which a calcite forms. In addition, the data may potentially be used in conjunction with groundwater REE data to evaluate water-rock interaction processes.

The results of REE analyses for 7 secondary calcite samples are presented in Table 4. Concentrations are reported in units of parts per million (ppm). Analytical errors were assigned using standard statistical methods of error propagation, and are reported as $1 \sigma$ standard deviations (std. dev.). REE abundances are commonly evaluated after normalizing [e.g. Evensen et al., 1978] the measured REE concentrations to the concentration in an average chondritic meteorite (in the case of igneous rocks or magmatic processes) or average shale (in the case of sedimentary rocks or weathering processes). This step smooths out the atomic number dependent variations in the absolute abundances of the REE and facilitates the assessment of the processes under consideration. Since the geologic environment recorded in the samples from WPM-OV drill samples is complex and reflects overlapping hydrothermal and weathering processes, both chondrite- and shale-normalized REE plots are presented. Chondritenormalized REE patterns for the calcite samples are shown in Figure 6 . Shalenormalized REE patterns for the same samples are shown in Figure 7.

With two exceptions, the REE always occur in the 3+ valence state in nature. Since their outer electron structures are so similar, the REE show very similar chemical properties, and generally occur as a group in nature [Krauskopf, 1979]. However, the effective ionic radius for the $3+$ oxidation state progressively decreases from $1.03 \AA$ in $\mathrm{La}^{3+}$ to $0.86 \AA$ in $\mathrm{Lu}^{3+}$ [for sixfold coordination; data from Shannon, 1976]. As a result, there is a tendency for the light REE (LREE; La through Nd) to be partitioned from the heavy REE (HREE; Er through $\mathrm{Lu})$ during mineral growth from a liquid. In the case of calcite $\left(\mathrm{CaCO}_{3}\right)$, the $\mathrm{Ca}^{2+}$ ions are in sixfold coordination with oxygens of the $\left(\mathrm{CO}_{3}\right)^{2-}$ groups, with an effective ionic radius of $1.00 \AA$. This is similar to the ionic radius of the LREE, implying the LREE may be preferentially incorporated into the calcite crystal structure relative to the HREE, in the absence of other competing effects. Anomalous variations in the distribution of $\mathrm{Ce}$ and $\mathrm{Eu}$ reflect changes in the oxidation state of these elements $\left(\mathrm{Ce}^{3+}\right.$ to $\mathrm{Ce}^{4+}$ and $\mathrm{Eu}^{2+}$ to $\mathrm{Eu}^{3+}$ ). Hence, these elements provide useful indicators of redox conditions at the time of mineral deposition.

\subsubsection{Chondrite-normalized REE distribution}

The WPM-OV calcite samples all exhibit REE concentration enrichments relative to chondrite (Sample/Chondrite > 1), and are enriched in the LREE relative to the HREE on 
a chondrite-normalized plot. Four types of REE patterns are observed in the chondritenormalized plot shown in Figure 6.

(1) Type (1c) pattern:

ER-EC-4a (1150-1160 ft)

ER-EC-8 (1850-1870 ft)

Characterized by moderate to strong LREE enrichment, with negative $\mathrm{Ce}$ and $\mathrm{Eu}$ anomalies. This pattern is typical of near-surface (pedogenic) processes [Denniston et al., 1997; Zhou et al., 1999b], and is observed in samples from the upper saturated zone. The REE patterns suggest these samples were precipitated from downward-flowing waters originating from the unsaturated zone. The calcite $\delta^{18} \mathrm{O}$ values for these samples are generally consistent with this interpretation. The negative $\mathrm{Ce}$ and $\mathrm{Eu}$ anomalies result from the decreased solubility that accompanies the oxidation of $\mathrm{Ce}$ and $\mathrm{Eu}$ in a shallow depositional environment [Vaniman and Chipera, 1996].

(2) Type (2c) pattern:

ER-30-1 (750-760 ft)

ER-OV-3a $(20 \mathrm{ft})$

Defined by strong LREE enrichment accompanied by moderate negative Eu anomalies. This pattern is associated with samples from both the saturated zone [ER-30-1 (750-760 $\mathrm{ft}$ )] and the unsaturated zone [ER-OV-3a $(20 \mathrm{ft})$ ], and is very similar to the REE patterns for felsic volcanic rocks and perched volcanic groundwater at the Nevada Test Site [Johannesson et al., 1997, 2000; Zhou et al., 1999a]. Although the calcite sample from ER-OV-3a $(20 \mathrm{ft})$ is from the shallow unsaturated zone, the geochemical data for this sample suggests it may have originated from upwelling groundwater (see section 4.2.3).

(3) Type (3c) pattern:

ER-18-2 (2050-2080 ft)

Moderate LREE enrichment with a negative $\mathrm{Ce}$ anomaly and a strong positive $\mathrm{Eu}$ anomaly characterize the type (3c) pattern, observed in one sample from the saturated zone. The positive Eu anomaly is reminiscent of those reported for hydrothermal fluids from mid-ocean ridges [Klinkhammer et al., 1994], and may imply a hydrothermal origin

for this sample. However, the $\delta^{18} \mathrm{O}$ value for this sample suggests only a moderate depositional temperature $\left(43^{\circ} \mathrm{C}\right)$. Hence, if this sample is of hydrothermal origin, it was probably deposited in a cooler part of the geothermal system. The calcite $\delta^{13} \mathrm{C}$ value $(-0.9 \%$ o ) for this sample is within the accepted range of values for a deep carbon source originating from Paleozoic bedrock.

(4) Type (4c) pattern:

ER-EC-4b (2210-2220 ft)

ER-EC-6 (3420-3440 ft)

The type (4c) pattern is defined by a weak LREE enrichment and weak to moderate negative $\mathrm{Ce}$ and $\mathrm{Eu}$ anomalies. It is notable that the two samples displaying this type of 
pattern have an approximate order of magnitude difference in their REE concentrations. The low concentration sample [ER-EC-4b $(2210-2220 \mathrm{ft})$ ] has a $\delta^{18} \mathrm{O}$ value consistent with low temperature deposition (minimum $17^{\circ} \mathrm{C}$ ) and a $\delta^{13} \mathrm{C}$ value that indicates a pedogenic source. In contrast, the high REE concentration sample [ER-EC-6 (3420-3440 $\mathrm{ft}$ )] was deposited at high temperature (minimum $108^{\circ} \mathrm{C}$ ) from groundwater that equilibrated with Paleozoic carbonate rocks. These results indicate that the simple evaluation of REE patterns is not always sufficient for differentiating between depositional processes.

\subsubsection{Shale-normalized REE distribution}

As shown on the shale-normalized plot (Figure 7), five of the seven samples analyzed exhibit equivalent order of magnitude REE concentrations as shale (sample/shale $\cong 1$ ). The two samples from ER-EC-4 are depleted relative to shale (sample/shale $<1$ ) and exhibit low REE concentrations. The samples are subdivided into three types on the basis of REE abundance and distribution patterns.

(1) Type (1s) pattern:

ER-EC-4a (1150-1160 ft)

ER-EC-4b (2210-2220 ft)

This pattern is characterized by a modest HREE-enrichment, with REE concentrations significantly less than shale. The strong negative Ce anomaly in ER-EC-4a is again consistent with oxidation of $\mathrm{Ce}^{3+}$ to $\mathrm{Ce}^{4+}$ in the near-surface environment. $\delta^{18} \mathrm{O}$ results for both samples indicate low temperature deposition, and $\delta^{13} \mathrm{C}$ results suggest a pedogenic carbon source.

(2) Type (2s) pattern:

ER-EC-8 (1850-1860 ft)

ER-30-1 (750-760 ft)

ER-OV-3a $(20 \mathrm{ft})$

Type (2s) patterns exhibit REE concentrations comparable to average shale (sample/shale $\cong 1$ ), and are slightly enriched in LREE. The REE patterns for ER-30-1 and ER-OV-3a are similar to one another on both the chondrite- and shale-normalized plots, and are interpreted to represent a signature derived from the host volcanic rocks. In contrast, EREC-8 exhibits strong negative $\mathrm{Ce}$ and $\mathrm{Eu}$ anomalies indicative of oxidizing conditions. The pronounced Ce anomaly for ER-EC-8 is similar to that of ER-EC-4a. Comparable Ce anomalies are observed for ER-EC-4a and ER-EC-8 on the chondrite-normalized plot [type (1c) pattern].

(3) Type (3s) pattern:

ER-EC-6 (3420-3440 ft)

ER-18-2 (2050-2080 ft)

The type (3s) pattern is defined by REE concentrations similar to average shale (sample/shale $\cong 1$ ), but with a slight to moderate degree of HREE enrichment. This 
implies that LREE solubilities were enhanced during deposition of these samples. This pattern is observed in saturated zone samples formed at moderate to high temperatures. Both samples of this type show slight negative Ce anomalies. In addition, ER-18-2 shows a positive Eu anomaly, as was observed on the chondrite-normalized plot [type (3c) pattern].

\subsubsection{Discussion of REE results}

The secondary calcite samples from the WPM-OV wells all exhibit some degree of REE fractionation. This suggests that solution characteristics at the time of deposition played an important role in the REE composition of the calcite being deposited on fractures. In general, the calcites are strongly enriched in REE relative to chondrite (Sample/Chondrite >> 1) and exhibit REE concentrations comparable to average shale. LREE enrichments are generally observed for all samples on the chondrite-normalized plot (Figure 6). However, samples exhibiting modest LREE enrichments on the chondrite-normalized plot show weak to moderate HREE enrichments on the shale-normalized plot (Figure 7). This is due to differences in the relative abundances of LREE vs. HREE for the average chondrite and shale compositions.

LREE enrichments (relative to HREE) are observed in both Figures 6 and 7 for three samples: ER-EC-8 (1850-1870'), ER-30-1 (750-760'), and ER-OV-3a (20'). The latter two samples were interpreted to have REE patterns similar to that of the host volcanic rocks. It is notable, however, that mineral/solution partitioning of REE may also influence the LREE to HREE distribution. Preferential ion substitution of LREE for $\mathrm{Ca}^{2+}$ in the calcite structure was previously noted. In addition, Wood [1990] showed that HREE solubility is enhanced relative to LREE in the presence of carbonate species at elevated $\mathrm{pH}$ values.

As noted above, moderate to weak LREE enrichments in Figure 6 correlate with HREE enrichments in Figure 7. This pattern is observed in four samples: ER-EC-4a (11501160'), ER-EC-4b (2210-2220'), ER-EC-6 (3420-3440'), and ER-18-2 (2050-2080'). Wood [1990] noted that the solubility of LREE is enhanced relative to HREE in the presence of elevated dissolved sulfate concentrations. Sulfate has been identified as one of the dominant anions in groundwater from the volcanic aquifers of Pahute Mesa [e.g. Thomas et al., 1999; Chapman and Lyles, 1993]. However, bicarbonate ion concentrations always exceed those of sulfate, and the extent to which these competing ion effects influence REE solubilities remains an open question.

Anomalous variations in the distribution of $\mathrm{Ce}$ and $\mathrm{Eu}$ are observed for many of the samples, and are related to redox conditions at the time of calcite deposition. In general, the most pronounced $\mathrm{Ce}$ and Eu depletions are observed in samples from shallow saturated zone fractures [e.g. ER-EC-4a (1150-1160') and ER-EC-8 (1850-1870')]. This is consistent with oxidation being a more influential process in the near surface 
environment. However, some "near-surface" samples show relatively weak redox anomalies [e.g. ER-OV-3a (20') and ER-30-1 (750-760')], indicating that proximity to the weathering zone is not the sole factor influencing redox conditions.

Calcite deposition temperatures inferred from $\delta^{18} \mathrm{O}$ results do not correlate with LREE/HREE enrichments, nor do they correlate with the presence of $\mathrm{Ce}$ and $\mathrm{Eu}$ anomalies. The highest temperature sample [ER-EC-6 (3420-3440')] does show the highest REE concentrations, implying enhanced solubilities at elevated temperatures. As previously noted, the positive Eu anomaly in the ER-18-2 sample may be indicative of hydrothermal conditions. Correlations between calcite $\delta^{13} \mathrm{C}$ results and REE patterns were not observed.

In general, it is not yet possible to clearly link specific REE patterns and concentrations to specific processes or environments. A combination of factors influence the observed patterns, including groundwater chemistry, host rock REE abundances, redox conditions, temperature, and stratigraphic position. The limited data obtained during this study does not permit the relative importance of each factor to be evaluated. However, the fact that significant variations in REE fractionation and total REE concentrations exist suggests that additional analytical work may help link certain REE patterns to specific processes. 


\subsection{Discussion and Conclusions}

Prior to the development of the ER-EC wells, little was known about the subsurface geology, hydrostratigraphy, and groundwater geochemistry of the region between Pahute Mesa and Oasis Valley. The results of this study provide insight into both the types of minerals that occur along fractures in the WPM-OV region, as well as the processes responsible for their deposition. These data can be coupled with the results of on-going hydrogeologic investigations and groundwater characterization studies to yield more accurate conceptual models and evaluations of groundwater solute transport for this region.

Fracture-lining mineral assemblages are often very different from those found in the surrounding rock matrix. The most common fracture-lining minerals observed in the study area include calcite, chalcedony, Fe- and Mn-oxyhydroxides, mixed illite/smectite (clays), and zeolites. Several of these phases are readily dissolved or precipitated depending on the saturation state of the mineral relative to the ambient groundwater. In addition, the clays, oxides and zeolites all exhibit relatively high sorption capacities, providing substrates for the removal of dissolved constituents from through-going groundwater. Physical evidence for mineral dissolution was noted in Table 1 and Appendix 1 of this report, providing specific constraints on mineral reaction processes at various points within the groundwater flow system.

Fracture-lining minerals on 25 samples from the welded tuff aquifers (predominantly Timber Mountain and Paintbrush Tuffs) are characterized by abundant calcite, chalcedony, Fe- and Mn-oxyhydroxides, and mixed illite/smectite. Minerals observed in lesser amounts include quartz, zeolite minerals (chabazite, phillipsite), dolomite, apatite, barite, scheelite, and cuprotungstite. A smaller set of 8 samples from the rhyolitic lava flow aquifers contain chalcedony, mixed illite/smectite, Fe- and Mn-oxyhydroxides, and less abundant calcite, quartz and K-feldspar. Zeolite minerals (including clinoptilolite, mordenite, and levyne) are most prevalent within the Trachyte of Ribbon Cliff (Thirsty Canyon Group), where they occur with chalcedony, calcite, and clay minerals. Of special note is the base metal mineralization $(\mathrm{Pb}, \mathrm{Cu}, \mathrm{Zn}, \mathrm{Fe}, \mathrm{Mn})$ associated with chalcedony and clay minerals in well UE-29a \#2.

Secondary calcite samples exhibit a range in $\delta^{13} \mathrm{C}$ and $\delta^{18} \mathrm{O}$ values that reflect both lowtemperature deposition of pedogenic carbonate at shallow levels, and moderate- to hightemperature deposition of remobilized Paleozoic carbonate in the deep saturated zone. Calcite $\delta^{18} \mathrm{O}$ data reveals a number of samples were deposited under hydrothermal conditions, sometimes at relatively shallow depths. For example, calcite from only 1200 $\mathrm{ft}$ depth in ER-EC-5 formed at a minimum temperature of $116^{\circ} \mathrm{C}$. Fracture-lining minerals from $1440 \mathrm{ft}$ depth in the same borehole include barite $\left(\mathrm{BaSO}_{4}\right)$ and scheelite $\left(\mathrm{CaWO}_{4}\right)$, both of which commonly form under hydrothermal conditions. Hydrothermal 
calcite is found principally within the moat of the Timber Mountain caldera, particularly in wells ER-EC-1, -5 and -6 . Most other calcite samples have ${ }^{18} \mathrm{O}$-temperatures that are consistent with the modern geothermal gradient for this region. One sample from this study [ER-EC-4 (2210-2220 ft)] and two additional samples from Rose et al [1999] have $\delta^{18} \mathrm{O}$ values that indicate precipitation at temperatures below the regional geothermal gradient, suggesting locally deep circulation of cooler groundwater.

A radiocarbon analysis of a single sample from shallow depth (20 ft) in well ER-OV-3a yielded a ${ }^{14} \mathrm{C}$ age of 26,650 years. The results of stable isotope and REE analyses for this sample suggest the calcite may have precipitated from evaporating regional groundwater at a time when the water table was elevated relative to its current position.

Secondary calcite samples are strongly enriched in REE relative to average chondritic compositions (sample/chondrite > 1), and have REE concentrations similar to average shale compositions (sample/shale $\sim 1$ ). The observed concentrations are consistent with the tendency for REE to be enriched in the continental crust. The calcite samples all exhibit some degree of LREE/HREE fractionation. The partitioning of LREE relative to $\mathrm{HREE}$ is influenced by water chemistry (e.g. complexing with $\mathrm{HCO}_{3}{ }^{-}$and $\mathrm{SO}_{4}{ }^{2-}$ ions [Wood, 1990]) and by the preferential substitution of LREE for $\mathrm{Ca}^{2+}$ in the calcite crystal lattice. Anomalous variations in $\mathrm{Ce}$ and $\mathrm{Eu}$ concentrations are related to changes in oxidation state $\left(\mathrm{Ce}^{3+}\right.$ to $\mathrm{Ce}^{4+}$ and $\mathrm{Eu}^{2+}$ to $\left.\mathrm{Eu}^{3+}\right)$, and are useful indicators of redox conditions at the time of mineral deposition.

Observed REE patterns reflect the influence of pedogenic processes, precipitation from regional groundwater, and hydrothermal deposition. It is difficult to unequivocally link specific patterns to specific processes, due to the relatively small REE data set. However, a few correlations are notable. Strong negative $\mathrm{Ce}$ and $\mathrm{Eu}$ anomalies are most pronounced in samples from relatively shallow depths, but are not observed in all "shallow" samples. These anomalies indicate strongly oxidizing conditions during calcite deposition. The strongest LREE enrichments are also observed in relatively shallow samples. A high temperature sample from the ER-EC-6 well (3420-3440') contains the highest concentrations of REE, suggesting REE solubility may be enhanced at elevated temperatures. Future investigations of REE patterns in calcite samples should continue to focus on linking the observed patterns to other physiochemical parameters (e.g. depositional temperature, host rock REE concentrations, and water chemistry). In addition, comparative studies with groundwater REE data are needed to determine the applicability of these data for constraining reactive flow and transport geochemical models. 


\subsection{References Cited}

Blankennagel, R.K., and Weir, J.E., Jr. 1973. Geohydrology of the eastern part of Pahute Mesa, Nevada Test Site, Nye County, Nevada. U.S. Geological Survey Professional Paper 712-B, 35 p.

Bowen, S.M., Baca, P.L., Olivas, L.F., Geoffrion, C.G., Thompson, J.L., Miller, C.M., Goishi, W., Esser, B.K., Meadows, J.W., Namboodiri, N., Smith, D.K., and Wild, J.F. 1994. Nevada Test Site Radionuclide Inventory, 1955-1992. Los Alamos National Laboratory, Classified Report, LA-CP-94-0226.

Cerling, T.E. 1984. The stable isotopic composition of modern soil carbonate and its relationship to climate. Earth and Planetary Science Letters, 71, 229-240.

Chapman, J.B., and Lyles, B.F. 1993. Groundwater chemistry at the Nevada Test Site: data and preliminary interpretations. Water Resources Center, Desert Research Institute, Publication No. 45100, Las Vegas, NV, 45 p.

Denniston, R.F., Shearer, C.K., Layne, G.D., and Vaniman, D.T. 1997. SIMS analysis of minor and trace element distributions in fracture calcite from Yucca Mountain, Nevada, USA. Geochimica et Cosmochimica Acta, 61, 1803-1818.

Evensen, N.M., Hamilton, P.J., and O'Nions, R.K. 1978. Rare-earth abundances in chondritic meteorites. Geochimica et Cosmochimica Acta, 42, 1199-1212.

Grauch, V.J.S., Sawyer, D.A., Fridrich, C.J., and Hudson, M.R. 1997. Geophysical interpretations west of and within the northwestern part of the Nevada Test Site. U.S. Geological Survey Open-File Report $97-476,45 \mathrm{p}$.

Ingraham, N.L., Lyles, B.F., Jacobson, R.L., and Hess, J.W. 1991. Stable isotopic study of precipitation and spring discharge in southern Nevada. Journal of Hydrology, 125, 243-258.

IT Corporation. 1998a. Western Pahute Mesa-Oasis Valley Hydrogeologic Investigation Wells Drilling and Completion Criteria. ITLV/13052-049, September 1998.

IT Corporation. 1998b. Summary of Micrographic Analysis of Fracture Coating Phases on Drill Cores from Pahute Mesa, Nevada Test Site. ITLV/13052-050, December 1998.

Johannesson, K.H., Stetzenbach, K.J., Hodge, V.F., Kreamer, D.K., and Zhou, X. 1997. Delineation of ground-water flow systems in the Southern Great Basin using aqueous rare earth element distributions: Ground Water, 35, 807-819.

Johannesson, K.H., Zhou, X., Guo, C., Stetzenbach, K.J., and Hodge, V.F. 2000. Origin of rare earth element signatures in groundwaters of circumneutral $\mathrm{pH}$ from southern Nevada and eastern California, USA. Chemical Geology, 164, 239-257.

Klinkhammer, G.P., Elderfield, H., Edmond, J.M., and Mitra, A. 1994. Geochemical implications of rare earth element patterns in hydrothermal fluids from mid-ocean ridges. Geochimica et Cosmochimica Acta, 58, 5105-5113.

Krauskopf, K.B. 1979. Introduction to Geochemistry, Second Edition. McGraw-Hill, New York, 617 p. 
Laczniak, R.J., Cole, J.C., Sawyer, D.A., and Trudeau, D.A. 1996. Summary of hydrogeologic controls on groundwater flow at the Nevada Test Site, Nye County, Nevada. U.S. Geological Survey WaterResources Investigations Report 96-4109, 59 p.

Maxwell, R.M., Tompson, A.F.B., Rambo, J.T., Carle, S.F., and Pawloski, G.A. 2000. Thermally induced groundwater flow resulting from an underground nuclear test. EOS, Transactions, American Geophysical Union, Spring Meeting, Washington DC, vol. 81, no. 19, p. 245.

McCrea, J.M. 1950. On the isotopic chemistry of carbonates and a paleotemperature scale. Journal of Chemical Physics, 18, 849-857.

O’Neil, J.R., Clayton, R.N., and Mayeda, T.K. 1969. Oxygen isotope fractionation in divalent metal carbonates. Journal of Chemical Physics, 51, 5547-5558.

Paces, J.B., Neymark, L.A., Marshall, B.D., Whelan, J.F., and Peterman, Z.E. 1996. Ages and origins of subsurface secondary minerals in the exploratory studies facilities (ESF). U. S. Geological Survey, Yucca Mountain Project Branch, 1996 Milestone Report 3GQH450M, 55 pp.

Peterman, Z.E., Stuckless, J.S., Marshall, B.D., Mahan, S.A., and Futa, K. 1992. Strontium isotope geochemistry of calcite fracture fillings in deep core, Yucca Mountain, Nevada - A progress report. Proceedings, $3^{\text {rd }}$ International Conference High Level Radioactive Waste Management, p. 1582-1586.

Prothro, L.B. 1999. Preliminary detailed lithologic logs for the 1999 WPM-OV wells. Unpublished report, Bechtel Nevada (written communication).

Quade, J., Cerling, T.E., and Bowman, J.R. 1989. Systematic variations in the carbon and oxygen isotopic composition of pedogenic carbonate along elevation transects in the southern Great Basin, United States. Geological Society of America Bulletin, 101, 464-475.

Reimus, P.W., Ware, S.D., Humphrey, A., Adams, A., Wilson, B., Gonzales, D., Warren, R.G., and Benedict, F.C. 2000. Diffusive and advective transport of ${ }^{3} \mathrm{H},{ }^{14} \mathrm{C}$, and ${ }^{99} \mathrm{Tc}$ in saturated, fractured volcanic rocks from Pahute Mesa, Nevada. LANL draft report. March, 2000.

Renier, S.R., Laczniak, R.J., DeMeo, G.A., Smith, J.L., Nylund, W.E., and Elliott, P.E. 1999. Preliminary estimate of mean annual evapotranspiration, Oasis Valley, Nye County, Nevada. EOS, Transactions, American Geophysical Union, Fall Meeting, San Francisco, vol. 80, no. 46, p. 328.

Robledo, A.R., Ryder, P.L., Fenelon, J.M., and Paillet, F.L. 1998. Geohydrology of monitoring wells drilled in Oasis Valley near Beatty, Nye County, Nevada, 1997. U.S. Geological Survey WaterResources Investigations Report 98-4184, 40 p.

Rose, T.P., Kenneally, J.M., Smith, D.K., Davisson, M.L., Hudson, G.B., and Rego, J.H. 1997. Chemical and isotopic data for groundwater in southern Nevada. Lawrence Livermore National Laboratory, UCRL-ID-128000, $35 \mathrm{p}$.

Rose, T.P., Benedict, F.C., Jr., and Eaton, G.F. 1999. Stable isotope and radiocarbon compositions of secondary calcite from Pahute Mesa, Nevada Test Site. In: D.K. Smith and G.F. Eaton (eds.) Hydrologic Resources Management Program and Underground Test Area FY1998 Progress Report. Lawrence Livermore National Laboratory, UCRL-ID-135170, p. 57-76.

Salomons, W., and Mook, W.G. 1986. Isotope geochemistry of carbonates in the weathering zone. In: P. Fritz and J.Ch. Fontes, eds., Handbook of Environmental Isotope Geochemistry, vol. 2, The Terrestrial Environment, B. Elsevier, Amsterdam, pp. 239-269. 
Sass, J.H., Lachenbruch, A.H., and Mase, C.W. 1980. Analysis of thermal data from drill holes UE25a-3 and UE-25a-1, Calico Hills and Yucca Mountain, Nevada Test Site. U.S. Geological Survey OpenFile Report 80-826, 25 p.

Shannon, R.D. 1976. Revised effective ionic radii and systematic studies of interatomic distances in halides and chalcogenides. Acta Crystallographica, section A, 32, 751-767.

Smith, D.K., Kersting, A.B., Moran, J.E., and Rose, T.P. 2000. Radioisotope tracers as near-field diagnostics of groundwater flow at the Nevada Test Site. EOS, Transactions, American Geophysical Union, Spring Meeting, Washington DC, vol. 81, no. 19, p. 241.

Stuiver, M., and Polach, H. 1977. Reporting of ${ }^{14} \mathrm{C}$ data. Radiocarbon, 19, 355-363.

Szabo, B.J., and Kyser, T.K. 1990. Ages and stable isotope compositions of secondary calcite and opal in drill cores from Tertiary volcanic rocks of the Yucca Mountain area, Nevada. Geological Society of America Bulletin, 102, 1714-1719.

Thomas, J.M., Welch, A.H., and Dettinger, M.D. 1996. Geochemistry and isotope hydrology of representative aquifers in the Great Basin region of Nevada, Utah, and adjacent states. U.S. Geological Survey Professional Paper 1409-C, 100 p.

Thomas, J.M., Benedict, F.C, Jr., Rose, T.P., Hershey, R.L., Paces, J.B., Peterman, Z.E., Farnham, I.M., Johannesson, K.H., Singh, A.K., Stetzenbach, K.J., Hudson, G.B., Kenneally, J.M., Eaton, G.F., and Smith, D.K. 1999. Geochemical and isotopic interpretations of groundwater flow in the Oasis Valley Flow System, southern Nevada. Internal report to U.S. Department of Energy, Nevada Operations Office, Environmental Restoration Division, 30 June 1999.

U.S. Department of Energy. 1994. United States Nuclear Tests, July 1945 through September 1992. U.S. Department of Energy, Nevada Operations Office, DOE/NV-209 (Rev. 14), U.S. Government Printing Office, Washington D.C., 38 p.

U.S. Department of Energy. 1997. Regional Groundwater Flow and Tritium Transport Monitoring and Risk Assessment of the Underground Test Area, Nevada Test Site, Nevada. U.S. Department of Energy, Nevada Operations Office, Environmental Restoration Division, DOE/NV-477, Las Vegas.

Vaniman, D.T. 1993. Calcite deposits in fractures at Yucca Mountain, Nevada. Proceedings, 4th International Conference on High Level Radioactive Waste Management, p. 1935-1939.

Vaniman, D.T. 1994. Calcite deposits in drill cores USW G-2 and USW GU-3/G-3 at Yucca Mountain, Nevada. Los Alamos National Laboratory Report LA-12720-MS.

Vaniman, D.T., and Chipera, S.J. 1996. Paleotransport of lanthanides and strontium recorded in calcite compositions from tuffs at Yucca Mountain, Nevada, USA. Geochimica et Cosmochimica Acta, 60, 4417-4433.

Vogel, J.S., Southon, J.R., and Nelson, D.E. 1987. Catalyst and binder effects in the use of filamentous Graphite for AMS. Nuclear Instruments and Methods in Physics Research, B29, 50-56.

Warren, R.G. 2000. Written communication on stratigraphic classification of cores selected from drillhole UE-29a\#2. January 4, 2000.

Whelan, J.F., and Stuckless, J.S. 1992. Paleohydrologic implications of the stable isotopic composition of secondary calcite within the Tertiary volcanic rocks of Yucca Mountain, Nevada. In: Proceedings of the Third International Conference on High Level Radioactive Waste Management, April 12-16, 1992, 
Las Vegas, NV, pp. 1572-1581.

Wolfsberg, A., Lu, G., McGraw, M., Lichtner, P. 1999. Colloid-facilitated plutonium transport in fractured tuff: model development and sensitivity analysis. EOS, Transactions, American Geophysical Union, Fall Meeting, San Francisco, vol. 80, no. 46, p. 308.

Wood, S.A. 1990. The aqueous geochemistry of the rare earth elements and yttrium. Chemical Geology, $82,159-186$.

Zhou, X., Johannesson, K.H., Stetzenbach, K.J., Guo, C., Farnham, I.M. 1999a. Comparative studies of rare earth elements in groundwaters and aquifer materials from the southern Great Basin. In: Proc. $9^{\text {th }}$ Annual V. M. Goldschmidt Conference, LPI Contribution No. 971, Lunar and Planetary Institute, Houston, p. 340-341.

Zhou, X., Farnham, I.M., Stetzenbach, K.J., Johannesson, K.H., Rose, T.P., Benedict, F.C., and Singh, A.K. 1999b. Rare Earth Elements of Secondary Calcite from Pahute Mesa, Nevada Test Site, USA. EOS, Transactions, American Geophysical Union, Fall Meeting, San Francisco, vol. 80, no. 46, p. 327. 
Figures 


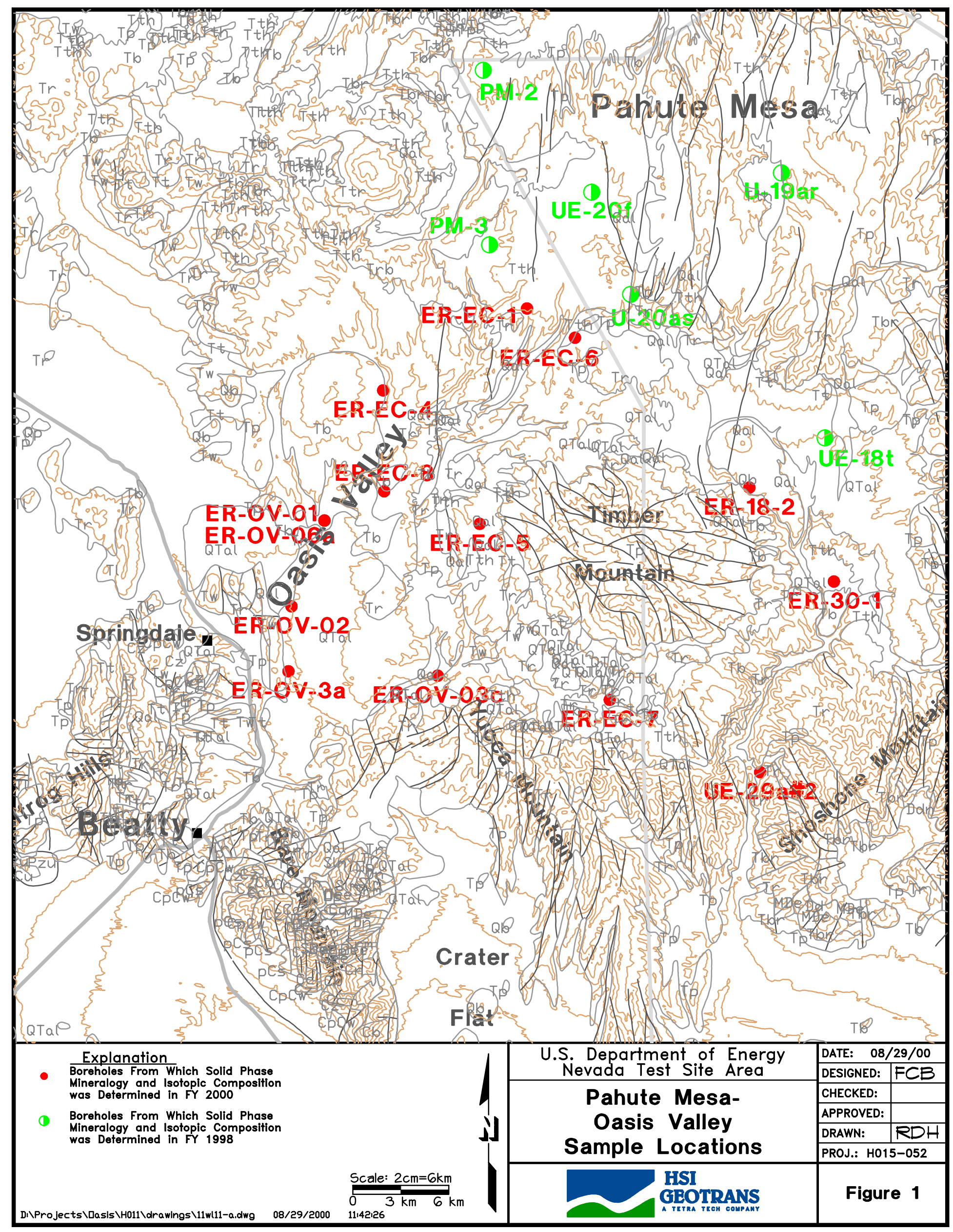




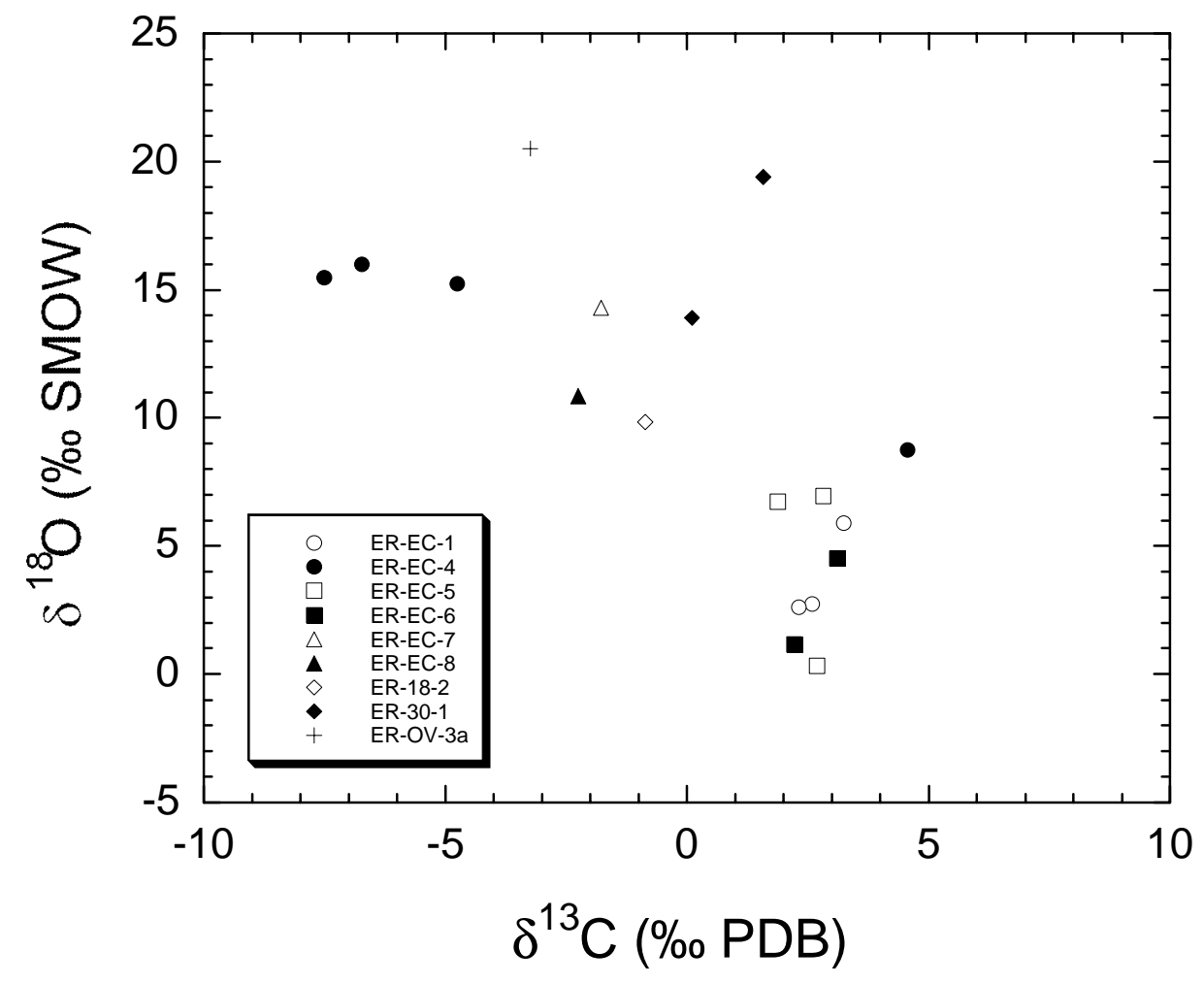

Figure 2. Plot of $\delta^{18} \mathrm{O}$ versus $\delta^{13} \mathrm{C}$ values for WPM-OV calcite samples analyzed during this study. 


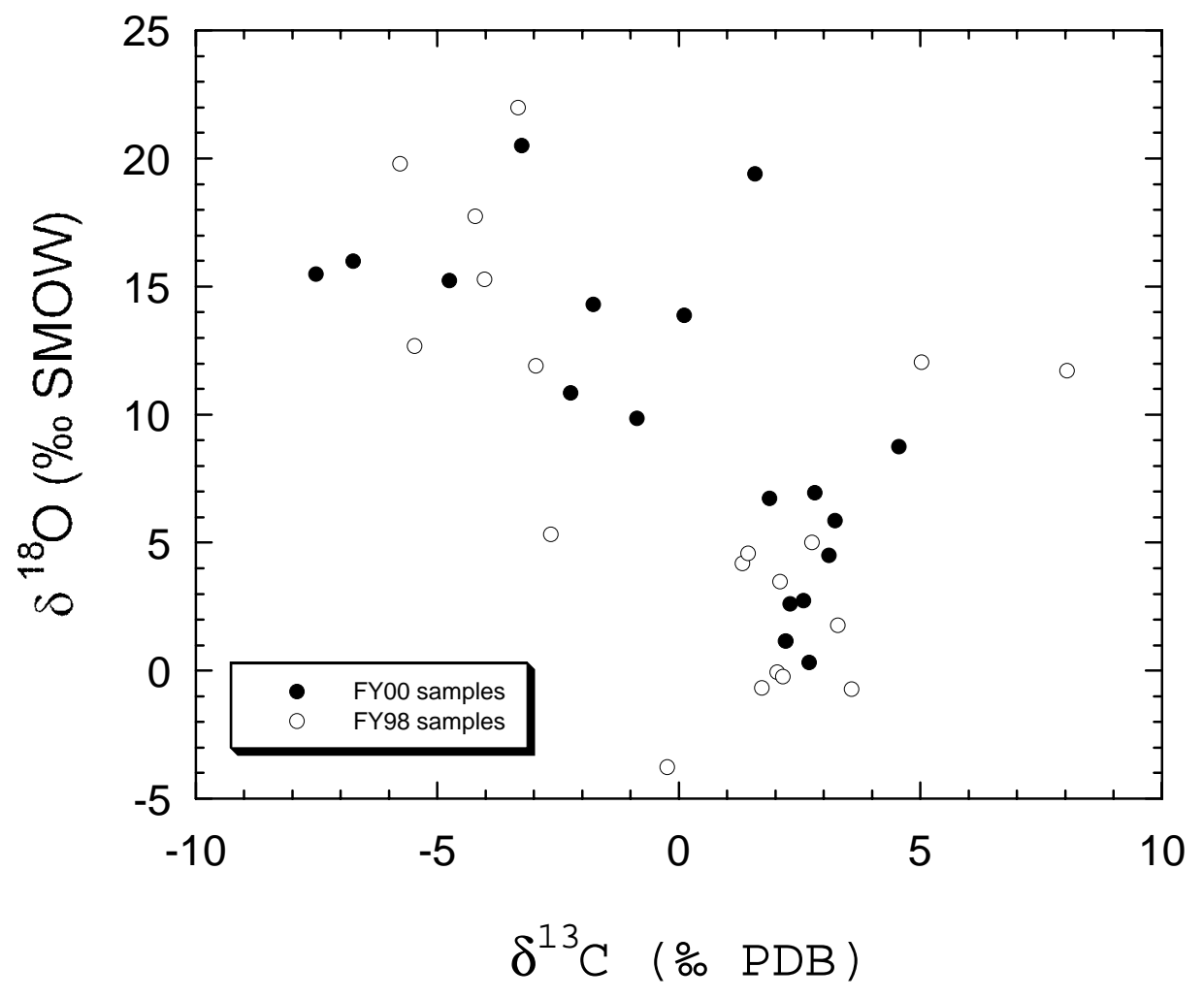

Figure 3. Plot of $\delta^{18} \mathrm{O}$ versus $\delta^{13} \mathrm{C}$ values for the WPM-OV calcite samples (FY00, filled circles) compared with samples from wells on Pahute Mesa (FY98, open circles) previously described by Rose et al. (1999). 


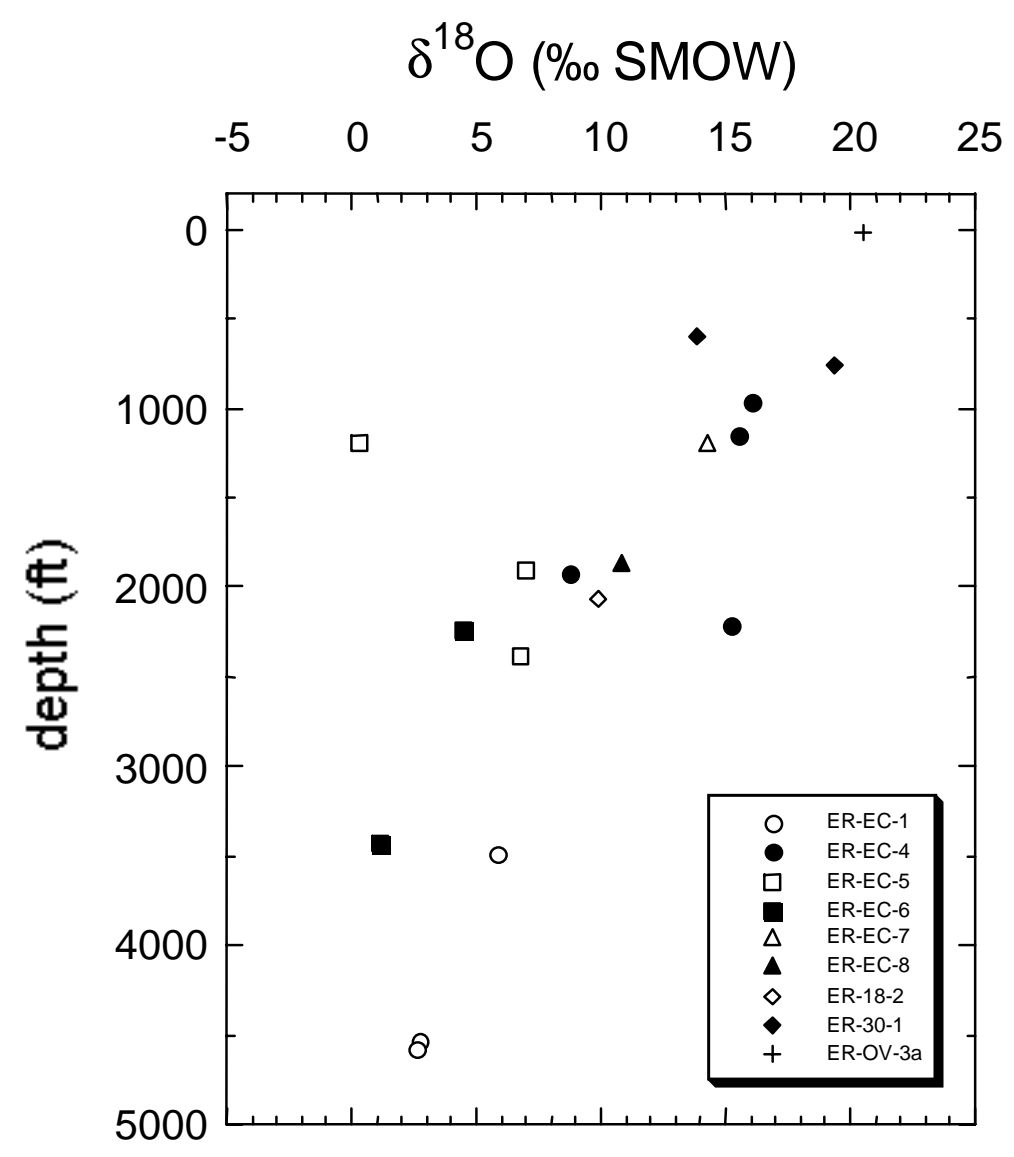

Figure 4. Plot of $\delta^{18} \mathrm{O}$ versus depth for the WPM-OV calcite samples analyzed during this study. 


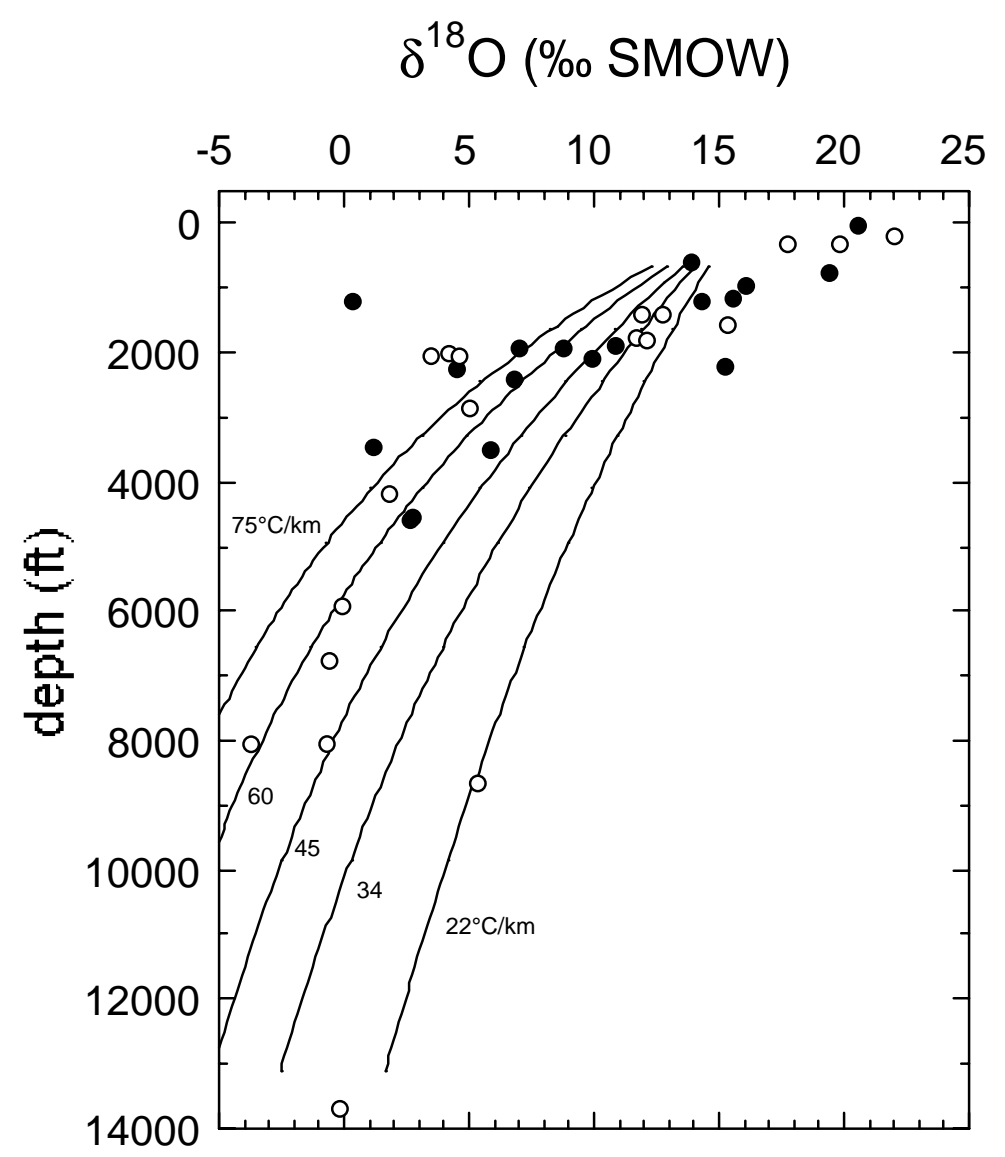

Figure 5. Plot of $\delta^{18} \mathrm{O}$ versus depth comparing the WPM-OV calcite samples from this study (filled circles) with previous data for calcite from wells on Pahute Mesa (open circles; Rose et al., 1999). Curves represent calcite oxygen isotope values in equilibrium with $-15 \%$ o groundwater along geothermal gradients of $22,34,45,60$ and $75^{\circ} \mathrm{C} / \mathrm{km}$. 
Figure 6.

Chondrite-normalized REE Patterns for

Calcite from West Pahute Mesa - Oasis Valley Wells
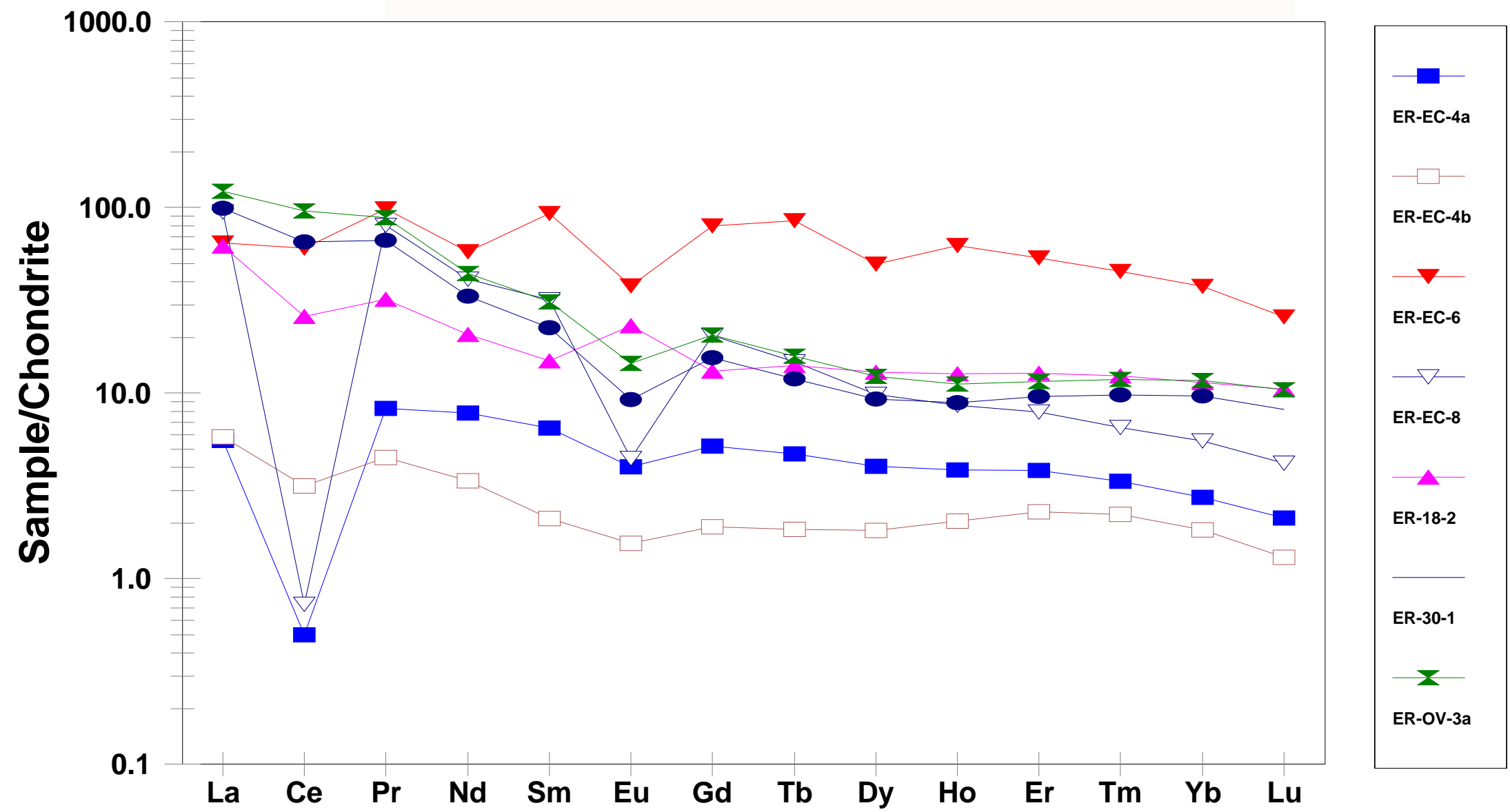
Shale-normalized REE Patterns for
Figure 7. Calcite from Western Pahute Mesa - Oasis Valley Wells

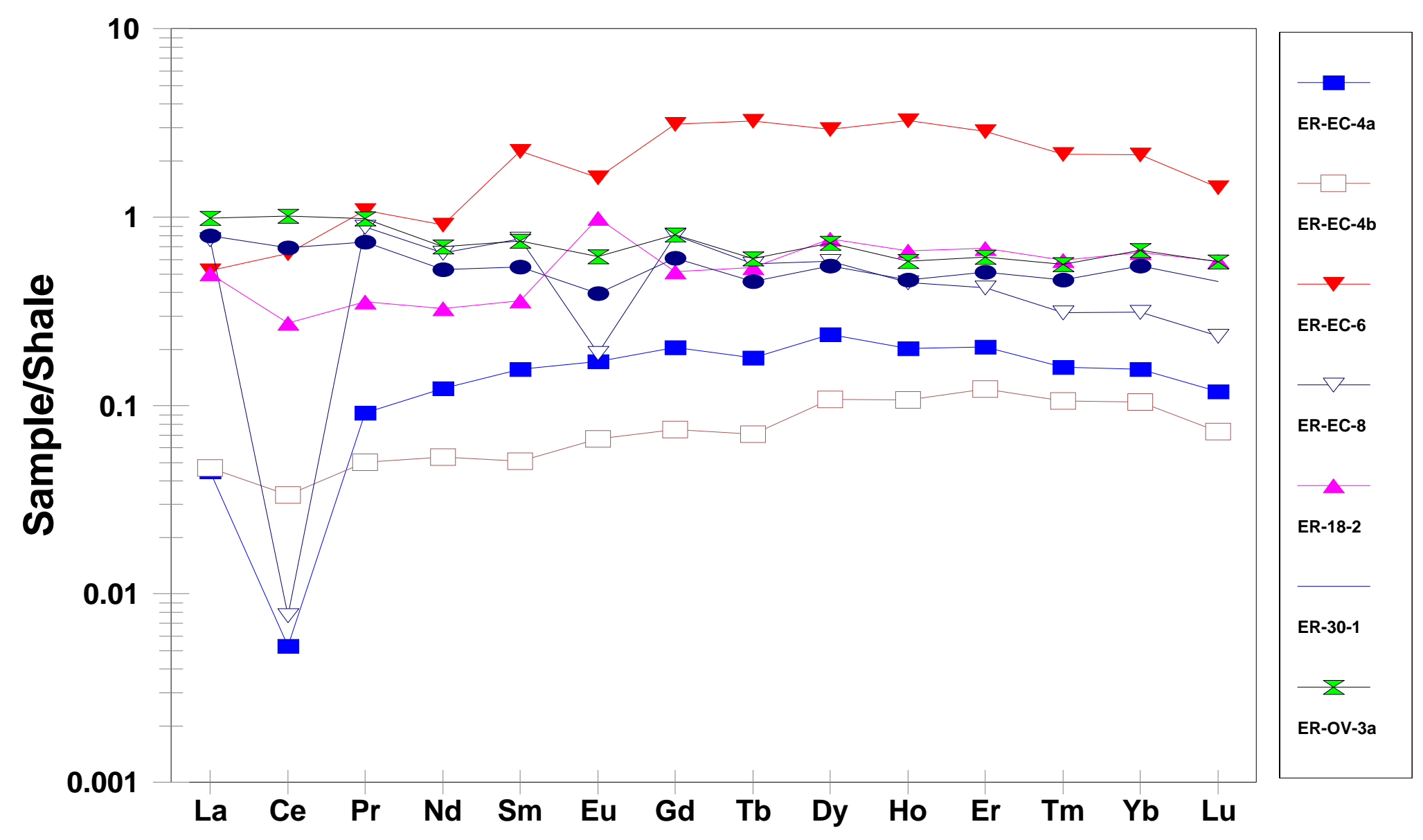




\section{Tables}




\begin{tabular}{|c|c|c|c|c|c|c|c|c|}
\hline \begin{tabular}{|l} 
Well and \\
Depth Interval
\end{tabular} & $\begin{array}{l}\text { TABLE 1. DESCRIPTI } \\
\text { Sample Description }\end{array}$ & $\begin{array}{l}\text { CORES AN } \\
\text { Hydrostratigraphic } \\
\text { Unit }\end{array}$ & $\begin{array}{c}\text { UTTING } \\
\text { Stratigraphy/ } \\
\text { Lithology }\end{array}$ & $\begin{array}{l}\text { ELECT } \\
\text { Alteration } \\
\end{array}$ & $\begin{array}{l}\text { FOR ANA } \\
\text { Fracture } \\
\text { Characteristics }\end{array}$ & $\begin{array}{l}\text { ISS } \\
\text { Fracture-lining } \\
\text { Phases }\end{array}$ & $\begin{array}{l}\text { Evidence for } \\
\text { Dissolution? }\end{array}$ & $\begin{array}{c}\text { Analyses } \\
\text { Conducted }\end{array}$ \\
\hline \multicolumn{9}{|c|}{ 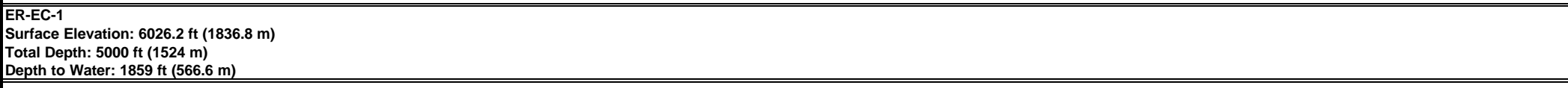 } \\
\hline$\frac{\text { Upper screene }}{2389^{\prime}}$ & $\frac{\text { terval - 2284-2867 ft (filter pack) }}{2.5 \times 2 \mathrm{~cm} \text { sidewall core }}$ & LFA & $\begin{array}{c}\text { Rhyolite } \\
\text { of } \\
\text { Benham }\end{array}$ & $\mathrm{DV} / \mathrm{S}$ & $\begin{array}{l}\text { open, multiple } \\
\text { intersecting } \\
\text { fractures }\end{array}$ & $\begin{array}{l}\text { chalcedony } \\
\text { illite } \\
\text { Fe-oxides }\end{array}$ & & SEM \\
\hline 2480-2490' & $1 \times 2 \mathrm{~cm}$ rock fragment from cuttings & LFA & $\begin{array}{l}\text { Rhyolite } \\
\text { of } \\
\text { Benham }\end{array}$ & $\mathrm{DV} / \mathrm{S}$ & $\begin{array}{l}\text { irregular, } \\
\text { rough } \\
\text { open fracture } \\
\text { surface }\end{array}$ & $\begin{array}{l}\text { quartz } \\
\text { k'spar } \\
\text { chalcedony } \\
\text { Fe-oxides } \\
\text { Mn-oxides }\end{array}$ & $\begin{array}{l}\text { yes } \\
\text { yes }\end{array}$ & SEM \\
\hline 2800-2810' & $1 \times 2 \mathrm{~cm}$ rock fragment from cuttings & WTA & $\begin{array}{l}\text { Pahute Mesa } \\
\text { lobe of Tiva } \\
\text { Canyon Tuff }\end{array}$ & DV & $\begin{array}{l}\text { irregular, } \\
\text { rough } \\
\text { open fracture } \\
\text { surface } \\
\end{array}$ & $\begin{array}{l}\text { chalcedony } \\
\text { illite } \\
\text { smectite } \\
\text { Mn-oxides } \\
\end{array}$ & & SEM \\
\hline$\frac{\text { Middle screene }}{3480-3490^{\prime}}$ & $\frac{\text { terval - 3318-3776 ft (filter pack) }}{\text { thin calcite veinlets in cuttings }}$ & WTA & $\begin{array}{l}\text { Prow Pass } \\
\text { Tuff }\end{array}$ & DV & $\begin{array}{l}\text { thin, filled } \\
\text { fractures } \\
\text { (up to } 1 \mathrm{~mm} \text { ) }\end{array}$ & $\begin{array}{l}\text { chalcedony } \\
\text { calcite }\end{array}$ & & $\delta^{13} \mathrm{C}, \delta^{18} \mathrm{O}$ \\
\hline$\frac{\text { Lower screene }}{4520-4580^{\prime}}$ & $\frac{\text { erval - } 4433-4840 \mathrm{ft} \text { (filter pack) }}{\text { calcite vein material; from cuttings }}$ & LFA & $\begin{array}{l}\text { Volcanics of } \\
\text { Quartz } \\
\text { Mountain } \\
\end{array}$ & QF & $\begin{array}{l}\text { filled fractures } \\
\text { (up to } 3 \mathrm{~mm} \text { ) }\end{array}$ & calcite & yes & $\delta^{13} \mathrm{C}, \delta^{18} \mathrm{O}$ \\
\hline $4530^{\prime}$ & $2.5 \times 2.5 \mathrm{~cm}$ intact length of sidewall core & LFA & $\begin{array}{l}\text { Volcanics of } \\
\text { Quartz } \\
\text { Mountain }\end{array}$ & QF & $\begin{array}{l}\text { largely } \\
\text { filled } \\
\text { fracture }\end{array}$ & $\begin{array}{l}\text { smectite } \\
\text { Fe-oxides }\end{array}$ & & SEM \\
\hline
\end{tabular}




\begin{tabular}{|c|c|c|c|c|c|c|c|c|}
\hline \begin{tabular}{|l} 
Well and \\
Depth Interval \\
ER-EC-4 \\
Surface Elevatio \\
Total Depth: 348 \\
Depth to Water: \\
\end{tabular} & $\begin{array}{l}\text { TABLE 1. DESCRIPTIC } \\
\text { Sample Description } \\
4759.8 \mathrm{ft}(1450.8 \mathrm{~m}) \\
\mathrm{t}(1063.1 \mathrm{~m}) \\
\mathrm{ft}(228.4 \mathrm{~m})\end{array}$ & $\begin{array}{c}\text { CORES AN } \\
\begin{array}{c}\text { Hydrostratigraphic } \\
\text { Unit }\end{array} \\
\end{array}$ & $\begin{array}{c}\text { CUTTINGS } \\
\begin{array}{c}\text { Stratigraphy/ } \\
\text { Lithology }\end{array} \\
\end{array}$ & $\begin{array}{r}\text { ELECT } \\
\text { Alteration } \\
\end{array}$ & $\begin{array}{c}\text { FOR ANA } \\
\text { Fracture } \\
\text { Characteristics }\end{array}$ & $\begin{array}{l}\text { YSIS } \\
\begin{array}{c}\text { Fracture-lining } \\
\text { Phases }\end{array} \\
\end{array}$ & $\begin{array}{l}\text { Evidence for } \\
\text { Dissolution? }\end{array}$ & $\begin{array}{c}\text { Analyses } \\
\text { Conducted }\end{array}$ \\
\hline \multicolumn{9}{|c|}{ Upper screened interval - 965-1240 ft (filter pack) } \\
\hline $960-970^{\prime}$ & calcite vein material; from cuttings & LFA & $\begin{array}{l}\text { Trachyte of } \\
\text { Ribbon Cliff }\end{array}$ & DV & $\begin{array}{l}\text { vein fillings and } \\
\text { vesicle fillings }\end{array}$ & $\begin{array}{c}\text { calcite } \\
\text { chalcedony } \\
\text { clinoptilolite }\end{array}$ & yes & $\delta^{13} \mathrm{C}, \delta^{18} \mathrm{O}$ \\
\hline 1070-1090' & $1 \mathrm{~cm}$ pieces from cuttings & LFA & $\begin{array}{l}\text { Trachyte of } \\
\text { Ribbon Cliff }\end{array}$ & DV/ZE & $\begin{array}{c}\text { probable } \\
\text { vesicle fillings }\end{array}$ & $\begin{array}{l}\text { clinoptilolite } \\
\text { mordenite } \\
\text { chalcedony }\end{array}$ & & SEM \\
\hline $1150-1160^{\prime}$ & calcite vein material; in cuttings & LFA & $\begin{array}{l}\text { Trachyte of } \\
\text { Ribbon Cliff }\end{array}$ & DVIZE & $\begin{array}{c}\text { probable } \\
\text { vesicle fillings }\end{array}$ & $\begin{array}{c}\text { clinoptilolite } \\
\text { levyne } \\
\text { chalcedony } \\
\text { clays } \\
\text { calcite } \\
\end{array}$ & & $\delta^{13} \mathrm{C}, \delta^{18} \mathrm{O}$, ICP-MS \\
\hline $1298^{\prime}$ & $2.5 \times 2.5 \mathrm{~cm}$ intact length of sidewall core & LFA & $\begin{array}{l}\text { Trachyte of } \\
\text { Ribbon Cliff }\end{array}$ & DV/ZE & $\begin{array}{c}\text { minimal } \\
\text { fracture coatings }\end{array}$ & $\begin{array}{c}\text { chalcedony } \\
\text { smectite/illite }\end{array}$ & & SEM \\
\hline \multicolumn{9}{|c|}{ Middle screened interval - 1874-2295 ft (filter pack) } \\
\hline 1910-1920' & $1 \mathrm{~cm}$ rock fragment; from cuttings & TCU & $\begin{array}{l}\text { Rhyolite of } \\
\text { Beatty Wash }\end{array}$ & ZE & uncertain & heulandite & & SEM \\
\hline 1920-1930' & thin calcite coatings on cuttings & LFA & $\begin{array}{l}\text { Trachyte of } \\
\text { East Cat Canyon }\end{array}$ & ZE & vesicle fillings & $\begin{array}{c}\text { chalcedony } \\
\text { calcite } \\
\text { Fe-oxides } \\
\text { clays } \\
\end{array}$ & & $\delta^{13} \mathrm{C}, \delta^{18} \mathrm{O}$ \\
\hline 2030-2040' & $1 \times 2 \mathrm{~cm}$ rock fragment from cuttings & WTA & $\begin{array}{c}\text { Mafic-poor } \\
\text { Ammonia Tanks }\end{array}$ & QF & $\begin{array}{c}\text { probable } \\
\text { vesicle fillings }\end{array}$ & $\begin{array}{c}\text { chalcedony } \\
\text { dolomite/calcite } \\
\text { Fe-oxides } \\
\text { K-spar }\end{array}$ & yes & SEM \\
\hline 2110-2120' & $1 \times 2 \mathrm{~cm}$ rock fragment from cuttings & WTA & $\begin{array}{c}\text { Mafic-poor } \\
\text { Ammonia Tanks }\end{array}$ & QF & $\begin{array}{l}\text { poorly preserved } \\
\text { fracture filling }\end{array}$ & $\begin{array}{l}\text { chalcedony } \\
\text { Mn-oxides } \\
\text { Fe-oxides }\end{array}$ & & SEM \\
\hline 2210-2220' & calcite vein fragment in cuttings & WTA & $\begin{array}{c}\text { Mafic-poor } \\
\text { Ammonia Tanks }\end{array}$ & QF & $\begin{array}{c}\text { fracture filling } \\
\text { devoid of matrix }\end{array}$ & calcite (2 generations) & & $\delta^{13} \mathrm{C}, \delta^{18} \mathrm{O}$, ICP-MS \\
\hline 2240-2250' & $1 \times 2 \mathrm{~cm}$ rock fragment from cuttings & WTA & $\begin{array}{c}\text { Mafic-poor } \\
\text { Ammonia Tanks }\end{array}$ & QF & $\begin{array}{c}\text { probable } \\
\text { vesicle fillings }\end{array}$ & $\begin{array}{c}\text { zeolites } \\
\text { chabazite (?) } \\
\text { phillipsite (?) }\end{array}$ & & SEM \\
\hline \multicolumn{9}{|c|}{ Lower screened interval - 3074-3468 ft (filter pack) } \\
\hline $3300^{\prime}$ & $2.5 \times 1.2 \mathrm{~cm}$ intact length of sidewall core & WTA & $\begin{array}{l}\text { Mafic-poor } \\
\text { Rainier Mesa }\end{array}$ & QF & $\begin{array}{l}\text { rough, irregular } \\
\text { fracture surface }\end{array}$ & $\begin{array}{c}\text { quartz } \\
\text { Fe-oxides }\end{array}$ & & SEM \\
\hline
\end{tabular}




\begin{tabular}{|c|c|c|c|c|c|c|c|c|}
\hline \begin{tabular}{|l|} 
Well and \\
Depth Interval \\
ER-EC-5 \\
Surface Elevatio \\
Total Depth: 250 \\
Depth to Water:
\end{tabular} & $\begin{array}{l}\text { TABLE 1. DESCRIPTION } \\
\text { Sample Description } \\
\begin{array}{l}5077.2 \mathrm{ft}(1547.9 \mathrm{~m}) \\
\mathrm{t}(762.2 \mathrm{~m}) \\
18 \mathrm{ft}(310.3 \mathrm{~m})\end{array}\end{array}$ & $\begin{array}{c}\text { CORES AN } \\
\text { Hydrostratigraphic } \\
\text { Unit }\end{array}$ & $\begin{array}{c}\text { CUTTINGS } \\
\begin{array}{c}\text { Stratigraphy } / \\
\text { Lithology }\end{array} \\
\end{array}$ & $\begin{array}{l}\text { ELECT } \\
\text { Alteration } \\
\end{array}$ & $\begin{array}{c}\text { D FOR ANAL } \\
\begin{array}{c}\text { Fracture } \\
\text { Characteristics }\end{array} \\
\end{array}$ & $\begin{array}{l}\text { SIS } \\
\text { Fracture-lining } \\
\text { Phases } \\
\end{array}$ & $\begin{array}{l}\text { Evidence for } \\
\text { Dissolution? }\end{array}$ & $\begin{array}{c}\text { Analyses } \\
\text { Conducted } \\
\end{array}$ \\
\hline \multicolumn{9}{|c|}{ Upper screened interval - 1187-1443 ft (filter pack) } \\
\hline $1190-1210^{\prime}$ & sparse calcite veinlets from cuttings & WTA & $\begin{array}{l}\text { Mafic-rich } \\
\text { Ammonia Tanks }\end{array}$ & QF & $\begin{array}{l}\text { irregular filled } \\
\text { fractures }\end{array}$ & $\begin{array}{c}\text { calcite } \\
\text { Mn-oxides }\end{array}$ & yes & $\delta^{13} \mathrm{C}, \delta^{18} \mathrm{O}$ \\
\hline $1200^{\prime}$ & $3 \times 2 \mathrm{~cm}$ split sidewall core & WTA & $\begin{array}{c}\text { Mafic-rich } \\
\text { Ammonia Tanks }\end{array}$ & QF & $\begin{array}{l}\text { spatrse coating on } \\
\text { irregular surface }\end{array}$ & Mn-oxide & & SEM \\
\hline $1440^{\prime}$ & $2.5 \times 1.2 \mathrm{~cm}$ split sidewall core & WTA & $\begin{array}{c}\text { Mafic-ich } \\
\text { Ammonia Tanks }\end{array}$ & QF & $\begin{array}{l}\text { irregular surface with } \\
\text { sparse fracture }\end{array}$ & $\begin{array}{c}\text { barite } \\
\text { scheelite } \\
\text { cuprotungstite } \\
\end{array}$ & yes & SEM \\
\hline \multicolumn{9}{|c|}{ Middle screened interval - 1855-2146 ft (filter pack) } \\
\hline $1900-1910^{\prime}$ & sparse calcite fracture coatings from cuttings & WTA & $\begin{array}{l}\text { Mafic-rich } \\
\text { Ammonia Tanks }\end{array}$ & QF & $\begin{array}{l}\text { rare thin fracture } \\
\text { coatings }\end{array}$ & $\begin{array}{c}\text { calcite } \\
\text { Fe-oxides }\end{array}$ & & $\delta^{13} \mathrm{C}, \delta^{18} \mathrm{O}$ \\
\hline $2105^{\prime}$ & $2.5 \times 1.2 \mathrm{~cm}$ split sidewall core & WTA & $\begin{array}{c}\text { Mafic-rich } \\
\text { Ammonia Tanks }\end{array}$ & QF & $\begin{array}{l}\text { fine grained, granular } \\
\text { surface }\end{array}$ & $\begin{array}{l}\text { illite/smectite } \\
\text { chalcedony } \\
\text { Fe-oxides }\end{array}$ & & SEM \\
\hline $21355^{\prime}$ & $2.5 \times 1 \mathrm{~cm}$ split sidewall core & WTA & $\begin{array}{c}\text { Mafic-rich } \\
\text { Ammonia Tanks }\end{array}$ & QF & $\begin{array}{l}\text { poorly coated } \\
\text { irregular fracture }\end{array}$ & $\begin{array}{c}\text { Fe-oxides } \\
\text { calcite } \\
\text { apatite } \\
\end{array}$ & $\begin{array}{l}\text { yes } \\
\text { yes }\end{array}$ & SEM \\
\hline \begin{tabular}{|l} 
Lower screened \\
$2380-2390^{\prime}$
\end{tabular} & $\begin{array}{l}\text { terval - 2223-2480 } \mathrm{ft} \text { (filter pack) } \\
\text { sparse calcite fracture coatings on cuttings }\end{array}$ & WTA & $\begin{array}{c}\text { Maafic-poor } \\
\text { Ammonia Tanks }\end{array}$ & QF & $\begin{array}{l}\text { sparse, thin fracture } \\
\text { coatings }\end{array}$ & $\begin{array}{c}\text { calcite } \\
\text { Fe-oxides } \\
\text { Mn-oxides }\end{array}$ & yes & $\delta^{13} \mathrm{C}, \delta^{18} \mathrm{O}$ \\
\hline \multicolumn{9}{|c|}{ 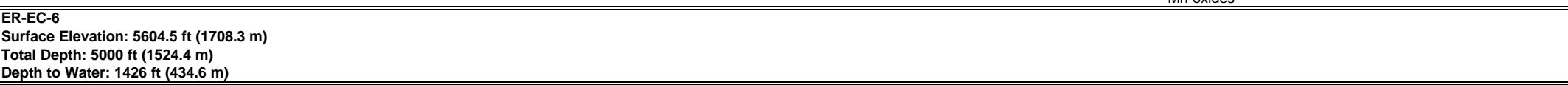 } \\
\hline \multicolumn{9}{|c|}{ Second screened interval - 2170-2510 ft (filter pack) } \\
\hline $2230-2250^{\prime}$ & calcite veinlets/coatings from cuttings & TCU & $\begin{array}{c}\text { Rhyolite of } \\
\text { Scrugham Peak }\end{array}$ & QF & $\begin{array}{l}\text { very sparse } \\
\text { vein fillings }\end{array}$ & $\begin{array}{c}\text { calcite } \\
\text { Mn-oxide }\end{array}$ & yes & $\delta^{13} \mathrm{C}, \delta^{18} \mathrm{O}$ \\
\hline $2415^{\prime}$ & $2.5 \times 0.6 \mathrm{~cm}$ intact sidewall core & WTA & $\begin{array}{l}\text { Pahute Mesa lobe of } \\
\text { Topopah Spring Tuff }\end{array}$ & QF & $\begin{array}{l}\text { moderate fracture } \\
\text { coating development } \\
\text { on irregular surface }\end{array}$ & $\begin{array}{l}\text { calcite } \\
\text { chalcedony } \\
\text { smectite } \\
\text { illite } \\
\text { Fe-oxides } \\
\text { Mn-oxides } \\
\end{array}$ & yes & SEM \\
\hline $2445^{\prime}$ & $3.8 \times 2.5 \mathrm{~cm}$ split sidewall core & WTA & $\begin{array}{l}\text { Pahute Mesa lobe of } \\
\text { Topopah Spring Tuff }\end{array}$ & QF & $\begin{array}{l}\text { minimal fracture } \\
\text { coating development } \\
\text { on irregular surface }\end{array}$ & $\begin{array}{c}\text { quartz } \\
\text { smectite } \\
\text { Fe-oxides } \\
\text { Mn-oxides } \\
\end{array}$ & & SEM \\
\hline \multicolumn{9}{|c|}{ Third screened interval - 3423-3820 ft (filter pack) } \\
\hline $3420-3440^{\prime}$ & calcite veins/coatings from cuttings & WTA & $\begin{array}{l}\text { Pahute Mesa lobe of } \\
\text { Topopah Spring Tuff }\end{array}$ & QF & $\begin{array}{l}\text { veinlets and/or } \\
\text { filled fractures }\end{array}$ & calcite & & $\delta^{13} \mathrm{C}, \delta^{18} \mathrm{O}$, ICP-MS \\
\hline $3445^{\prime}$ & $2.5 \times 1 \mathrm{~cm}$ split sidewall core & WTA & $\begin{array}{l}\text { Pahute Mesa lobe of } \\
\text { Topopah Spring Tuff }\end{array}$ & QF & $\begin{array}{l}\text { moderate fracture } \\
\text { coating development } \\
\text { on irregular surface }\end{array}$ & $\begin{array}{l}\text { smectite or chlorite } \\
\text { chalcedony } \\
\text { calcite }\end{array}$ & & SEM \\
\hline
\end{tabular}




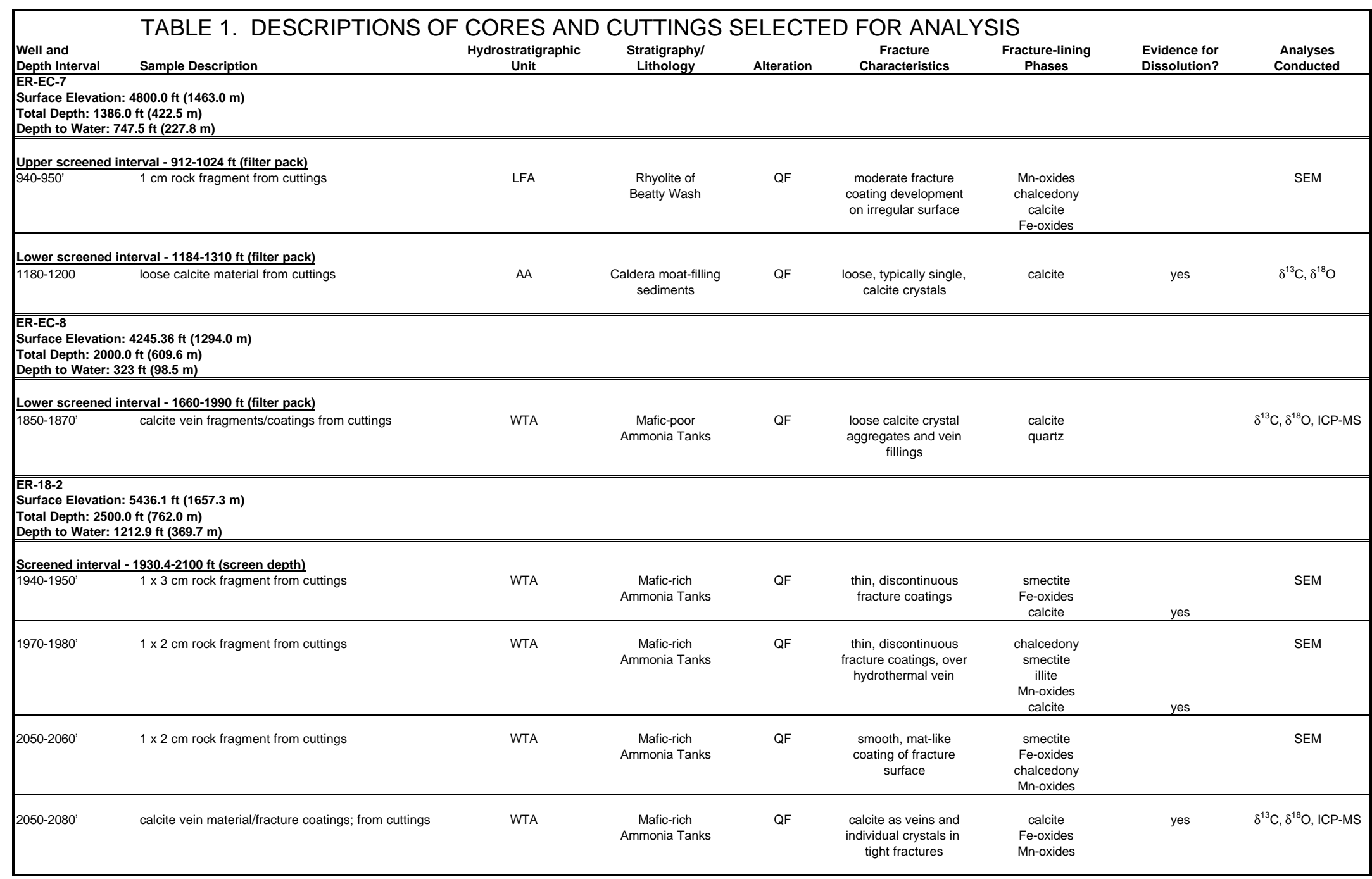




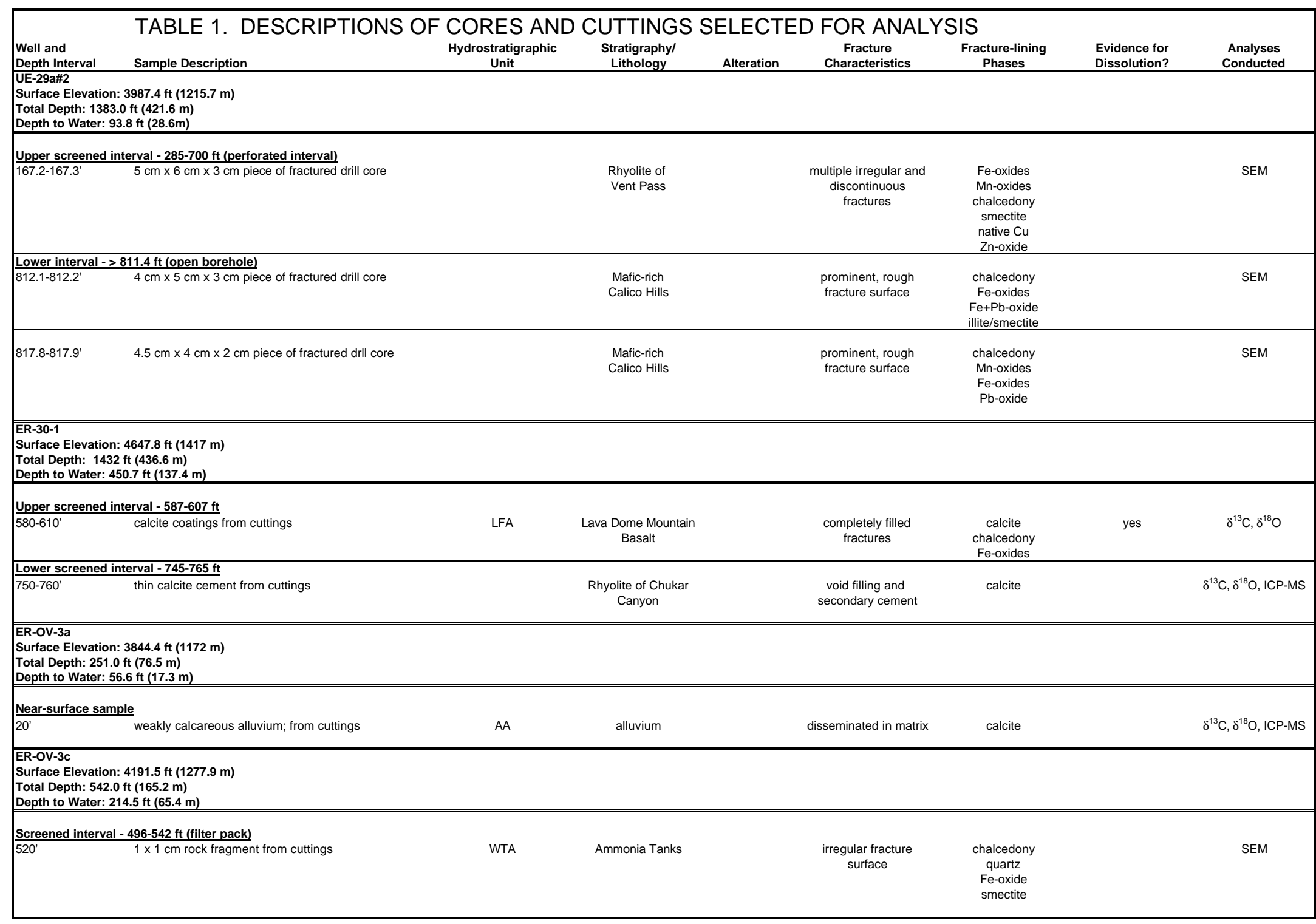




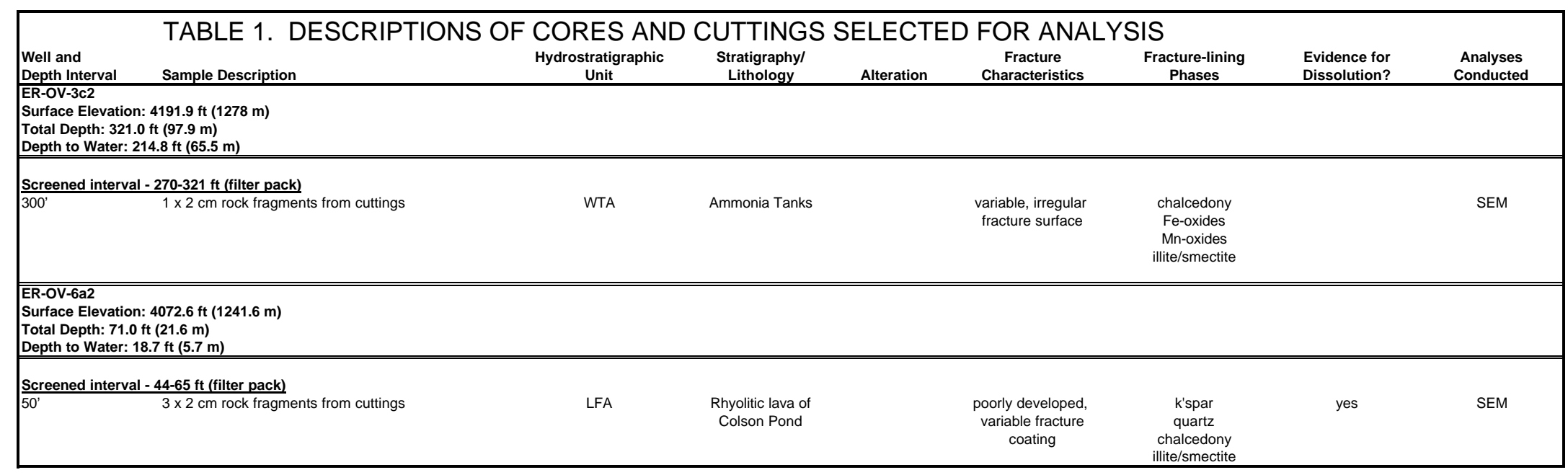

EXPLANATION FOR TABLE 1 PARAMETERS

\begin{tabular}{ll} 
Hydrostratigraphic Units \\
\hline LA & Lava flow aquifer \\
WTA & Welded tuff aquife \\
TCU & Tuff confining unit
\end{tabular}

$\begin{array}{ll}\text { WTA } & \text { Welded tuff aquifer } \\ \text { TCU } & \text { Tuff confining unit }\end{array}$

AA Alluvial aquifer

Alteration Styles

$\begin{array}{ll}\text { DV } & \text { Devitrification } \\ S & \text { Silification }\end{array}$

$\begin{array}{ll}\mathrm{S} & \text { Silicification } \\ \mathrm{QF} & \text { Quartzofeldspathic alteration }\end{array}$

Zeolitic 


\begin{tabular}{|c|c|c|c|c|c|c|c|c|c|c|c|c|c|c|c|}
\hline \multirow{3}{*}{$\begin{array}{l}\text { SAMPLE ID } \\
\text { WELL/NTERVAL } \\
\text { ER-EC-1/2389 }\end{array}$} & \multirow{3}{*}{\begin{tabular}{|c|} 
SURFACE \\
AREA (mm^ 2$)$ \\
$>500$
\end{tabular}} & \multirow{3}{*}{$\begin{array}{l}\text { SURFACE } \\
\begin{array}{|c|}\text { PERCENT } \\
\text { PEVERAGE } \\
30-40\end{array}\end{array}$} & \multirow{3}{*}{\begin{tabular}{|c|} 
ROPERTIE \\
LOCAL \\
RELIEF \\
$>0.1$ \\
\\
\end{tabular}} & \multirow{3}{*}{\begin{tabular}{|l|}
\multicolumn{1}{|c|}{ TEXTURE } \\
irregular, smooth \\
blocky to granular \\
surface with \\
intersecting \\
fractures
\end{tabular}} & \multicolumn{5}{|c|}{ NATURE OF SURFACE PORES } & \multicolumn{6}{|c|}{ FRACTURE COATING MINERALOGY } \\
\hline & & & & & ANGULARITY & ELONGATION & \begin{tabular}{|l} 
LENGTH \\
MAX (mm)
\end{tabular} & \begin{tabular}{|c|} 
WIDTH \\
$\operatorname{MAX}(\mathrm{mm})$ \\
\end{tabular} & $\begin{array}{c}\text { DEPTH } \\
(\mathrm{mm})\end{array}$ & PHASE & MORPHOLOGY & $\begin{array}{l}\text { LENGTH } \\
\text { MAX (mm) }\end{array}$ & \begin{tabular}{|c|} 
WIDTH \\
$\operatorname{MAX}(\mathrm{mm})$
\end{tabular} & $\begin{array}{l}\text { \% OF } \\
\text { TOTAL }\end{array}$ & COMMENTS \\
\hline & & & & & \begin{tabular}{|l} 
angular \\
\end{tabular} & variable & 0.015 & 0.015 & 0.015 & $\begin{array}{c}\mathrm{FeOX} \\
\mathrm{CY}\end{array}$ & $\begin{array}{l}\begin{array}{l}\text { elongate aggregates and mat-like } \\
\text { accumulations }\end{array} \\
\text { irregular aggregates and surface } \\
\text { disseminations } \\
\text { mat-like accumulations with } \\
\text { chalcedony }\end{array}$ & $\begin{array}{c}0.1 \\
<0.002\end{array}$ & $\begin{array}{c}0.1 \\
<0.002\end{array}$ & $\begin{array}{l}3-5 \\
8-10\end{array}$ & $\begin{array}{l}\text { typically mixed with ilitite as a mat- } \\
\text { like aggregate }\end{array}$ \\
\hline $\begin{array}{l}\mid \mathrm{ER}-\mathrm{EC}-1 / 2480- \\
2490\end{array}$ & 200 & 90 & $>0.1$ & $\begin{array}{l}\text { irregular, rough } \\
\text { blocky to granular } \\
\text { surface }\end{array}$ & angular & $\begin{array}{l}\text { elongate, } \\
\text { variable }\end{array}$ & 0.1 & 0.1 & 0.1 & $\begin{array}{c}\text { KF } \\
\text { QC } \\
\text { FeOX } \\
\text { CY } \\
\text { MnOX }\end{array}$ & $\begin{array}{l}\text { large blocky to tabular crystals with } \\
\text { surfaces now dominated by ragged, } \\
\text { silica-rich surface } \\
\text { typically blocky and irregular } \\
\text { crystals in accumulations } \\
\text { as spheres and botryoidal } \\
\text { accumulations } \\
\text { small irregular aggregates } \\
\text { as acicular prisms }\end{array}$ & $\begin{array}{l}0.3 \\
0.02 \\
0.005 \\
\\
0.002 \\
0.015\end{array}$ & $\begin{array}{l}0.05 \\
0.003 \\
0.005 \\
\\
0.002 \\
0.001\end{array}$ & $\begin{array}{c}88 \\
1 \\
0.5 \\
0.5 \\
\operatorname{tr} \\
0.5\end{array}$ & $\begin{array}{l}\text { residual, solution pitted surface } \\
\text { localized spheres and } \\
\text { accumulations into botryoidal } \\
\text { masses } \\
\text { overgrowths on eroded feldspar } \\
\text { and in granular areas beween } \\
\text { larger crystals }\end{array}$ \\
\hline $\begin{array}{l}\text { ER-EC-1/2800- } \\
2810\end{array}$ & 200 & $40-50$ & 0.05 & $\begin{array}{l}\text { smooth matted, to } \\
\text { granular, to blocky } \\
\text { (uncoated) surface }\end{array}$ & smooth & irregular & 0.01 & 0.01 & 0.01 & $\begin{array}{c}\mathrm{QC} \\
\mathrm{CY} \\
\mathrm{CY} \\
\mathrm{MnOX}\end{array}$ & \begin{tabular}{|l|} 
as fine grained component in \\
surface coating mat \\
as fine grained component in \\
surface coating mat \\
as fine grained component in \\
surface coating mat \\
as fine grained to massive, \\
polycrystalline mass on surface \\
\end{tabular} & $\begin{array}{l}0.004 \\
<0.002 \\
<0.002 \\
<0.002\end{array}$ & $\begin{array}{l}0.004 \\
<0.002 \\
<0.002 \\
<0.002\end{array}$ & $\begin{array}{c}20-25 \\
10-15 \\
5-10 \\
<1\end{array}$ & |illite \\
\hline ER-EC-1/4530 & $>500$ & 100 & $>0.1$ & $\begin{array}{l}\text { fractured filled with } \\
\text { clay and minor } \\
\text { oxides }\end{array}$ & smooth & variable & 0.05 & 0.05 & 0.05 & $\begin{array}{l}\mathrm{CY} \\
\mathrm{FeOX}\end{array}$ & $\begin{array}{l}\text { mat-like accumulation, locally } \\
\text { exhibiting web-like intergrowths and } \\
\text { terminations } \\
\text { spheres and denditic accumulations } \\
\text { of spheres }\end{array}$ & $\begin{array}{c}<0.002 \\
0.2\end{array}$ & $\begin{array}{c}<0.002 \\
0.2\end{array}$ & $1-2$ & smectite \\
\hline ER-EC-4/1298 & $>500$ & 20 & 0.01 & $\begin{array}{l}\text { smooth to blocky } \\
\text { with minor granular } \\
\text { coating }\end{array}$ & angular & elongate & 0.05 & 0.03 & 0.01 & $\begin{array}{l}\mathrm{QC} \\
\mathrm{CY} \\
\mathrm{KF}\end{array}$ & $\begin{array}{l}\text { irreguar grains and sparse local } \\
\text { accumulations as 'dusting' on } \\
\text { fracture surface } \\
\text { irreguar sparse local accumulations } \\
\text { as 'dusting' on fracture surface } \\
\text { irregular grains as 'dusting on } \\
\text { fracture syrface }\end{array}$ & $\begin{array}{r}0.01 \\
<0.002 \\
0.01\end{array}$ & $\begin{array}{r}0.005 \\
<0.002 \\
0.01\end{array}$ & $\begin{array}{l}5 \\
5\end{array}$ & mixed smectite/illite \\
\hline \begin{tabular}{|l} 
ER-EC-4/1910- \\
1920
\end{tabular} & 100 & 100 & $>0.1$ & blocky & angular & variable & 0.1 & 0.1 & 0.01 & ZE & intergrown euhedral crystals & 0.8 & 0.5 & 100 & heulandite \\
\hline
\end{tabular}




\begin{tabular}{|c|c|c|c|c|c|c|c|c|c|c|c|c|c|c|c|}
\hline \multirow[b]{2}{*}{$\begin{array}{l}\text { SAMPLE ID } \\
\text { WELLINTERVAL }\end{array}$} & \multicolumn{4}{|c|}{ SURFACE PROPERTIES } & \multicolumn{5}{|c|}{ NATURE OF SURFACE PORES } & \multicolumn{6}{|c|}{ FRACTURE COATING MINERALOGY } \\
\hline & $\begin{array}{l}\text { SURFACE } \\
\text { AREA }\left(\mathrm{mm}^{\wedge} 2\right)\end{array}$ & \begin{tabular}{|l} 
PERCENT \\
COVERAGE
\end{tabular} & $\begin{array}{l}\text { LOCAL } \\
\text { RELIEF }\end{array}$ & TEXTURE & ANGULARITY & ELONGATION & \begin{tabular}{|l|} 
LENGTH \\
MAX $(\mathrm{mm})$
\end{tabular} & \begin{tabular}{|c|} 
WIDTH \\
MAX (mm) \\
\end{tabular} & $\begin{array}{c}\text { DEPTH } \\
(\mathrm{mm})\end{array}$ & PHASE & MORPHOLOGY & $\begin{array}{l}\text { LENGTH } \\
\text { MAX }(\mathrm{mm})\end{array}$ & \begin{tabular}{|c|} 
WIDTH \\
$\operatorname{MAX}(\mathrm{mm})$
\end{tabular} & $\begin{array}{l}\text { \% OF } \\
\text { TOTAL }\end{array}$ & COMMENTS \\
\hline $\begin{array}{l}\text { ER-EC-4/2030- } \\
2040\end{array}$ & 200 & 100 & $>0.1$ & \begin{tabular}{|l|}
$\begin{array}{l}\text { rough vuggy surface } \\
\text { with well developed } \\
\text { coatings }\end{array}$
\end{tabular} & $\begin{array}{l}\text { variable, more } \\
\text { typically } \\
\text { smooth }\end{array}$ & variable & $>1.0$ & $>1.0$ & $>1.0$ & $\begin{array}{l}\text { FeOX } \\
\text { ZE } \\
\text { QC }\end{array}$ & $\begin{array}{l}\text { fine grained polycrystalline } \\
\text { aggreagetes lining vesicles. Multiple } \\
\text { generations apparent }\end{array}$ & $\begin{array}{l} \\
0.1 \\
0.15 \\
0.01\end{array}$ & $\begin{array}{l}0.002 \\
0.05 \\
0.01\end{array}$ & $\begin{array}{l} \\
20-25 \\
15-20 \\
<5\end{array}$ & $\begin{array}{l}\text { surface exhibits pitting, } \\
\text { suggesting dissolution }\end{array}$ \\
\hline 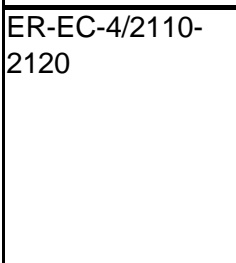 & 200 & 100 & 0.05 & \begin{tabular}{|l|}
$\begin{array}{l}\text { moderately rough } \\
\text { granular to blocky } \\
\text { smooth and mattled }\end{array}$ \\
\end{tabular} & $\begin{array}{l}\text { variable, } \\
\text { typically } \\
\text { smooth with } \\
\text { local vugs }\end{array}$ & rounded vugs & 0.25 & 0.25 & 0.15 & $\begin{array}{l}\text { MnOX } \\
\text { FeOX }\end{array}$ & \begin{tabular}{|l|} 
fine grained polycrystalline to \\
massive fracture filling \\
massive aggregates \\
aggregates of elongate crystals
\end{tabular} & $\begin{array}{l}0.15 \\
0.01\end{array}$ & $\begin{array}{c}0.03 \\
<0.002 \\
\end{array}$ & $\begin{array}{c}20 \\
5\end{array}$ & intergrown with Mn-OX and QC \\
\hline \begin{tabular}{|l} 
ER-EC-4/2240- \\
2250
\end{tabular} & 200 & 100 & $>0.1$ & $\begin{array}{l}\text { rough blocky } \\
\text { surface }\end{array}$ & angular & 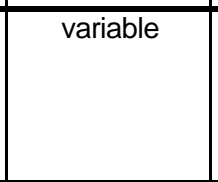 & 0.4 & 0.4 & 0.4 & $\begin{array}{l}\mathrm{ZE} \\
\mathrm{ZE}\end{array}$ & $\begin{array}{l}\text { euhedral blocky crystals } \\
\text { acicular to fine blocky prisms, } \\
\text { aggregates }\end{array}$ & $\begin{array}{l}0.7 \\
0.05\end{array}$ & $\begin{array}{l}0.5 \\
0.01\end{array}$ & $\begin{array}{c}95-98 \\
1-2\end{array}$ & $\begin{array}{l}\text { possible chabazite, based on } \\
\text { morphology, EDS } \\
\text { possible philipsite, based on } \\
\text { morphology, EDS }\end{array}$ \\
\hline ER-EC-4/3300 & 300 & 100 & $>0.5$ & \begin{tabular}{|l|} 
irregular surface \\
dominated by \\
accumulation of \\
subsherical \\
aggregates of quartz \\
crystals
\end{tabular} & $\begin{array}{l}\text { variable, } \\
\text { typically } \\
\text { angular }\end{array}$ & 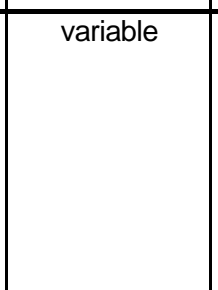 & 0.1 & 0.1 & 0.1 & FeOX & $\begin{array}{l}\text { accumulations of sub-spherical } \\
\text { aggregates of euhedral to subhedral } \\
\text { quartz crystals } \\
\text { sparse dendritic clusters }\end{array}$ & 0.025 & 0.005 & $95-97$ & $\begin{array}{l}\begin{array}{l}\text { subspherical accumulations of } \\
\text { subhedral quartz prisms }\end{array} \\
\text { dendritic clusters }\end{array}$ \\
\hline ER-EC-5/1200 & (600 & $2-3$ & 0.05 & $\begin{array}{l}\begin{array}{l}\text { smooth and blocky } \\
\text { to granular }\end{array} \\
\end{array}$ & "angular & iirregular & $\overline{0.05}$ & 0.05 & $>0.05$ & MnOX & intergrown fibrous to acicular & 0.005 & "<0.002 & "60 & interlayered with clay minerals \\
\hline & & & & & & & & & & $\mathrm{CY}$ & intergrown web-like crystals & 0.005 & 0.005 & 40 & intergrown with $\mathrm{Mn}-\mathrm{OX}$ \\
\hline ER-EC-5/1440 & 300 & $2-3$ & 0.5 & $\begin{array}{l}\text { rough granular with } \\
\text { blocky off sets }\end{array}$ & angular & 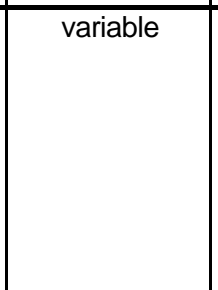 & 0.01 & 0.01 & 0.01 & $\begin{array}{l}\text { OT } \\
\text { OT }\end{array}$ & $\begin{array}{l}\text { irregular (erroded?) masses } \\
\text { irregular, massive accumulation } \\
\text { with abundant dessication cracks } \\
\text { dispersed anhedral grains }\end{array}$ & $\begin{array}{c}0.03 \\
0.5 \\
0.005\end{array}$ & $\begin{array}{l}0.03 \\
0.2 \\
0.005\end{array}$ & $\begin{array}{l}<1 \\
<1 \\
1-2\end{array}$ & $\begin{array}{l}\text { scheelite } \\
\text { cuprotungstite }\end{array}$ \\
\hline ER-EC-5/2105 & 300 & 100 & 0.1 & \begin{tabular}{|l} 
typically smooth \\
granular, locally \\
rough granular
\end{tabular} & smooth & ypically rounded & $<0.01$ & $<0.01$ & 0.01 & $\begin{array}{l}\mathrm{QC} \\
\mathrm{CY}\end{array}$ & $\begin{array}{l}\text { irregular to blocky crystals } \\
\text { irregular aggregates }\end{array}$ & 0.01 & $\begin{array}{l}0.004 \\
0.004\end{array}$ & $\begin{array}{l}30-35 \\
50-55\end{array}$ & \begin{tabular}{|l|} 
intermixed with other phases \\
probable illite and smectite \\
intermixed with other phases
\end{tabular} \\
\hline ER-EC-5/2135 & 250 & 10 & 0.01 & $\begin{array}{l}\text { typically smotth } \\
\text { granular surface }\end{array}$ & $\begin{array}{l}\text { typically } \\
\text { smooth }\end{array}$ & variable & $<0.01$ & $<0.01$ & 0.01 & $\begin{array}{c}\mathrm{FeOX} \\
\mathrm{FeOX} \\
\mathrm{CY} \\
\mathrm{QC} \\
\mathrm{CC}\end{array}$ & \begin{tabular}{|l} 
|irregular grains \\
eroded relicts \\
web-like accumulations \\
irregular grains \\
irregular grains in rock matrix
\end{tabular} & $\begin{array}{c}0.01 \\
0.2 \\
\\
0.002 \\
0.02 \\
0.1\end{array}$ & $\begin{array}{c}0.005 \\
0.2 \\
\\
0.002 \\
0.005 \\
0.04\end{array}$ & $\begin{array}{c}15-20 \\
5 \\
3 \\
2 \\
<1\end{array}$ & \begin{tabular}{|l|} 
intermixed with other phases \\
after primary phase (pyrite?)
\end{tabular} \\
\hline
\end{tabular}




\begin{tabular}{|c|c|c|c|c|c|c|c|c|c|c|c|c|c|c|c|}
\hline \multirow{2}{*}{$\begin{array}{l}\text { SAMPLE ID } \\
\text { WELL/NTERVAL }\end{array}$} & \multicolumn{4}{|c|}{\begin{tabular}{l|l} 
SURFACE PROPERTIES \\
SUIREACE
\end{tabular}} & \multicolumn{5}{|c|}{ NATURE OF SURFACE PORES } & \multicolumn{6}{|c|}{ FRACTURE COATING MINERALOGY } \\
\hline & $\begin{array}{c}\text { SURFACE } \\
\text { AREA }\left(\mathrm{mm}^{\wedge} 2\right)\end{array}$ & \begin{tabular}{|c|} 
PERCENT \\
COVERAGE \\
\end{tabular} & $\begin{array}{l}\text { LOCAL } \\
\text { RELIEF }\end{array}$ & TEXTURE & ANGULARITY & ELONGATION & \begin{tabular}{|c|} 
LENGTH \\
MAX $(\mathrm{mm})$
\end{tabular} & \begin{tabular}{|c|} 
WIDTH \\
$\operatorname{MAX}(\mathrm{mm})$
\end{tabular} & $\begin{array}{c}\text { DEPTH } \\
(\mathrm{mm})\end{array}$ & PHASE & MORPHOLOGY & $\begin{array}{l}\text { LENGTH } \\
\text { MAX }(\mathrm{mm})\end{array}$ & \begin{tabular}{|c|} 
WIDTH \\
$\operatorname{MAX}(\mathrm{mm})$
\end{tabular} & $\begin{array}{l}\text { \% OF } \\
\text { TOTAL }\end{array}$ & COMMENTS \\
\hline ER-EC-6/2415 & 150 & 100 & 0.01 & $\begin{array}{l}\text { smooth, matted to } \\
\text { granular }\end{array}$ & variable & variable & 0.01 & 0.01 & 0.01 & $\begin{array}{c}\mathrm{CC} \\
\mathrm{QC} \\
\mathrm{CY} \\
\mathrm{FeOX}\end{array}$ & $\begin{array}{l}\text { irregular grains and polycrystalline } \\
\text { masses in rock matrix } \\
\text { irregular grains } \\
\text { irregular grains } \\
\text { individual rounded grains and } \\
\text { botryoidal masses }\end{array}$ & $\begin{array}{l}0.5 \\
\\
0.002 \\
0.01 \\
0.05\end{array}$ & \begin{tabular}{|c|}
0.5 \\
\\
0.002 \\
0.005 \\
0.002 \\
\end{tabular} & 55 & $\begin{array}{l}\text { exhibits solution features } \\
\text { mixture of predominantly illite with } \\
\text { lesser chalcedony and smectite }\end{array}$ \\
\hline ER-EC-6/2445 & 950 & 40 & 0.01 & $\begin{array}{l}\text { moderately rough } \\
\text { granular }\end{array}$ & 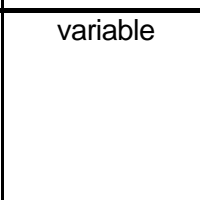 & variable & $<0.01$ & $<0.01$ & 0.01 & $\begin{array}{c}\text { QZ } \\
\text { FeOX } \\
\text { CY }\end{array}$ & \begin{tabular}{|l|} 
euhedral to subhedral terminated \\
crystals \\
individual rounded grains and \\
botryoidal masses \\
irregular grains
\end{tabular} & $\begin{array}{l}0.05 \\
0.05 \\
0.002\end{array}$ & $\begin{array}{l}0.015 \\
0.002 \\
0.002\end{array}$ & $\begin{array}{l}15 \\
15 \\
10\end{array}$ & $\begin{array}{l}\text { exhibits solution features } \\
\text { occurs with Fe-oxides }\end{array}$ \\
\hline ER-EC-6/3445 & 250 & 100 & $<0.01$ & $\begin{array}{l}\text { smooth to rough } \\
\text { granular }\end{array}$ & $\overline{\text { variable }}$ & variable & 0.01 & 0.01 & 0.01 & $\begin{array}{l}\mathrm{CY} \\
\mathrm{QC} \\
\mathrm{OT}\end{array}$ & $\begin{array}{l}\text { ragged plates and platy aggregates } \\
\text { irregular grains } \\
\text { irregular grains }\end{array}$ & $\begin{array}{l}0.015 \\
0.002 \\
0.075\end{array}$ & $\begin{array}{l}0.015 \\
0.002 \\
0.025\end{array}$ & $\begin{array}{c}60-65 \\
30-35 \\
2-3\end{array}$ & $\begin{array}{l}\text { chlorite or Fe-rich smectite? } \\
\text { REE-bearing calcite (?) }\end{array}$ \\
\hline ER-EC-7/940-950 & 100 & 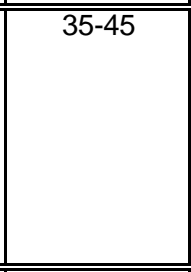 & 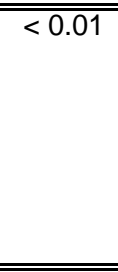 & $\begin{array}{l}\text { moderately rough } \\
\text { granular }\end{array}$ & 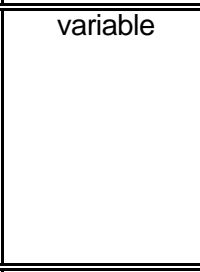 & $\begin{array}{l}\text { typically } \\
\text { angular }\end{array}$ & 0.025 & 0.025 & 0.025 & $\begin{array}{c}\mathrm{QZ} \\
\mathrm{MnOX} \\
\mathrm{QC} \\
\mathrm{CC} \\
\mathrm{FeOX} \\
\end{array}$ & $\begin{array}{l}\text { euhedral to subhedral terminated } \\
\text { crystals } \\
\text { variable, fibrous, mat-like, to } \\
\text { spheroidal } \\
\text { irrgular to blocky } \\
\text { irregular, solution etched } \\
\text { dendritic to botryoidal } \\
\end{array}$ & $\begin{array}{c}0.1 \\
0.3 \\
0.05 \\
0.005 \\
0.05 \\
\end{array}$ & $\begin{array}{r}0.025 \\
0.3 \\
0.05 \\
0.005 \\
<0.001 \\
\end{array}$ & $\begin{array}{c}10-15 \\
25-30 \\
2 \\
\operatorname{tr} \\
\operatorname{tr} \\
\end{array}$ & $\begin{array}{l}\text { exhibits solution features } \\
\text { Ba-bearing }\end{array}$ \\
\hline $\begin{array}{l}\text { ER-18-2/1940- } \\
1950\end{array}$ & 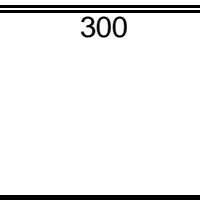 & "50-60 & 0.01 & $\begin{array}{l}\text { granular to smooth } \\
\text { matted, local blocky } \\
\text { offsets }\end{array}$ & smooth & 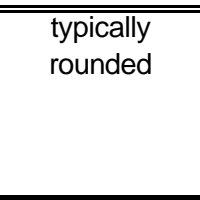 & "<0.01 & $\begin{array}{ll}<0.01 \\
\end{array}$ & "0.01 & $\begin{array}{l}\mathrm{CY} \\
\mathrm{FeOX}\end{array}$ & $\begin{array}{l}\text { dense mat-like aggregate } \\
\text { irregular aggregates, subsperoidal } \\
\text { to botryoidal }\end{array}$ & $\begin{array}{l}<0.002 \\
0.002\end{array}$ & $\begin{array}{l}<0.002 \\
0.002\end{array}$ & $\begin{array}{l}35-40 \\
15-20\end{array}$ & $\begin{array}{l}\text { mat consists of sub } 2 \text { micron } \\
\text { crystals }\end{array}$ \\
\hline $\begin{array}{l}\text { ER-18-2/1970- } \\
1980\end{array}$ & 200 & 100 & 0.02 & $\begin{array}{l}\text { moderately rough } \\
\text { granular with blocky } \\
\text { offsets }\end{array}$ & 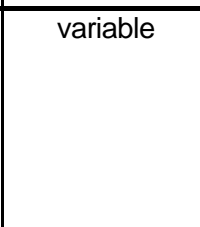 & 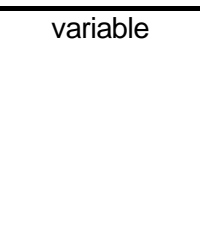 & $<0.01$ & $<0.01$ & 0.01 & $\begin{array}{c}\mathrm{CC} \\
\\
\mathrm{CY} \\
\mathrm{QC} \\
\mathrm{MnOX}\end{array}$ & $\begin{array}{l}\text { irregular, polycrystalline masses } \\
\text { irregular } \\
\text { irregular to blocky crystals } \\
\text { fibrous to prismatic }\end{array}$ & $\begin{array}{l}0.5 \\
\\
0.002 \\
0.002 \\
0.005\end{array}$ & $\begin{array}{l}0.2 \\
\\
0.002 \\
0.002 \\
0.001\end{array}$ & $\begin{array}{l}40-50 \\
30-45 \\
15-20\end{array}$ & $\begin{array}{l}\text { solution pitted, Mn-bearing } \\
\text { matted mixture of smectite/lilite } \\
\text { and chalcedony } \\
\text { Ba-bearing }\end{array}$ \\
\hline $\begin{array}{l}\text { ER-18-2/2050- } \\
2060\end{array}$ & 200 & 75 & $\overline{0.02}$ & $\begin{array}{l}\text { moderately smooth } \\
\text { granular to matted } \\
\text { with dessication } \\
\text { cracks }\end{array}$ & smooth & $\begin{array}{l}\text { typically } \\
\text { rounded }\end{array}$ & $<0.01$ & $<0.01$ & $<0.01$ & $\begin{array}{c}\mathrm{CY} \\
\\
\mathrm{QC} \\
\mathrm{FeOX} \\
\mathrm{MnOX} \\
\end{array}$ & $\begin{array}{l}\text { subhedral to euhedral blocks and } \\
\text { cubes } \\
\text { iribegular aggregates } \\
\text { radiating prismatic aggregates }\end{array}$ & $\begin{array}{l}0.01 \\
0.01 \\
0.01\end{array}$ & $\begin{array}{l}0.008 \\
0.003 \\
0.002\end{array}$ & $\begin{array}{c}50 \\
\\
10 \\
10-15 \\
\text { tr } \\
\end{array}$ & $\begin{array}{l}\text { probable smectite likely to be inter } \\
\text { grown with chalcedony }\end{array}$ \\
\hline
\end{tabular}




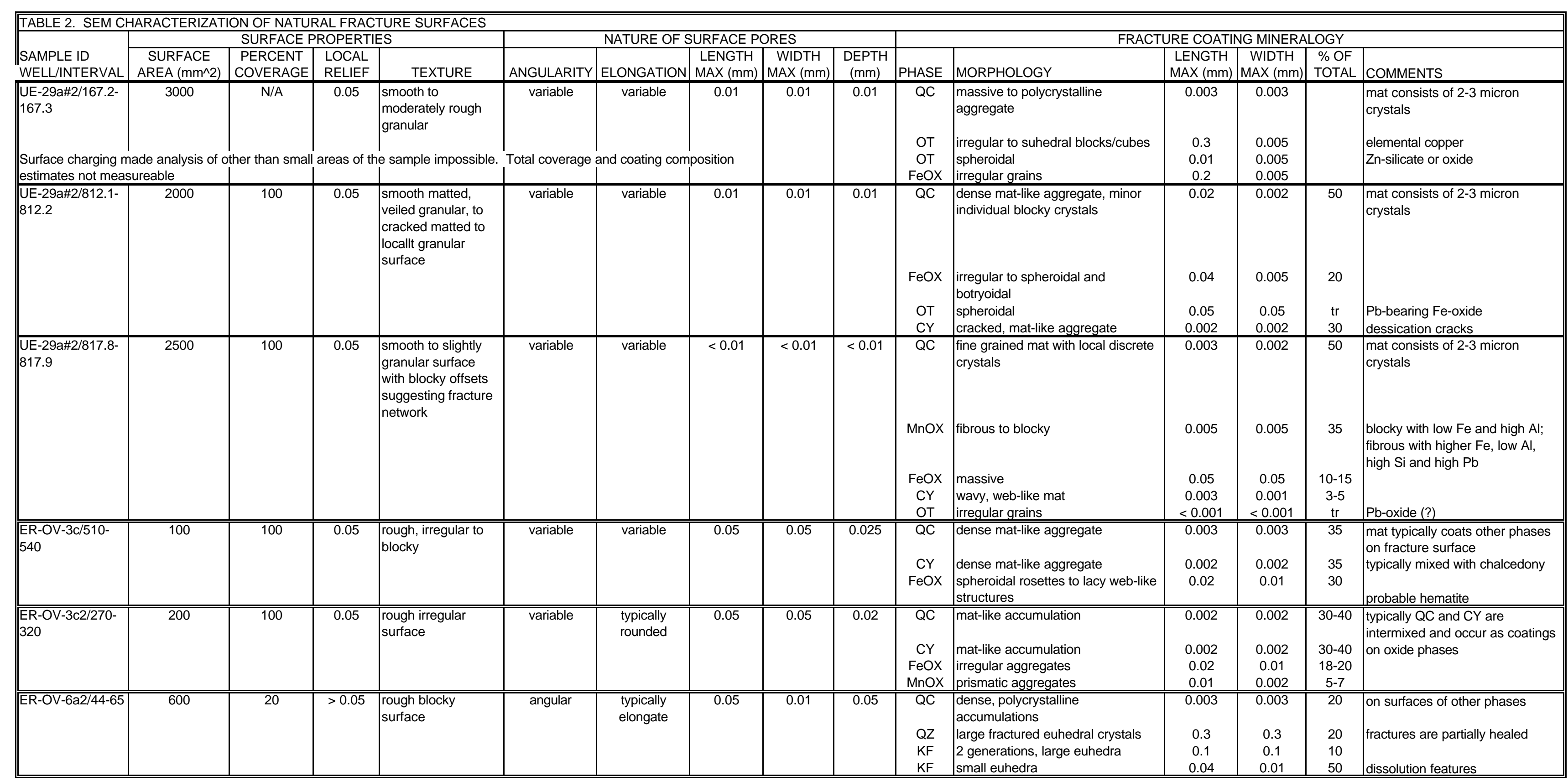




\begin{tabular}{|c|c|c|c|c|c|c|c|}
\hline sample & $\begin{array}{l}\text { depth } \\
\text { (m) }\end{array}$ & $\begin{array}{c}\text { yield }(\%) \\
\left(\text { as } \mathrm{CaCO}_{3}\right)\end{array}$ & $\begin{array}{c}\delta^{13} \mathrm{C} \\
(\% \circ \text { PDB })\end{array}$ & $\begin{array}{c}\delta^{18} \mathrm{O} \\
(\% \text { SMOW) }\end{array}$ & $\begin{array}{l}\text { Temp ( }{ }^{\circ} \mathrm{C} \text { ) for } \\
\delta^{18} \mathrm{O}_{\mathrm{w}}=-15.0\end{array}$ & $\begin{array}{l}\text { Temp }\left({ }^{\circ} \mathrm{C}\right) \text { for } \\
\delta^{18} \mathrm{O}_{w}=-12.5\end{array}$ & $\begin{array}{l}\text { Temp }\left({ }^{\circ} \mathrm{C}\right) \text { for } \\
\delta^{18} \mathrm{O}_{\mathrm{w}}=-10.0\end{array}$ \\
\hline NBS-18 (reference standard) & - & 96.6 & -5.04 & 7.16 & - & - & - \\
\hline NBS-19 (reference standard) & - & 98.3 & 1.96 & 28.66 & - & - & - \\
\hline NBS-20 (reference standard) & - & 91.5 & -1.07 & 26.63 & - & - & - \\
\hline ER-EC-1 $3480-3490 \mathrm{ft}$ & $1060.7-1063.8$ & 9.5 & 3.24 & 5.89 & 68 & 88 & 111 \\
\hline ER-EC-1 $\quad 4520-4540 \mathrm{ft}$ & $1377.7-1383.8$ & 97.7 & 2.59 & 2.73 & 93 & 118 & 148 \\
\hline ER-EC-1 $\quad 4570-4580 \mathrm{ft}$ & $1392.9-1396.0$ & 91.9 & 2.32 & 2.62 & 94 & 119 & 150 \\
\hline ER-EC-4 960-970 ft & $292.6-295.7$ & 81.9 & -6.73 & 16.01 & 13 & 25 & 37 \\
\hline ER-EC-4 $1150-1160 \mathrm{ft}$ & $350.5-353.6$ & 88.6 & -7.50 & 15.49 & 15 & 27 & 40 \\
\hline ER-EC-4 $1920-1930 \mathrm{ft}$ & $585.2-588.3$ & 68.4 & 4.56 & 8.76 & 49 & 66 & 85 \\
\hline ER-EC-4 2210-2220 ft & $673.6-676.7$ & 96.5 & -4.75 & 15.24 & 17 & 28 & 42 \\
\hline ER-EC-5 $\quad 1190-1210 \mathrm{ft}$ & $362.7-368.8$ & 71.1 & 2.70 & 0.32 & 116 & 146 & 185 \\
\hline ER-EC-5 $1900-1910 \mathrm{ft}$ & $579.1-582.2$ & 89.9 & 2.82 & 6.96 & 61 & 79 & 101 \\
\hline ER-EC-5 $2380-2390 \mathrm{ft}$ & $725.4-728.5$ & 86.4 & 1.88 & 6.74 & 62 & 81 & 103 \\
\hline ER-EC-6 $2230-2250 \mathrm{ft}$ & $679.7-685.8$ & 75.9 & 3.11 & 4.51 & 78 & 100 & 126 \\
\hline ER-EC-6 $3420-3440 \mathrm{ft}$ & $1042.4-1048.5$ & 96.7 & 2.22 & 1.17 & 108 & 136 & 171 \\
\hline ER-EC-7 1180-1200 ft & $359.7-365.8$ & 99.4 & -1.77 & 14.30 & 21 & 33 & 47 \\
\hline ER-EC-8 $1850-1870 \mathrm{ft}$ & $563.9-570.0$ & 96.9 & -2.24 & 10.85 & 38 & 52 & 69 \\
\hline ER-18-2 2050-2080 ft & $624.8-634.0$ & 96.6 & -0.87 & 9.85 & 43 & 59 & 76 \\
\hline ER-OV-3a $20 \mathrm{ft}$ & 6.1 & 1.3 & -3.24 & 20.52 & -4 & 6 & 16 \\
\hline ER-30-1 $580-610 \mathrm{ft}$ & $176.8-185.9$ & 64.9 & 0.11 & 13.89 & 23 & 35 & 49 \\
\hline ER-30-1 $750-760 \mathrm{ft}$ & $228.6-231.6$ & 40.3 & 1.58 & 19.42 & 0 & 10 & 21 \\
\hline
\end{tabular}




\begin{tabular}{|c|c|c|c|c|c|c|c|c|}
\hline Sample ID: & ER-EC-4 (a) & ER-EC-4 (b) & ER-EC-6 & ER-EC-8 & ER-18-2 & ER-30-1 & ER-OV-3a & ER-OV-3a-Dup \\
\hline Interval & $\begin{array}{c}1150-1160 \mathrm{ft} \\
\text { Conc. (ppm) } \\
\text { Std. Dev. }\end{array}$ & $\begin{array}{c}2210-2220 \mathrm{ft} \\
\text { Conc. (ppm) } \\
\text { Std. Dev. }\end{array}$ & $\begin{array}{c}\text { 3420-3440 ft } \\
\text { Conc. (ppm) } \\
\text { Std. Dev. }\end{array}$ & $\begin{array}{c}1850-1870 \mathrm{ft} \\
\text { Conc. (ppm) } \\
\text { Std. Dev. }\end{array}$ & $\begin{array}{l}\text { 2050-2080 ft } \\
\text { Conc. (ppm) } \\
\text { Std. Dev. }\end{array}$ & $\begin{array}{l}750-760 \mathrm{ft} \\
\text { Conc. (ppm) } \\
\text { Std. Dev. } \\
\end{array}$ & $\begin{array}{c}20 \mathrm{ft} \\
\text { Conc. (ppm) } \\
\text { Std. Dev. } \\
\end{array}$ & $\begin{array}{c}20 \mathrm{ft} \\
\text { Conc. (ppm) } \\
\text { Std. Dev. }\end{array}$ \\
\hline Y 89 & $\begin{array}{c}8.209 \mathrm{E}+00 \\
1.589 \mathrm{E}-01\end{array}$ & $\begin{array}{c}4.336 \mathrm{E}+00 \\
1.995 \mathrm{E}-01\end{array}$ & $\begin{array}{l}1.192 \mathrm{E}+02 \\
5.346 \mathrm{E}+00\end{array}$ & $\begin{array}{l}2.042 \mathrm{E}+01 \\
8.817 \mathrm{E}-01\end{array}$ & $\begin{array}{c}2.504 \mathrm{E}+01 \\
2.114 \mathrm{E}-01\end{array}$ & $\begin{array}{l}1.511 \mathrm{E}+01 \\
3.470 \mathrm{E}-01\end{array}$ & $\begin{array}{l}1.782 \mathrm{E}+01 \\
3.147 \mathrm{E}-01\end{array}$ & $\begin{array}{l}1.724 \mathrm{E}+01 \\
6.946 \mathrm{E}-01\end{array}$ \\
\hline La 139 & $\begin{array}{l}1.827 \mathrm{E}+00 \\
2.666 \mathrm{E}-02\end{array}$ & $\begin{array}{l}1.910 \mathrm{E}+00 \\
6.964 \mathrm{E}-02\end{array}$ & $\begin{array}{l}2.125 \mathrm{E}+01 \\
1.152 \mathrm{E}-01\end{array}$ & $\begin{array}{l}3.110 \mathrm{E}+01 \\
3.321 \mathrm{E}-01\end{array}$ & $\begin{array}{l}2.044 \mathrm{E}+01 \\
2.641 \mathrm{E}-01\end{array}$ & $\begin{array}{l}3.259 \mathrm{E}+01 \\
1.210 \mathrm{E}+00\end{array}$ & $\begin{array}{l}4.033 \mathrm{E}+01 \\
7.904 \mathrm{E}-01\end{array}$ & $\begin{array}{l}3.850 \mathrm{E}+01 \\
9.794 \mathrm{E}-01\end{array}$ \\
\hline Ce 140 & $\begin{array}{c}4.386 \mathrm{E}-01 \\
-2.716 \mathrm{E}-03\end{array}$ & $\begin{array}{c}2.773 \mathrm{E}+00 \\
1.353 \mathrm{E}-01\end{array}$ & $\begin{array}{l}5.308 \mathrm{E}+01 \\
7.070 \mathrm{E}-01\end{array}$ & $\begin{array}{l}6.374 \mathrm{E}-01 \\
8.280 \mathrm{E}-03\end{array}$ & $\begin{array}{l}2.268 \mathrm{E}+01 \\
2.952 \mathrm{E}-01\end{array}$ & $\begin{array}{l}5.716 \mathrm{E}+01 \\
8.273 \mathrm{E}-01\end{array}$ & $\begin{array}{l}8.410 \mathrm{E}+01 \\
1.120 \mathrm{E}+00\end{array}$ & $\begin{array}{l}8.022 \mathrm{E}+01 \\
2.791 \mathrm{E}+00\end{array}$ \\
\hline $\operatorname{Pr} 141$ & $\begin{array}{l}9.236 \mathrm{E}-01 \\
6.053 \mathrm{E}-03\end{array}$ & $\begin{array}{l}5.034 \mathrm{E}-01 \\
8.118 \mathrm{E}-03\end{array}$ & $\begin{array}{c}1.098 \mathrm{E}+01 \\
1.980 \mathrm{E}-01\end{array}$ & $\begin{array}{c}8.928 \mathrm{E}+00 \\
1.416 \mathrm{E}-01\end{array}$ & $\begin{array}{c}3.574 \mathrm{E}+00 \\
5.784 \mathrm{E}-02\end{array}$ & $\begin{array}{c}7.417 \mathrm{E}+00 \\
1.193 \mathrm{E}-01\end{array}$ & $\begin{array}{l}9.877 \mathrm{E}+00 \\
3.609 \mathrm{E}-01\end{array}$ & $\begin{array}{l}1.028 \mathrm{E}+01 \\
2.467 \mathrm{E}-01\end{array}$ \\
\hline Nd 143 & $\begin{array}{l}4.535 \mathrm{E}+00 \\
7.944 \mathrm{E}-02\end{array}$ & $\begin{array}{l}1.983 \mathrm{E}+00 \\
7.133 \mathrm{E}-02\end{array}$ & $\begin{array}{c}3.424 \mathrm{E}+01 \\
9.350 \mathrm{E}-01\end{array}$ & $\begin{array}{l}2.467 \mathrm{E}+01 \\
8.910 \mathrm{E}-01\end{array}$ & $\begin{array}{l}1.224 \mathrm{E}+01 \\
2.605 \mathrm{E}-01\end{array}$ & $\begin{array}{c}2.077 \mathrm{E}+01 \\
5.759 \mathrm{E}-01\end{array}$ & $\begin{array}{l}2.650 \mathrm{E}+01 \\
8.485 \mathrm{E}-01\end{array}$ & $\begin{array}{c}2.513 \mathrm{E}+01 \\
5.640 \mathrm{E}-01\end{array}$ \\
\hline Nd 146 & $\begin{array}{r}4.677 \mathrm{E}+00 \\
3.384 \mathrm{E}-02\end{array}$ & $\begin{array}{r}2.015 \mathrm{E}+00 \\
6.237 \mathrm{E}-02\end{array}$ & $\begin{array}{l}3.456 \mathrm{E}+01 \\
1.351 \mathrm{E}+00\end{array}$ & $\begin{array}{l}2.455 \mathrm{E}+01 \\
2.684 \mathrm{E}-01\end{array}$ & $\begin{array}{l}1.239 \mathrm{E}+01 \\
6.632 \mathrm{E}-02\end{array}$ & $\begin{array}{l}1.994 \mathrm{E}+01 \\
8.786 \mathrm{E}-01\end{array}$ & $\begin{array}{l}2.646 \mathrm{E}+01 \\
1.257 \mathrm{E}+00\end{array}$ & $\begin{array}{c}2.561 \mathrm{E}+01 \\
2.857 \mathrm{E}-01\end{array}$ \\
\hline Sm 147 & $\begin{array}{l}1.172 \mathrm{E}+00 \\
1.620 \mathrm{E}-02\end{array}$ & $\begin{array}{l}3.846 \mathrm{E}-01 \\
1.623 \mathrm{E}-02\end{array}$ & $\begin{array}{l}1.688 \mathrm{E}+01 \\
3.671 \mathrm{E}-01\end{array}$ & $\begin{array}{l}5.866 \mathrm{E}+00 \\
3.815 \mathrm{E}-02\end{array}$ & $\begin{array}{r}2.696 \mathrm{E}+00 \\
4.244 \mathrm{E}-02\end{array}$ & $\begin{array}{l}4.113 \mathrm{E}+00 \\
2.920 \mathrm{E}-02\end{array}$ & $\begin{array}{c}5.666 \mathrm{E}+00 \\
1.125 \mathrm{E}-01\end{array}$ & $\begin{array}{l}5.968 \mathrm{E}+00 \\
7.143 \mathrm{E}-02\end{array}$ \\
\hline Sm 149 & $\begin{array}{l}1.168 \mathrm{E}+00 \\
2.504 \mathrm{E}-02\end{array}$ & $\begin{array}{l}3.800 \mathrm{E}-01 \\
5.202 \mathrm{E}-03\end{array}$ & $\begin{array}{l}1.679 \mathrm{E}+01 \\
3.143 \mathrm{E}-01\end{array}$ & $\begin{array}{l}5.746 \mathrm{E}+00 \\
7.753 \mathrm{E}-02\end{array}$ & $\begin{array}{l}2.702 \mathrm{E}+00 \\
7.526 \mathrm{E}-02\end{array}$ & $\begin{array}{r}4.060 \mathrm{E}+00 \\
6.272 \mathrm{E}-02\end{array}$ & $\begin{array}{c}5.595 \mathrm{E}+00 \\
1.828 \mathrm{E}-01\end{array}$ & $\begin{array}{l}5.907 \mathrm{E}+00 \\
7.128 \mathrm{E}-02\end{array}$ \\
\hline Eu 151 & $\begin{array}{l}2.749 \mathrm{E}-01 \\
9.348 \mathrm{E}-03\end{array}$ & $\begin{array}{l}1.069 \mathrm{E}-01 \\
7.784 \mathrm{E}-03\end{array}$ & $\begin{array}{l}2.570 \mathrm{E}+00 \\
3.928 \mathrm{E}-02\end{array}$ & $\begin{array}{l}3.097 \mathrm{E}-01 \\
8.651 \mathrm{E}-03\end{array}$ & $\begin{array}{l}1.578 \mathrm{E}+00 \\
2.161 \mathrm{E}-02\end{array}$ & $\begin{array}{l}6.223 \mathrm{E}-01 \\
1.998 \mathrm{E}-02\end{array}$ & $\begin{array}{l}9.696 \mathrm{E}-01 \\
3.774 \mathrm{E}-02\end{array}$ & $\begin{array}{l}1.006 \mathrm{E}+00 \\
5.332 \mathrm{E}-03\end{array}$ \\
\hline Eu 153 & $\begin{array}{l}2.749 \mathrm{E}-01 \\
1.592 \mathrm{E}-02\end{array}$ & $\begin{array}{l}1.067 \mathrm{E}-01 \\
3.665 \mathrm{E}-03\end{array}$ & $\begin{array}{l}2.634 \mathrm{E}+00 \\
3.799 \mathrm{E}-02\end{array}$ & $\begin{array}{l}3.012 \mathrm{E}-01 \\
3.132 \mathrm{E}-03\end{array}$ & $\begin{array}{l}1.595 \mathrm{E}+00 \\
2.468 \mathrm{E}-02\end{array}$ & $\begin{array}{l}6.452 \mathrm{E}-01 \\
2.463 \mathrm{E}-02\end{array}$ & $\begin{array}{l}1.014 \mathrm{E}+00 \\
3.670 \mathrm{E}-02\end{array}$ & $\begin{array}{l}1.046 \mathrm{E}+00 \\
1.878 \mathrm{E}-02\end{array}$ \\
\hline Gd 157 & $\begin{array}{l}1.287 \mathrm{E}+00 \\
6.145 \mathrm{E}-02\end{array}$ & $\begin{array}{l}4.737 \mathrm{E}-01 \\
2.741 \mathrm{E}-02\end{array}$ & $\begin{array}{l}1.973 \mathrm{E}+01 \\
3.716 \mathrm{E}-01\end{array}$ & $\begin{array}{c}5.081 \mathrm{E}+00 \\
1.065 \mathrm{E}-01\end{array}$ & $\begin{array}{r}3.261 \mathrm{E}+00 \\
1.598 \mathrm{E}-02\end{array}$ & $\begin{array}{l}3.841 \mathrm{E}+00 \\
1.546 \mathrm{E}-01\end{array}$ & $\begin{array}{l}5.120 \mathrm{E}+00 \\
8.923 \mathrm{E}-02\end{array}$ & $\begin{array}{l}5.282 \mathrm{E}+00 \\
6.029 \mathrm{E}-02\end{array}$ \\
\hline
\end{tabular}




\begin{tabular}{|c|c|c|c|c|c|c|c|c|}
\hline Sample ID: & ER-EC-4 (a) & ER-EC-4 (b) & ER-EC-6 & ER-EC-8 & ER-18-2 & ER-30-1 & ER-OV-3a & ER-OV-3a-Dup \\
\hline Interval & $\begin{array}{c}1150-1160 \mathrm{ft} \\
\text { Conc. (ppm) } \\
\text { Std. Dev. }\end{array}$ & $\begin{array}{l}\text { 2210-2220 ft } \\
\text { Conc. (ppm) } \\
\text { Std. Dev. }\end{array}$ & $\begin{array}{c}3420-3440 \mathrm{ft} \\
\text { Conc. (ppm) } \\
\text { Std. Dev. }\end{array}$ & $\begin{array}{c}1850-1870 \mathrm{ft} \\
\text { Conc. (ppm) } \\
\text { Std. Dev. }\end{array}$ & $\begin{array}{c}\text { 2050-2080 ft } \\
\text { Conc. (ppm) } \\
\text { Std. Dev. }\end{array}$ & $\begin{array}{c}750-760 \mathrm{ft} \\
\text { Conc. (ppm) } \\
\text { Std. Dev. }\end{array}$ & $\begin{array}{c}20 \mathrm{ft} \\
\text { Conc. (ppm) } \\
\text { Std. Dev. } \\
\end{array}$ & $\begin{array}{c}20 \mathbf{f t} \\
\text { Conc. (ppm) } \\
\text { Std. Dev. } \\
\end{array}$ \\
\hline Gd 158 & $\begin{array}{l}1.392 \mathrm{E}+00 \\
2.083 \mathrm{E}-02\end{array}$ & $\begin{array}{l}4.771 \mathrm{E}-01 \\
1.689 \mathrm{E}-02\end{array}$ & $\begin{array}{l}1.524 \mathrm{E}+01 \\
4.000 \mathrm{E}-01\end{array}$ & $\begin{array}{c}5.250 \mathrm{E}+00 \\
1.543 \mathrm{E}-01\end{array}$ & $\begin{array}{l}3.582 \mathrm{E}+00 \\
7.829 \mathrm{E}-02\end{array}$ & $\begin{array}{l}3.962 \mathrm{E}+00 \\
9.243 \mathrm{E}-02\end{array}$ & $\begin{array}{c}5.343 \mathrm{E}+00 \\
1.184 \mathrm{E}-01\end{array}$ & $\begin{array}{l}5.472 \mathrm{E}+00 \\
7.597 \mathrm{E}-02\end{array}$ \\
\hline Tb 159 & $\begin{array}{l}2.200 \mathrm{E}-01 \\
6.153 \mathrm{E}-03\end{array}$ & $\begin{array}{l}8.650 \mathrm{E}-02 \\
2.088 \mathrm{E}-03\end{array}$ & $\begin{array}{l}3.968 \mathrm{E}+00 \\
8.249 \mathrm{E}-02\end{array}$ & $\begin{array}{l}6.915 \mathrm{E}-01 \\
8.227 \mathrm{E}-03\end{array}$ & $\begin{array}{l}\text { 6.622E-01 } \\
2.166 \mathrm{E}-02\end{array}$ & $\begin{array}{l}5.576 \mathrm{E}-01 \\
4.652 \mathrm{E}-03\end{array}$ & $\begin{array}{l}\text { 7.394E-01 } \\
1.787 \mathrm{E}-02\end{array}$ & $\begin{array}{l}\text { 7.959E-01 } \\
1.961 \mathrm{E}-02\end{array}$ \\
\hline Dy 161 & $\begin{array}{l}1.315 \mathrm{E}+00 \\
2.766 \mathrm{E}-02\end{array}$ & $\begin{array}{l}5.920 \mathrm{E}-01 \\
1.783 \mathrm{E}-02\end{array}$ & $\begin{array}{l}1.672 \mathrm{E}+01 \\
4.830 \mathrm{E}-01\end{array}$ & $\begin{array}{l}3.517 \mathrm{E}+00 \\
7.395 \mathrm{E}-02\end{array}$ & $\begin{array}{r}4.308 \mathrm{E}+00 \\
9.134 \mathrm{E}-02\end{array}$ & $\begin{array}{r}3.184 \mathrm{E}+00 \\
4.980 \mathrm{E}-02\end{array}$ & $\begin{array}{r}4.236 \mathrm{E}+00 \\
9.354 \mathrm{E}-02\end{array}$ & $\begin{array}{c}4.458 \mathrm{E}+00 \\
1.425 \mathrm{E}-01\end{array}$ \\
\hline Dy 163 & $\begin{array}{l}1.305 \mathrm{E}+00 \\
5.824 \mathrm{E}-02\end{array}$ & $\begin{array}{l}5.896 \mathrm{E}-01 \\
8.261 \mathrm{E}-03\end{array}$ & $\begin{array}{l}1.607 \mathrm{E}+01 \\
6.823 \mathrm{E}-01\end{array}$ & $\begin{array}{r}3.195 \mathrm{E}+00 \\
1.336 \mathrm{E}-02\end{array}$ & $\begin{array}{r}4.198 \mathrm{E}+00 \\
6.471 \mathrm{E}-02\end{array}$ & $\begin{array}{c}3.012 \mathrm{E}+00 \\
1.130 \mathrm{E}-01\end{array}$ & $\begin{array}{r}4.001 \mathrm{E}+00 \\
6.797 \mathrm{E}-02\end{array}$ & $\begin{array}{r}4.216 \mathrm{E}+00 \\
5.214 \mathrm{E}-02\end{array}$ \\
\hline Ho 165 & $\begin{array}{l}2.687 \mathrm{E}-01 \\
5.613 \mathrm{E}-03\end{array}$ & $\begin{array}{l}1.428 \mathrm{E}-01 \\
2.825 \mathrm{E}-03\end{array}$ & $\begin{array}{l}4.356 \mathrm{E}+00 \\
7.140 \mathrm{E}-02\end{array}$ & $\begin{array}{l}6.000 \mathrm{E}-01 \\
2.289 \mathrm{E}-02\end{array}$ & $\begin{array}{l}8.867 \mathrm{E}-01 \\
1.922 \mathrm{E}-02\end{array}$ & $\begin{array}{l}6.196 \mathrm{E}-01 \\
8.159 \mathrm{E}-03\end{array}$ & $\begin{array}{l}\text { 7.787E-01 } \\
3.012 \mathrm{E}-02\end{array}$ & $\begin{array}{l}8.350 \mathrm{E}-01 \\
2.080 \mathrm{E}-02\end{array}$ \\
\hline Er 166 & $\begin{array}{l}7.656 \mathrm{E}-01 \\
1.716 \mathrm{E}-02\end{array}$ & $\begin{array}{l}4.583 \mathrm{E}-01 \\
1.752 \mathrm{E}-02\end{array}$ & $\begin{array}{l}1.070 \mathrm{E}+01 \\
2.749 \mathrm{E}-01\end{array}$ & $\begin{array}{l}1.576 \mathrm{E}+00 \\
3.441 \mathrm{E}-02\end{array}$ & $\begin{array}{r}2.554 \mathrm{E}+00 \\
9.908 \mathrm{E}-02\end{array}$ & $\begin{array}{l}1.915 \mathrm{E}+00 \\
3.438 \mathrm{E}-02\end{array}$ & $\begin{array}{r}2.303 E+00 \\
5.852 E-02\end{array}$ & $\begin{array}{r}2.537 \mathrm{E}+00 \\
5.200 \mathrm{E}-02\end{array}$ \\
\hline Er 167 & $\begin{array}{l}7.664 \mathrm{E}-01 \\
9.294 \mathrm{E}-03\end{array}$ & $\begin{array}{l}4.641 \mathrm{E}-01 \\
1.076 \mathrm{E}-02\end{array}$ & $\begin{array}{l}1.066 \mathrm{E}+01 \\
3.263 \mathrm{E}-01\end{array}$ & $\begin{array}{l}1.554 \mathrm{E}+00 \\
2.817 \mathrm{E}-02\end{array}$ & $\begin{array}{r}2.541 \mathrm{E}+00 \\
3.014 \mathrm{E}-02\end{array}$ & $\begin{array}{l}1.860 \mathrm{E}+00 \\
2.718 \mathrm{E}-02\end{array}$ & $\begin{array}{r}2.299 \mathrm{E}+00 \\
3.229 \mathrm{E}-02\end{array}$ & $\begin{array}{r}2.484 \mathrm{E}+00 \\
3.264 \mathrm{E}-02\end{array}$ \\
\hline Tm 169 & $\begin{array}{l}1.002 \mathrm{E}-01 \\
2.521 \mathrm{E}-03\end{array}$ & $\begin{array}{l}6.633 \mathrm{E}-02 \\
1.710 \mathrm{E}-03\end{array}$ & $\begin{array}{l}1.357 \mathrm{E}+00 \\
4.458 \mathrm{E}-02\end{array}$ & $\begin{array}{l}1.954 \mathrm{E}-01 \\
6.978 \mathrm{E}-03\end{array}$ & $\begin{array}{l}3.706 \mathrm{E}-01 \\
7.166 \mathrm{E}-03\end{array}$ & $\begin{array}{l}2.922 \mathrm{E}-01 \\
1.542 \mathrm{E}-03\end{array}$ & $\begin{array}{l}3.533 \mathrm{E}-01 \\
1.271 \mathrm{E}-02\end{array}$ & $\begin{array}{l}3.831 \mathrm{E}-01 \\
3.791 \mathrm{E}-03\end{array}$ \\
\hline Yb 173 & $\begin{array}{l}5.460 \mathrm{E}-01 \\
1.411 \mathrm{E}-02\end{array}$ & $\begin{array}{l}3.661 \mathrm{E}-01 \\
1.341 \mathrm{E}-02\end{array}$ & $\begin{array}{c}7.506 \mathrm{E}+00 \\
1.642 \mathrm{E}-01\end{array}$ & $\begin{array}{l}1.099 \mathrm{E}+00 \\
6.529 \mathrm{E}-03\end{array}$ & $\begin{array}{c}2.269 \mathrm{E}+00 \\
4.691 \mathrm{E}-02\end{array}$ & $\begin{array}{l}1.930 \mathrm{E}+00 \\
6.765 \mathrm{E}-02\end{array}$ & $\begin{array}{l}2.340 \mathrm{E}+00 \\
7.913 \mathrm{E}-02\end{array}$ & $\begin{array}{r}2.568 \mathrm{E}+00 \\
4.880 \mathrm{E}-02\end{array}$ \\
\hline Yb 174 & $\begin{array}{l}5.524 \mathrm{E}-01 \\
1.572 \mathrm{E}-02\end{array}$ & $\begin{array}{l}3.780 \mathrm{E}-01 \\
7.478 \mathrm{E}-03\end{array}$ & $\begin{array}{l}7.515 \mathrm{E}+00 \\
5.743 \mathrm{E}-02\end{array}$ & $\begin{array}{l}1.096 \mathrm{E}+00 \\
1.203 \mathrm{E}-02\end{array}$ & $\begin{array}{l}2.364 \mathrm{E}+00 \\
7.330 \mathrm{E}-02\end{array}$ & $\begin{array}{l}1.940 \mathrm{E}+00 \\
4.312 \mathrm{E}-02\end{array}$ & $\begin{array}{c}2.370 \mathrm{E}+00 \\
1.087 \mathrm{E}-01\end{array}$ & $\begin{array}{r}2.630 \mathrm{E}+00 \\
2.046 \mathrm{E}-02\end{array}$ \\
\hline Lu 175 & $\begin{array}{l}7.201 \mathrm{E}-02 \\
1.684 \mathrm{E}-02\end{array}$ & $\begin{array}{l}4.417 \mathrm{E}-02 \\
1.817 \mathrm{E}-02\end{array}$ & $\begin{array}{l}8.737 \mathrm{E}-01 \\
2.343 \mathrm{E}-02\end{array}$ & $\begin{array}{l}1.423 \mathrm{E}-01 \\
1.791 \mathrm{E}-02\end{array}$ & $\begin{array}{l}3.561 \mathrm{E}-01 \\
1.768 \mathrm{E}-02\end{array}$ & $\begin{array}{l}2.768 \mathrm{E}-01 \\
1.930 \mathrm{E}-02\end{array}$ & $\begin{array}{l}3.523 \mathrm{E}-01 \\
2.431 \mathrm{E}-02\end{array}$ & $\begin{array}{l}3.924 \mathrm{E}-01 \\
1.819 \mathrm{E}-02\end{array}$ \\
\hline Th 232 & $\begin{array}{l}3.971 \mathrm{E}-02 \\
6.246 \mathrm{E}-04\end{array}$ & $\begin{array}{l}3.283 \mathrm{E}-01 \\
1.490 \mathrm{E}-03\end{array}$ & $\begin{array}{c}6.388 \mathrm{E}-01 \\
-6.962 \mathrm{E}-04\end{array}$ & $\begin{array}{l}3.342 \mathrm{E}-01 \\
9.518 \mathrm{E}-03\end{array}$ & $\begin{array}{l}5.799 \mathrm{E}-01 \\
1.493 \mathrm{E}-02\end{array}$ & $\begin{array}{l}1.342 \mathrm{E}+01 \\
4.464 \mathrm{E}-01\end{array}$ & $\begin{array}{r}2.244 \mathrm{E}+01 \\
3.279 \mathrm{E}-01\end{array}$ & $\begin{array}{r}2.272 \mathrm{E}+01 \\
3.063 \mathrm{E}-01\end{array}$ \\
\hline
\end{tabular}


Appendix 1 


\section{Appendix 1}

\section{Description of Samples Analyzed Using SEM-EDS}

All descriptions are for samples obtained from drill cuttings, cores, and sidewall cores. Stratigraphic assignments for the ER-EC wells and ER-18-2 are based on lithologic logs provided by Lance Prothro (Bechtel Nevada; written communication, 1999). Stratigraphic assignments for the ER-OV wells are taken from Robledo et al (1998). Stratigraphic assignment for the samples from UE-29a\#2 have been provided by Rick Warren (LANL, written communication, 2000).

\section{Drill Hole ER-EC-1}

\section{Sample 2389}

\section{$\underline{\text { General Description }}$}

This material is described (Table 1) as devitrified Rhyolite of Benham. This material comprises a lava flow aquifer within the Upper Paintbrush (Drellack and Prothro, 1997).

The exposed fracture is an irregular surface, and is one of multiple thin $(<0.2 \mathrm{~mm})$, irregular, and intersecting open fractures that are observed in this sidewall core. The fractures in this sample exhibit limited development of fracture coating phases.

\section{$\underline{\text { Scanning Electron Microscopy }}$}

SEM evaluation (Table 2) shows the exposed fracture surface to be variable. Relief is on the order of $0.1 \mathrm{~mm}$ or more with abundant areas of negative relief that range from rounded to angular and from roughly equidimensional to highly elongate. Approximately 30 to 40 percent of the fracture surface is coated with a weakly developed granular to 'mat-like' covering comprised of 15 to 20 percent chalcedony and 8 to 10 percent illite clay, with 3 to 5 percent Fe-oxide minerals as irregular aggregates and disseminated grains on the fracture surface. No images of this sample are included in this report.

\section{Sample 2480-2490}

\section{$\underline{\text { General Description }}$}

This material is described (Table 1) as devitrified Rhyolite of Benham. This material comprises a lava flow aquifer within the Upper Paintbrush (Drellack and Prothro, 1997).

The exposed fracture is a small irregular surface observed in this drill cuttings fragment. The fracture in this sample exhibits strong development of fracture coating phases. While this sample comes from an interval that is generally equivalent to that from which 
the sample collected at the 2389-foot depth interval was taken, the coatings on this sample are dominated by eroded feldspar crystals with lesser chalcedony and oxide phases. This specific sample likely reflects a distinct zone of alteration originally associated with higher temperature processes than the phases observed in sample 2389 from ER-EC-1. Observations do identify solutions features in the fracture-coating feldspar crystals indicating that retrograde processes have affected this sample.

\section{$\underline{\text { Scanning Electron Microscopy }}$}

SEM evaluation (Table 2) shows the exposed fracture surface to be rough and variable. Surface relief is greater than $0.1 \mathrm{~mm}$ with abundant areas of negative relief (up to 100 $\mu \mathrm{m})$ with variable morphology. Approximately 90 percent of the fracture surface is coated. The coating is dominated by blocky to tabular feldspar crystals that have been strongly eroded by solution processes (Figure 1 and Figure 2). A finer accumulation of chalcedony, Fe- and Mn-oxides, and clay minerals is present between the feldspar crystals (Figure 1 and Figure 3). The Mn-oxide is present as small, fibrous to acicular crystals sparsely but widely distributed across the sample surface (Figures 2 and 3). The Fe-oxide tends to occur as isolated spheres and thick, botryoidal accumulations (Figure 4) that appear to have formed late in the paragenetic sequence.

\section{$\underline{\text { Sample 2800-2810 }}$}

\section{$\underline{\text { General Description }}$}

This material is described (Table 1) as devitrified welded tuff of the Pahute Mesa lobe of the Tiva Canyon Tuff. This material comprises a welded tuff aquifer within the Upper Paintbrush (Drellack and Prothro, 1997).

The exposed fracture is a small irregular surface observed in this drill cuttings fragment. The fracture in this sample exhibits moderately developed fracture coating phases and is likely to represent a largely filled, rather than an open aperture. Observations indicate that the fracture coating is comprised primarily of chalcedony and clay with minor Mn-oxide.

\section{$\underline{\text { Scanning Electron Microscopy }}$}

SEM evaluation (Table 2) shows the fracture surface to be generally smooth (matted to granular) where coated with secondary phases and blocky where uncoated. Surface relief is on the order of $0.05 \mathrm{~mm}$ with sub-rounded areas of negative relief up to $0.01 \mathrm{~mm}$ that predominate in the matted portion of the surface coating. Approximately 40 to 50 percent of the fracture surface is coated with a granular to 'mat-like' covering (Figures 5 and 6) comprised of 20 to 25 percent chalcedony, 10 to 15 percent illite, and 5 to 10 percent smectite. Mn-oxides occur as fine grained to massive polycrystalline accumulations. The matted fracture surface appears to be relatively porous (Figures 6

and 7). The presence of significant cracks within the smectite-rich matted fracture 
coating material (Figure 6) suggest that the fracture coating typically water and has dried out since the samples were collected.

\section{$\underline{\text { Sample } 4530}$}

\section{$\underline{\text { General Description }}$}

This material is described (Table 1) as quartzofeldspathic altered lava of the Volcanics of Quartz Mountain. This material comprises a lava flow aquifer within the Pre-Belted Range Composite Unit (Drellack and Prothro, 1997).

The fracture of interest is a partially exposed, largely filled fracture intersected on the surface of an intact sidewall core. The fracture is a thick $(4-8 \mathrm{~mm})$, irregular fracture, filled with a porous mixture of predominantly clay minerals with lesser Fe-oxide.

\section{Scanning Electron Microscopy}

SEM evaluation (Table 2) shows the largely filled fracture to be comprised primarily of clay with local Fe-oxide (Figure 8). Local relief is greater than $0.1 \mathrm{~mm}$ and the fracture filling material appears to have significant porosity. Approximately 1 to 2 percent of the fracture surface is covered with Fe-oxide (Figures 8-10) with morphologies that vary from sub-spheroidal to botryoidal to dendritic to massive. The remainder of the fracture filling is comprised of clay minerals that are probably smectite group based on the weblike morphology (Figure 10).

\section{Drill Hole ER-EC-4}

\section{$\underline{\text { Sample } 1298}$}

\section{$\underline{\text { General Description }}$}

This material is described (Table 1) as devitrified and zeolitized lava of the Trachyte of Ribbon Cliff. This material comprises a lava flow aquifer within the Thirsty Canyon Group of the Timber Mountain Aquifer (Drellack and Prothro, 1997).

The fracture of interest is an exposed surface on an otherwise intact sidewall core. The fracture is poorly coated with a thin mixture of chalcedony and clay.

\section{$\underline{\text { Scanning Electron Microscopy }}$}

SEM evaluation (Table 2) shows the fracture surface to be very sparsely coated (20\%) with a thin mixture of chalcedony and clay. There is little indication that significant watter-rock interaction has taken place on this fracture surface. No images of this sample are included in this report.

\section{Sample 1910-1920}




\section{$\underline{\text { General Description }}$}

This sample (Table 1) is a cuttings fragment of zeolitized tuff from the Rhyolite of Beatty Wash comprising a tuff confining unit of the Timber Mountain Composite Unit (Drellack and Prothro, 1997).

\section{$\underline{\text { Scanning Electron Microscopy }}$}

SEM evaluation (Table 2) shows the sample surface to be coated entirely by relatively coarse intergrown euhedral zeolite crystals. Morphology (Figure 11) and EDS spectra suggest that these crystals are the mineral heulandite. The sample surface is rough and irregular. The small sample size combined with source from drill cuttings makes the determination as to whether the sample represents a fracture surface or vug filling inconclusive.

\section{$\underline{\text { Sample 2030-2040 }}$}

\section{General Description}

This sample (Table 1) is a cuttings fragment of quartzofeldspathic altered welded tuff from the mafic-poor Ammonia Tanks Tuff comprising a welded tuff aquifer of the Timber Mountain Aquifer (Drellack and Prothro, 1997).

\section{$\underline{\text { Scanning Electron Microscopy }}$}

SEM evaluation (Table 2) shows the sample to have a rough vuggy surface entirely coated by a variety of mineral phases including dolomite, Fe-oxide, zeolite, and chalcedony. As shown in Figure 12, the sample surface consists of both vuggy cavities and the inter-cavity surfaces. The vugs are filled primarily with dolomite and lesser zeolite (Figure 13). Morphology and EDS spectra suggest that the zeolite present is clinoptilolite. The vug lining dolomite (Figure 14) is widespread, occurs in multiple generations and exhibits an irregular pitted surface suggesting dissolution. The intercavity surface (Figure 15) is covered by dendritic Fe-oxide with euhedral zeolite (probable clinoptilolite) and minor chalcedony.

\section{Sample 2110-2120}

\section{$\underline{\text { General Description }}$}

This sample (Table 1) is a cuttings fragment of quartzofeldspathic altered welded tuff from the mafic-poor Ammonia Tanks Tuff comprising a welded tuff aquifer of the Timber Mountain Aquifer (Drellack and Prothro, 1997).

\section{$\underline{\text { Scanning Electron Microscopy }}$}


SEM evaluation (Table 2) reveals the fracture surface to be variable in texture and mineralogy (Figure 16). The fine grained polycrystalline to massive nature of the fracture coating minerals suggests that the fracture observed is likely to be filled and not presently have a significant open aperture. The fracture coating minerals observed include chalcedony (75\%), a Ba-bearing Mn-oxide (Hollandite?, 20\%), and Fe-oxide (5\%), with minor amounts of (probably smectite) minerals. These minerals occur in discrete accumulations and as largely chaotic mixtures on the fracture surface (Figures 17 and 18).

\section{Sample 2240-2250}

\section{$\underline{\text { General Description }}$}

This sample (Table 1) is a cuttings fragment of quartzofeldspathic altered welded tuff from the mafic-poor Ammonia Tanks Tuff comprising a welded tuff aquifer of the Timber Mountain Aquifer (Drellack and Prothro, 1997).

\section{Scanning Electron Microscopy}

SEM evaluation (Table 2) suggests that this sample represents probable vesicle/vug fillings. A rough sample surface (Figure 19) is covered by large blocky, euhedral zeolites crystals (possible chabazite based on morphology and EDS) with finer grained euhedral zeolite crystal aggregates (possible philipsite based on morphology and EDS) intergrown with the larger crystals.

\section{Sample 3300}

\section{$\underline{\text { General Description }}$}

This sample (Table 1) is a sidewall core of quartzofeldspathic altered welded tuff from the mafic-poor Rainier Mesa Tuff comprising a welded tuff aquifer of the Timber Mountain Aquifer (Drellack and Prothro, 1997). This particular sample has one exposed open fracture face, which is the focus of the SEM characterization.

\section{$\underline{\text { Scanning Electron Microscopy }}$}

SEM evaluation (Table 2) shows the fracture surface to be moderately rough. Relief is on the order of $0.5 \mathrm{~mm}$ or more with abundant areas of negative relief that tend to be irregular in outline and roughly equidimensional. The fracture surface is entirely coated by sub-spherical aggregates of euhedral to subhedral quartz crystals (approximately 95 to $97 \%$ ) with lesser Fe-oxides (3 to 5\%) as small irregular grains and dendritic accumulations (Figures 20 and 21).

\section{Drill Hole ER-EC-5}




\section{$\underline{\text { Sample } 1200}$}

\section{General Description}

The sample is a split piece of sidewall core that has been described (Table 1) as a quartzofeldspathic altered tuff from the mafic-rich Ammonia Tanks Tuff comprising a welded tuff aquifer from the Timber Mountain Aquifer (Drellack and Prothro, 1997). This particular sample exhibits intersecting irregular fractures on the split surface which are the focus of the SEM characterization.

\section{$\underline{\text { Scanning Electron Microscopy }}$}

SEM evaluation (Table 2) shows the discontinuous, intersecting irregular fractures to result in sparse areal coverage of the sample surface. As shown in Figure 22, only 2 to $3 \%$ of the sample surface is coated by a layered assemblage of fibrous to acicular Mnoxide (approximately $60 \%$ of the total coverage) with web-like overgrowths of clay minerals (approximately $40 \%$ of the total coverage).

\section{Sample 1440}

\section{General Description}

The sample is a split piece of sidewall core that has been described (Table 1) as a quartzofeldspathic altered tuff from the mafic-rich Ammonia Tanks Tuff comprising a welded tuff aquifer from the Timber Mountain Aquifer (Drellack and Prothro, 1997). This particular sample exhibits an irregular fracture surface, which is the focus of the SEM characterization.

\section{$\underline{\text { Scanning Electron Microscopy }}$}

SEM evaluation (Table 2) shows the fracture surface to be rough and typically granular and to have coarse, blocky offsets in the fracture surface. Local relief is greater than $0.5 \mathrm{~mm}$ with the surface having limited porosity. This porosity occurs largely interstitial to the matrix mineral phases exposed on the surface and is typified by angular voids up to $0.01 \mathrm{~mm}$. Only 2 to $3 \%$ of the fracture surface exhibits secondary mineral phases. In this sample these phases are comprised of barite (1-2\%), possible (based on EDS spectra) cuprotungstite $\left[\mathrm{Cu}_{3}\left(\mathrm{WO}_{4}\right)_{2}(\mathrm{OH})_{2},<1 \%\right]$, and scheelite $\left[\mathrm{CaWO}_{4},<1 \%\right]$. These phases are more typically associated with the formation and weathering of phases formed during hydrothermal processes. As shown in Figure 23, the possible cuprotungstite occurs as an irregular and massive grain, with numerous desiccation cracks, loosely attached to the fracture surface. The eroded scheelite (Figure 24) occurs more intimately intergrown with the rock matrix minerals. This suggests that the scheelite may be an earlier hydrothermal phase and that the cuprotungsite formed in response to supergene processes. Barite occurs as small irregular grains loosely attached to the fracture surface (Figure 24). 


\section{$\underline{\text { Sample 2105 }}$}

\section{General Description}

The sample is a split piece of sidewall core that has been described (Table 1) as a quartzofeldspathic altered tuff from the mafic-rich Ammonia Tanks Tuff comprising a welded tuff aquifer from the Timber Mountain Aquifer (Drellack and Prothro, 1997). This particular sample exhibits a smooth to rough granular fracture surface, which is the focus of the SEM characterization.

\section{$\underline{\text { Scanning Electron Microscopy }}$}

SEM evaluation (Table 2) indicates the fracture surface to be $100 \%$ coated by a finegrained granular mixture of clay, chalcedony, and Fe-oxide. The Fe-oxide occurs as disseminated irregular grains and in discrete, relatively concentrated bands (Figure 25). The sample surface exhibits significant porosity comprised of small, smooth, typically rounded voids up to $0.01 \mathrm{~mm}$ in maximum dimension (Figure 26). The sample coating phases are intimately mixed and are dominated by clays (probable illite and smectite, 5055\%), with lesser chalcedony (30-35\%) and Fe-oxide (15-20\%).

\section{Sample 2135}

\section{General Description}

The sample is a split piece of sidewall core that has been described (Table 1) as a quartzofeldspathic altered tuff from the mafic-rich Ammonia Tanks Tuff comprising a welded tuff aquifer from the Timber Mountain Aquifer (Drellack and Prothro, 1997). This particular sample exhibits an irregular fracture surface with sparsely developed secondary coatings, which is the focus of the SEM characterization.

\section{$\underline{\text { Scanning Electron Microscopy }}$}

SEM evaluation (Table 2) shows the fracture surface to be smooth and granular with $10 \%$ secondary mineral coatings on the primary rock matrix. The fracture surface has low relief and limited porosity. Secondary phases consist of 5\% Fe-oxide as eroded relicts after primary pyrite, $3 \%$ clay (probable smectite) as wavy, web-like coatings, and $2 \%$ chalcedony as irregular aggregates (Figure 27). Coarse-grained eroded calcite contained within the rock matrix is exposed on the fracture surface and exhibits signs that it has been dissolving.

\section{Drill Hole ER-EC-6}

\section{$\underline{\text { Sample } 2415}$}

\section{$\underline{\text { General Description }}$}


This material has been described (Table 1) as a quartzo-feldspathic altered, welded tuff from the Pahute Mesa Lobe of the Topopah Spring Tuff comprising a welded tuff aquifer within the Lower Paintbrush (Drellack and Prothro, 1997). This particular sidewall core sample has one exposed open fracture face, which is the focus of the SEM characterization.

\section{$\underline{\text { Scanning Electron Microscopy }}$}

SEM evaluation (Table 2) shows the fracture to be irregular with a smooth to matted secondary mineral coating covering $100 \%$ of the surface. There is limited evidence of porosity within the fracture coating. Observed void space is limited and reaches a maximum dimension of $0.01 \mathrm{~mm}$. As shown in Figure 28, fracture phase mineralogy consists of $55 \%$ calcite (as massive to polycrystalline masses exhibiting surfaces indicative of dissolution), $40 \%$ illitic clay mixed with lesser smectite and chalcedony (as a typically matted accumulation), and 5\% Fe-oxide as irregular to rounded grains and botryoidal masses.

\section{$\underline{\text { Sample } 2445}$}

\section{$\underline{\text { General Description }}$}

This material has been described (Table 1) as a quartzo-feldspathic altered, welded tuff from the Pahute Mesa Lobe of the Topopah Spring Tuff comprising a welded tuff aquifer within the Lower Paintbrush (Drellack and Prothro, 1997). The sidewall core sample has been split along an existing fracture face, which is the focus of the SEM characterization.

\section{$\underline{\text { Scanning Electron Microscopy }}$}

SEM evaluation (Table 2) shows the fracture surface to be moderately rough and granular with a $40 \%$ coating of secondary mineral phases comprised of quartz (15\%), Fe-oxide (15\%), and clay (10\%). The quartz crystals occur as weakly eroded euhedral crystals, which are typically surrounded by a fine grained porous mixture of spheroidal to botryoidal Fe-oxide with smectite (Figures 29 and 30). Fe-oxide is also present as polyphase pseudomorphs after pyrite in the rock matrix (Figure 31). Porosity of the fracture coating (voids up to $0.01 \mathrm{~mm}$ ) is confined to the Fe-oxide plus smectite mixture, but appears (Figure 30) to potentially be significant.

\section{Sample 3445}

\section{$\underline{\text { General Description }}$}

This material has been described (Table 1) as a quartzo-feldspathic altered, welded tuff from the Pahute Mesa Lobe of the Topopah Spring Tuff comprising a welded tuff aquifer within the Lower Paintbrush (Drellack and Prothro, 1997). The sidewall core sample has been split along an existing fracture face, which is the focus of the SEM characterization. 


\section{$\underline{\text { Scanning Electron Microscopy }}$}

SEM evaluation (Table 2) shows the fracture surface to be rough to smooth and granular. Relief is minimal $(<0.01 \mathrm{~mm})$ with significant surface porosity. This surface porosity consists of voids up to $0.01 \mathrm{~mm}$ which occur interstitial to the mineral phases coating the surface. The fracture surface (Figure 32) is 100 percent coated with secondary phases comprised of $60-65 \%$ Fe-bearing smectite or chlorite, $30-35 \%$ chalcedony, and $2-3 \%$ rare earth element (REE) - bearing carbonate(?). The probable REE-bearing carbonate (Figure 33) occurs as irregular polycrystalline masses overgrown by clay. EDS analysis of the REE-bearing phase (Figure 34) suggests that it is a Ce-rich carbonate.

\section{Drill Hole ER-EC-7}

\section{$\underline{\text { Sample 940-950 }}$}

\section{$\underline{\text { General Description }}$}

This sample (Table 1) is a cuttings fragment of quartzofeldspathic altered lava from the Rhyolite of Beatty Wash lava flow aquifer within the Timber Mountain Aquifer (Drellack and Prothro, 1997).

\section{$\underline{\text { Scanning Electron Microscopy }}$}

SEM evaluation (Table 2) shows the fracture surface coating to be moderately rough and partially coated $(35-45 \%)$ with a granular mixture of secondary mineral phases (Figure 35). The secondary phases are dominated by 25 to $30 \%$ Ba-bearing Mn-oxide (Hollandite?) which occurs in a variety of morphologies ranging from fibrous to mat-like to spheroidal. Solution etched prismatic quartz crystals are present on 10 to $15 \%$ of the fracture surface. Other secondary phases include: $2 \%$ chalcedony as fine irregular to blocky grains; trace amounts of fine-grained calcite which exhibits solution features; and, trace amounts of dendritic to botryoidal Fe-oxide. Surface relief is minimal (less than $0.01 \mathrm{~mm}$ ). Fracture coating porosity appears to be moderate with observed void spaces ranging up to $0.025 \mathrm{~mm}$.

\section{Drill Hole ER-18-2}

\section{Sample 1940-1950}

\section{General Description}

This material is described (Table 1) as quartzofeldspathic altered welded tuff from the mafic-rich Ammonia Tanks Tuff comprising a welded tuff aquifer within the Timber Mountain Aquifer (Drellack and Prothro, 1997). Thin, discontinuous coatings are present on this sample collected from drill cuttings. 


\section{$\underline{\text { Scanning Electron Microscopy }}$}

SEM evaluation (Table 2) shows the fracture surface coating to be granular to smooth and matted with local, blocky offsets. Surface relief is minimal (on the order of $0.01 \mathrm{~mm}$ ). Surface porosity also appears to be minor, observed voids on the fracture surface are sparse and are typically less than $0.01 \mathrm{~mm}$ across. Fifty to sixty percent of the fracture surface is coated. This coating is dominated by 35-40\% clay (smectite) which occurs as a wavy, web-like mat on the sample surface (Figure 36). Very fine grained $(0.002 \mathrm{~m})$ Fe-oxide occurs as irregular to spheroidal and botryoidal aggregates on 15$20 \%$ of the fracture surface.

\section{$\underline{\text { Sample 1970-1980 }}$}

\section{General Description}

This material is described (Table 1) as quartzofeldspathic altered welded tuff from the mafic-rich Ammonia Tanks Tuff comprising a welded tuff aquifer within the Timber Mountain Aquifer (Drellack and Prothro, 1997). Thin, discontinuous coatings over what appears to be a hydrothermal vein assemblage are present on this sample collected from drill cuttings.

\section{$\underline{\text { Scanning Electron Microscopy }}$}

SEM evaluation (Table 2) shows the fracture surface coating to be moderately rough and granular with blocky offsets. Surface relief is minimal (on the order of $0.02 \mathrm{~mm}$ ) and surface porosity appears to be considerable. Observed voids are relatively abundant but are typically less than $0.01 \mathrm{~mm}$ in dimension. The entire fracture surface (Figure 37 ) is coated with solution-pitted, Mn-bearing calcite (40-50\%), a matted mixture of illite/smectite (30-45\%), and fibrous to prismatic Ba-bearing Mn-oxide (Hollandite?, 15$20 \%)$.

\section{Sample 2050-2060}

\section{$\underline{\text { General Description }}$}

This material is described (Table 1) as quartzofeldspathic altered welded tuff from the mafic-rich Ammonia Tanks Tuff comprising a welded tuff aquifer within the Timber Mountain Aquifer (Drellack and Prothro, 1997). Secondary coatings are present on this sample collected from drill cuttings.

\section{$\underline{\text { Scanning Electron Microscopy }}$}

SEM evaluation (Table 2) indicates that this fracture surface is moderately smooth and matted to fine-grained and granular. Surface relief is minimal (on the order of $0.02 \mathrm{~mm}$ ). Surface coating porosity is suggested to be significant based on the presence of what are 
interpreted to be desiccation cracks that are likely to have been caused by the dehydration of smectite clays. Specific observed voids are minimal and less than $0.01 \mathrm{~mm}$ in dimension. Secondary phases cover approximately $75 \%$ of the fracture surface and consist of 50\% smectite (probably mixed with chalcedony), 10\% blocky chalcedony, 10$15 \% \mathrm{Fe}$-oxide as irregular aggregates, and trace amounts of Ba-bearing Mn-oxide (Hollandite?) as roughly radial aggregates of fibrous to prismatic crystals. Figure 38 shows a desiccation crack transecting the fracture coating material, which is dominated by smectite clay with minor overgrowths of chalcedony and Mn-oxide.

\section{Drill Hole UE-29a\#2}

\section{Sample 167.2-167.3}

\section{General Description}

This material is described (Table 1) as the Rhyolite of Vent Pass (Warren written communication, 2000). It is uncertain what the hydrogeologic classification or significance of this interval is at this time. Given the shallow depth to water in Fortymile Wash and evidence for significant local recharge (Thomas et al, 1999), this warrants revisiting. Multiple irregular and discontinuous fractures are present in this sample of diamond drill core.

\section{Scanning Electron Microscopy}

SEM evaluation (Table 2) of this sample was complicated by poor grounding of the porous sample resulting in severe charging of the sample surface and poor resolution by the SEM. It is not clear, based on the currently available results, what the typical fracture surface texture, mineralogy, or extent of fracture coating development is. Limited observations indicate that the sample surface is at least locally coated by irregular elemental copper grains and spheres to spheroidal aggregates of $\mathrm{Zn}$-oxide or silicate in an opaline silica matrix. These phases are indicated by numbers 1,2 , and 3 , respectively, marked on Figure 39.

\section{Sample 812.1-812.2}

\section{General Description}

This material is described (Table 1) as the mafic-rich Calico Hills Tuff (Warren written communication, 2000). It is uncertain what the hydrogeologic classification or significance of this interval is at this time. Given the shallow depth to water in Fortymile Wash and evidence for significant local recharge (Thomas et al, 1999), this warrants revisiting. A single prominent fracture is present in this sample of diamond drill core.

\section{$\underline{\text { Scanning Electron Microscopy }}$}


SEM evaluation (Table 2) shows the fracture surface coating to be typically smooth with a matted or veiled coating developed upon an underlying granular surface. Relief on the fracture surface is approximately $0.05 \mathrm{~mm}$. Observable pores in the fracture coating materials are uncommon and reach a maximum dimension of $0.01 \mathrm{~mm}$. The entire fracture surface is coated by secondary mineral phases which consist of chalcedony (50\%, typically as fine crystals comprising a fine-grained mat with local coarse blocky crystals), Fe-oxide (20\% as as irregular to spheroidal/botryoidal masses), and clay (30\% as probable smectite). A typical view of the fracture surface (showing Fe-oxide overlying the chalcedony mat) is shown in Figure 40. Trace amounts of coarser grained and discrete Fe-oxides were observed and are distinctly Pb-bearing based on EDS analysis.

\section{Sample 817.8-817.9}

\section{General Description}

This material is described (Table 1) as the mafic-rich Calico Hills Tuff (Warren written communication, 2000). It is uncertain what the hydrogeologic classification or significance of this interval is at this time. Given the shallow depth to water in Fortymile Wash and evidence for significant local recharge (Thomas et al, 1999), this warrants revisiting. A rough irregular surface with numerous offsets, suggestive of multiple intersecting fractures, is present on this sample of diamond drill core.

\section{$\underline{\text { Scanning Electron Microscopy }}$}

SEM evaluation (Table 2) indicates that the sample surface is smooth to slightly granular and entirely coated by a mat-like mixture comprised of chalcedony plus illite/smectite clay (50-55\%), with Mn-oxides (35\%), and Fe-oxides (10-15\%). The observed Mn-oxide occurs in two distinct morphologies with apparent compositional differences. A blocky variety of $\mathrm{Mn}$-oxide is low in $\mathrm{Fe}$ and high in $\mathrm{Al}$, while a fibrous to acicular variety is relatively high in $\mathrm{Fe}$ (and $\mathrm{Si}$ and $\mathrm{Pb}$ ) and low in $\mathrm{Al}$ (based on EDS analyses). The sample surface exhibits low relief (on the order of $0.05 \mathrm{~mm}$ ) and limited evidence for coating porosity. Observed surface voids have measurable maximum dimension less than 0.01 $\mathrm{mm}$. There is evidence for the development of secondary fracture coating porosity. The presence of desiccation cracks in the sample surface (Figure 41) is likely to be a post sampling effect induced by sample drying. Features such as this may expose a reactive or porous mineral surface in cores subject to experiments that would not be present on natural fractures in place in the groundwater system.

\section{Drill Hole ER-OV-3c}

\section{Sample 510-540}

\section{$\underline{\text { General Description }}$}


This material is described (Table 1) as welded tuff from the Ammonia Tanks Tuff comprising a welded tuff aquifer within the Timber Mountain Aquifer (Robledo et al, 1998). An irregular fracture surface is present in the cuttings fragment observed.

\section{Scanning Electron Microscopy}

SEM evaluation (Table 2) shows the fracture surface to be rough and irregular. Surface relief is on the order of $0.05 \mathrm{~mm}$ with local microfractures and areas of negative relief that are of variable morphology. The dimensions of these depressions are variable but commonly on the order of $0.05 \mathrm{~mm}$. Surface porosity is largely inhibited by what appears to be a fairly tight mat-like covering dominated by chalcedony. However locally pervasive microfractures may present suitable conduits for fluid movement into the rock matrix. The fracture surface is entirely covered by $35 \%$ chalcedony, $35 \%$ clay (smectite?, typically intermixed with chalcedony), and 30\% Fe-oxide. The Fe-oxide occurs in 2 distinct morphologies. Spherical rosettes (hematite?) are locally exposed beneath the chalcedony mat (Figure 42). A more common form of Fe-oxide in this sample is represented by highly porous and lacy Fe-oxide exposed in association with the mat-like surface covering (Figure 43).

\section{Drill ER-OV-3c2}

\section{$\underline{\text { Sample 270-320 }}$}

\section{$\underline{\text { General Description }}$}

This material is described (Table 1) as welded tuff from the Ammonia Tanks Tuff comprising a welded tuff aquifer within the Timber Mountain Aquifer (Robledo et al, 1998). An irregular fracture surface is present in the cuttings fragment observed.

\section{Scanning Electron Microscopy}

SEM evaluation (Table 2) shows this sample to have an irregular fracture surface dominated by a mat-like covering of chalcedony and clay minerals. Where the mat is not present both Fe-oxide and Mn-oxide phases are visible (Figure 44). This suggests that the oxide phases either predate the development for the mat-like covering of chalcedony plus clay or that the fracture coating materials are actually a three-dimensional honeycomb-like feature. It is not certain, based on the limited sample size which is more likely. The sample does present a significant degree of surface relief and porosity in addition to an abundance of reactive secondary phases. The surface is covered by 30$40 \%$ chalcedony, $30-40 \%$ clay minerals, $18-20 \%$ irregular Fe-oxide, and $5-7 \%$ prismatic Mn-oxide.

\section{Drill ER-OV-6a}

\section{$\underline{\text { Sample 44-65 }}$}




\section{$\underline{\text { General Description }}$}

This material is described (Table 1) as rhyolitic lava of Colson Pond (Robledo et al, 1998). This sample is likely to represent a local lava flow aquifer high in the volcanic sequence beneath the alluvium in Oasis Valley. Poorly developed fracture coatings are observed in this sample of drill cuttings.

\section{$\underline{\text { Scanning Electron Microscopy }}$}

SEM evaluation (Table 2) shows the fracture surface coating to have a rough blocky surface with relief greater than $0.05 \mathrm{~mm}$. The surface is comprised predominantly of large fractured euhedral quartz crystals with two generations of euhedral potassic feldspar. Secondary coatings consist of $20 \%$ surface area coverage comprised of chalcedonic silica which occurs as dense polycrystalline masses on the surface of other phases. The secondary silica also occurs partially healing the fractures observed in the coarse grained quartz crystals (Figure 45). 


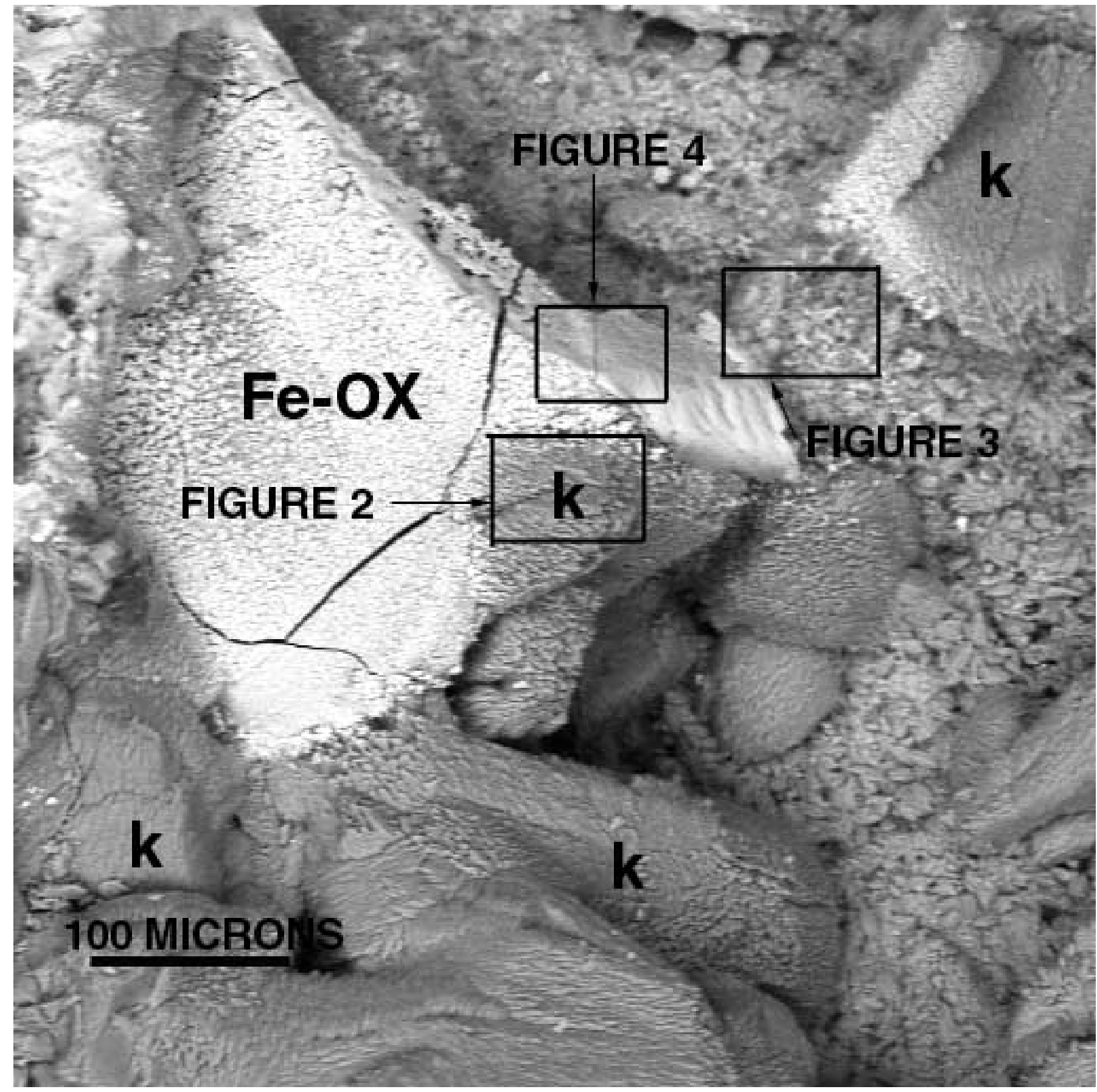

Figure 1. ER-EC-1, 2480-2490 feet, Back scattered electron image showing eroded feldspar (?) crystals (k) as shown in the inset labeled Figure 2; with fine-grained interstitial accumulation of chalcedony, Mn-oxides, and clay minerals as shown in the inset labeled Figure 3; and a fractured, partially supported layer of massive to botryoidal Fe-oxides (Fe-OX) as shown in the inset labeled Figure 4. 


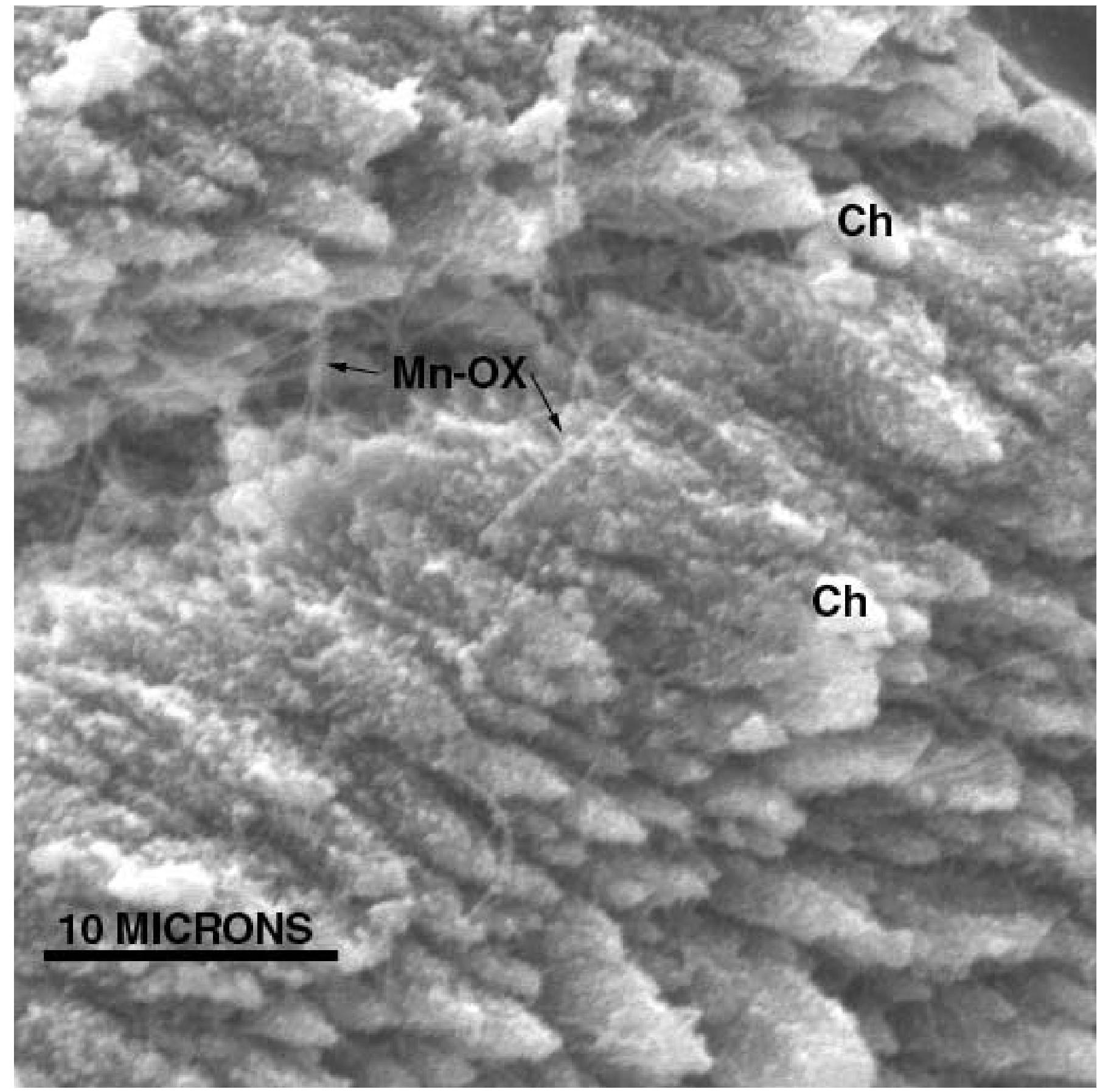

Figure 2. ER-EC-1, 2480-2490 feet, Secondary electron image showing inset from Figure 1. Highly eroded feldspar (?) crystals with minor overgrowths of irregular to blocky chalcedony (Ch) and acicular/fibrous $\mathrm{Mn}-\mathrm{Oxide}(\mathrm{Mn}-\mathrm{OX})$. 


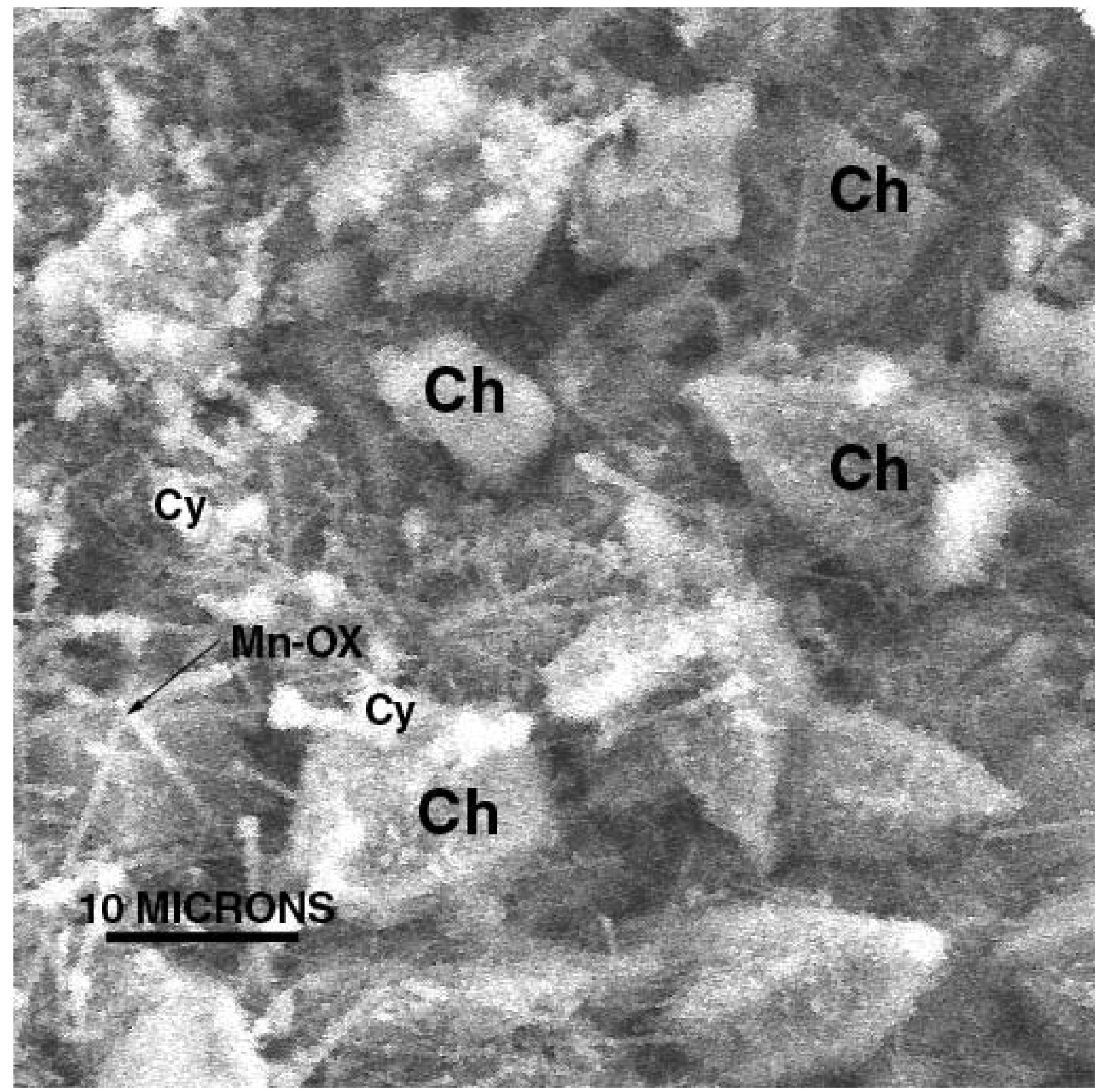

Figure 3. ER-EC-1, 2480-2490 feet, Secondary electron image showing inset from Figure 1. Fine grained accumulation of chalcedony (Ch), Mn-oxide (Mn-OX), and clay minerals (Cy) interstitial to eroded blocky feldspar (?) crystals. 


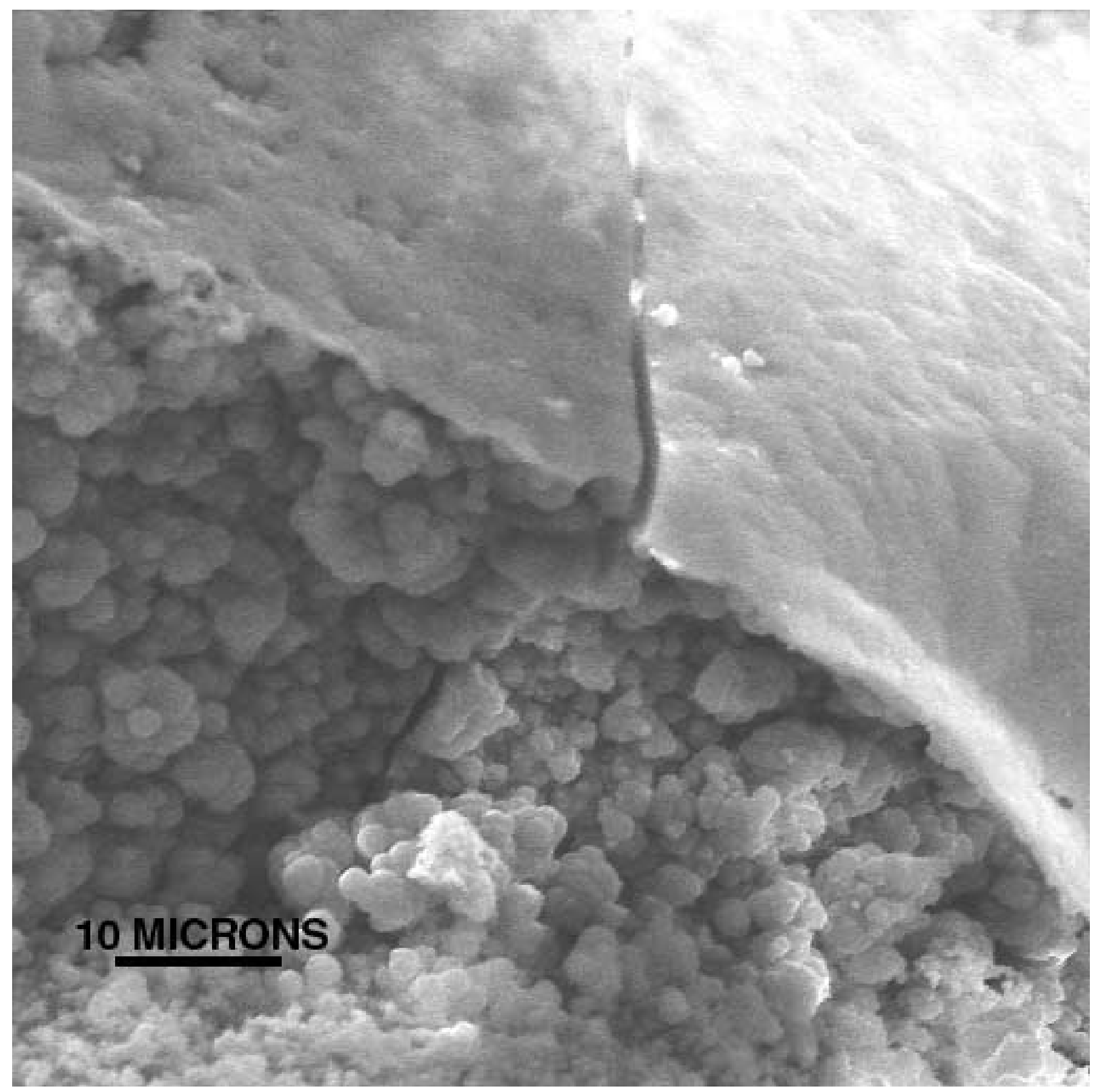

Figure 4. ER-EC-1, 2480-2490 feet, Back scattered electron image showing inset from Figure 1. Fracture through $\mathrm{Fe}$-oxide showing botryoidal surface and more massive interior of the layer. As shown in Figure 1, this Fe-oxide layer is only partially supported by the subjacent fracture surface and has broken away exposing the underlying fine grained accumulation of mixed chalcedony, Mn-oxide, and clay. 


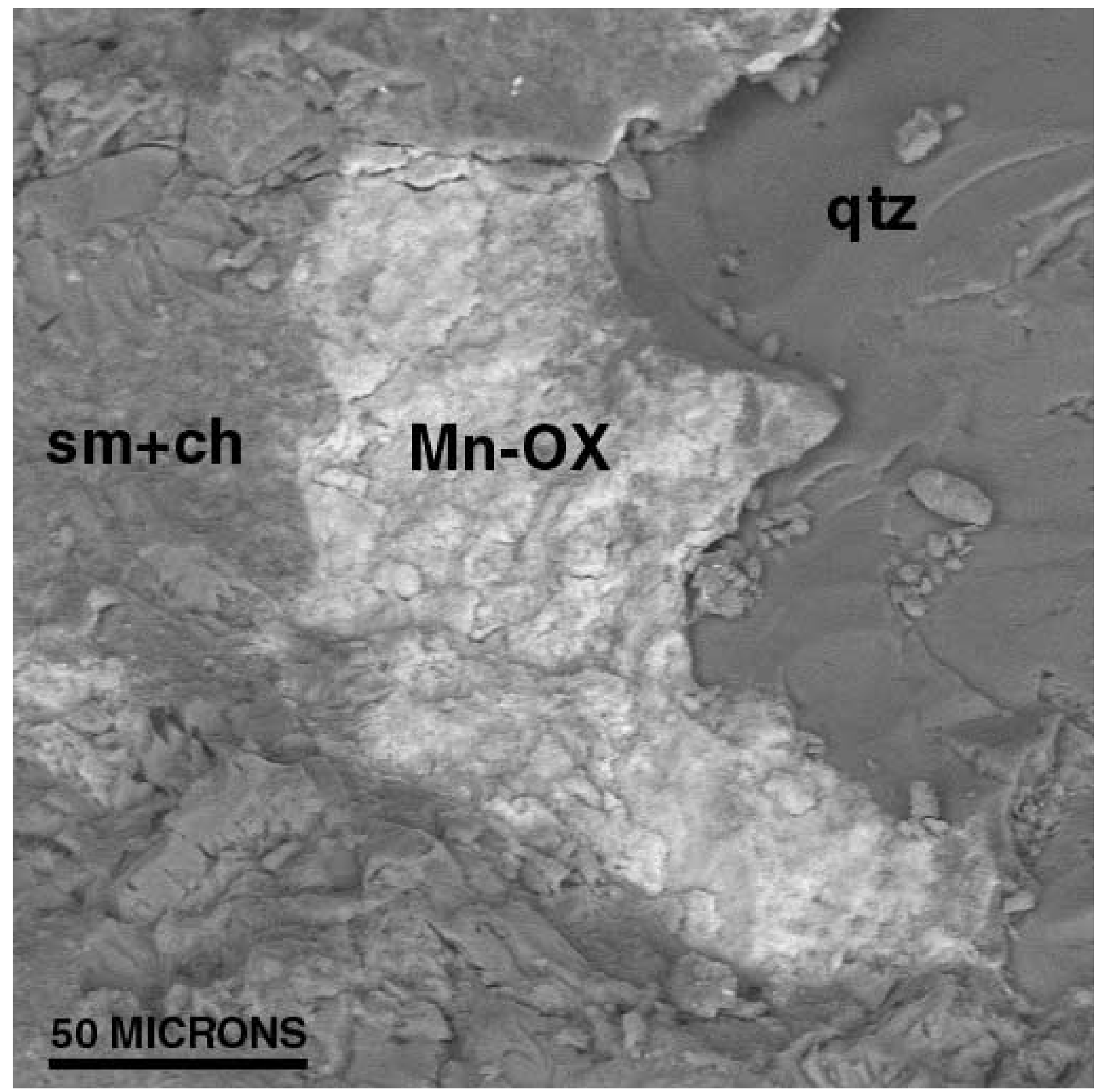

Figure 5. ER-EC-1, 2800-2810 feet, Back scattered electron image showing thin, massive, polycrystaline accumulation of $\mathrm{Mn}$-oxide (Mn-OX) with mixed smectite plus chalcedony $(\mathrm{sm}+\mathrm{ch})$ adjacent to a quartz phenocryst (qtz). 


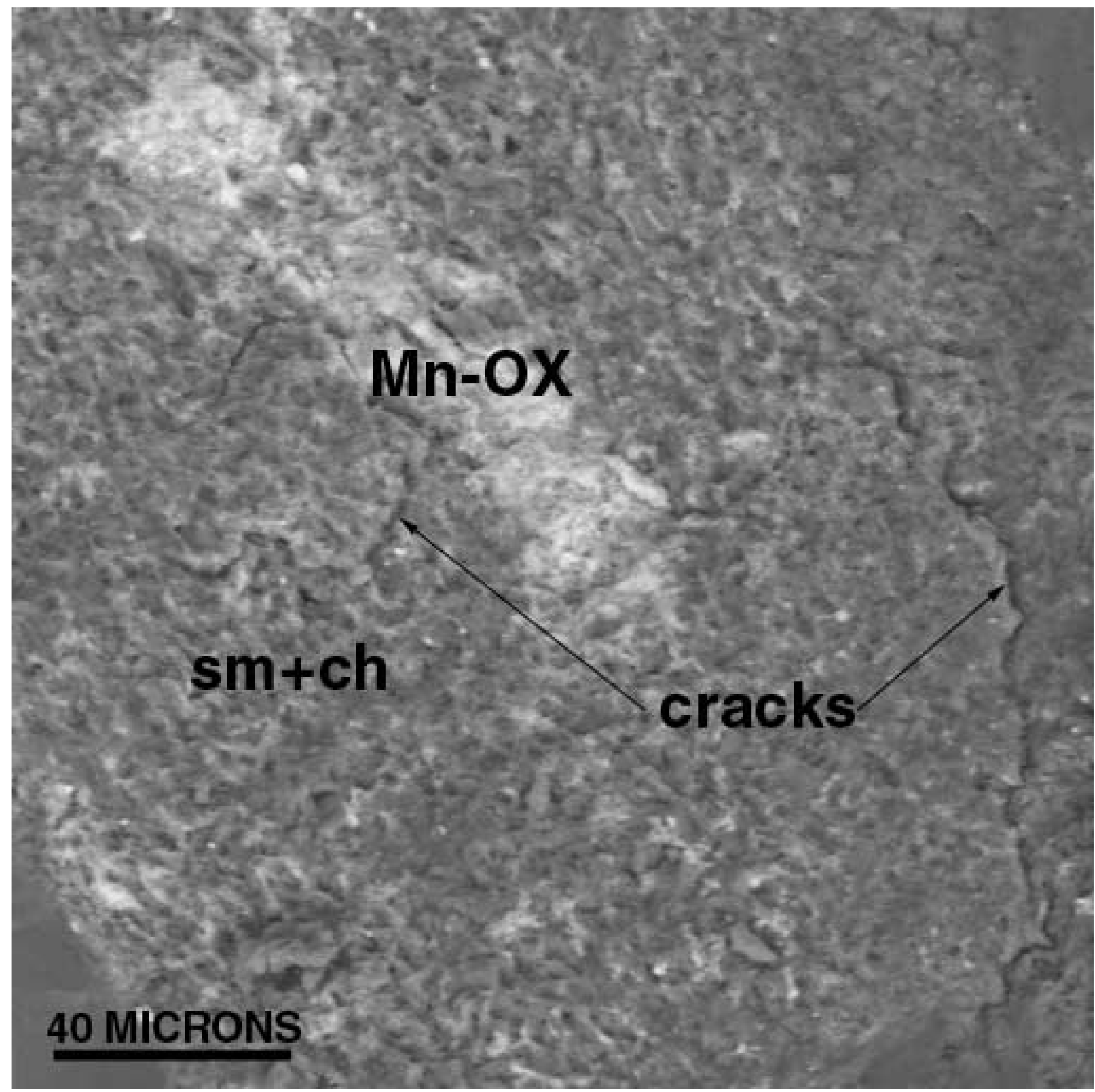

Figure 6. ER-EC-1, 2800-2810 feet, Back scattered electron image showing what appears to be a relatively porous mixture of smectite and chalcedony (sm+ch) with $\mathrm{Mn}$-oxides (Mn-OX). Note the presence of cracks in the smectite-rich portion of the fracture coating. These are suggestive of dessication. 


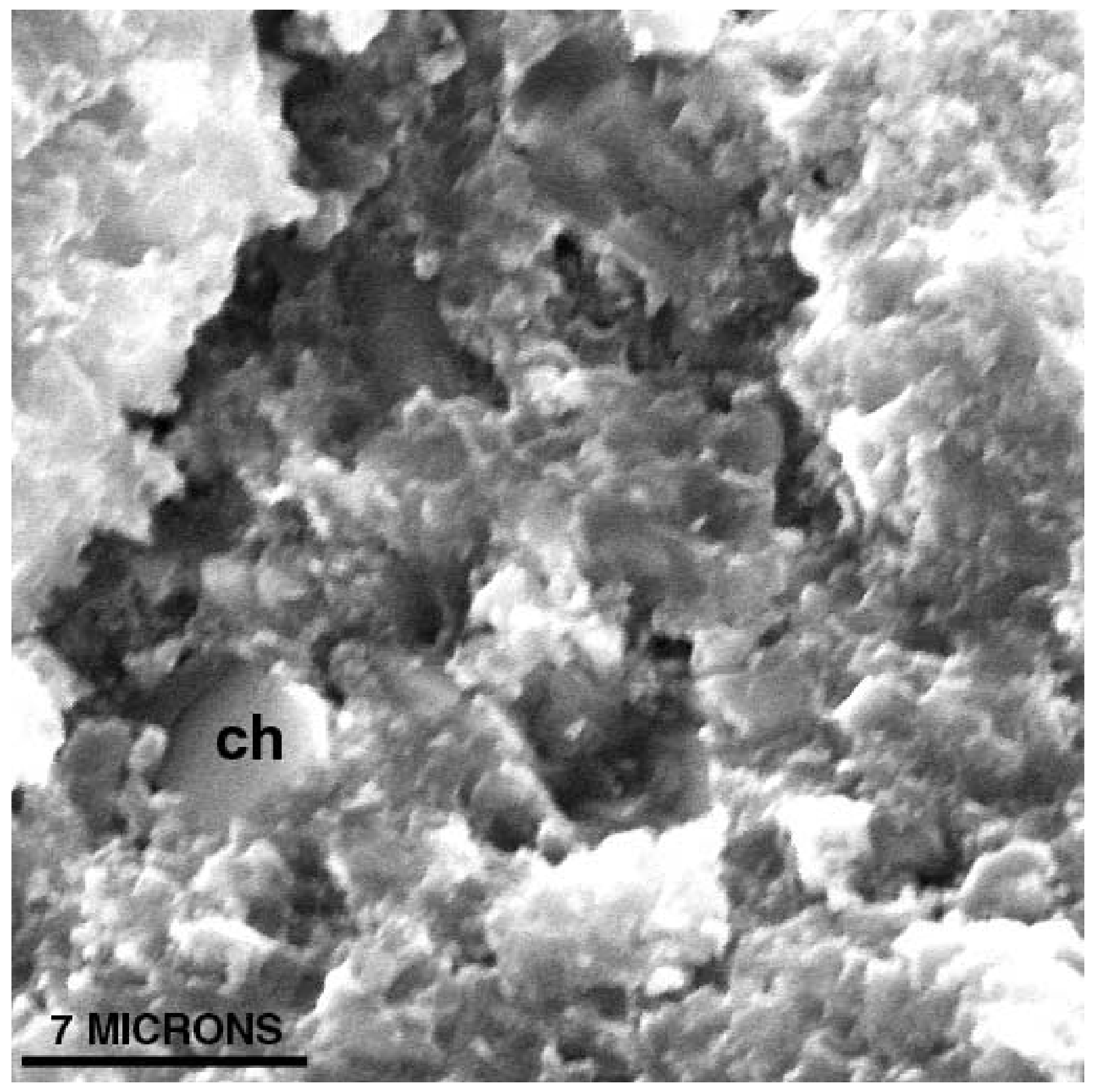

Figure 7. ER-EC-1, 2800-2810 feet, Secondary electron image showing the fine-grained smectite coating. A blocky chalcedony (ch) crystal is present in the lower left field of view. 


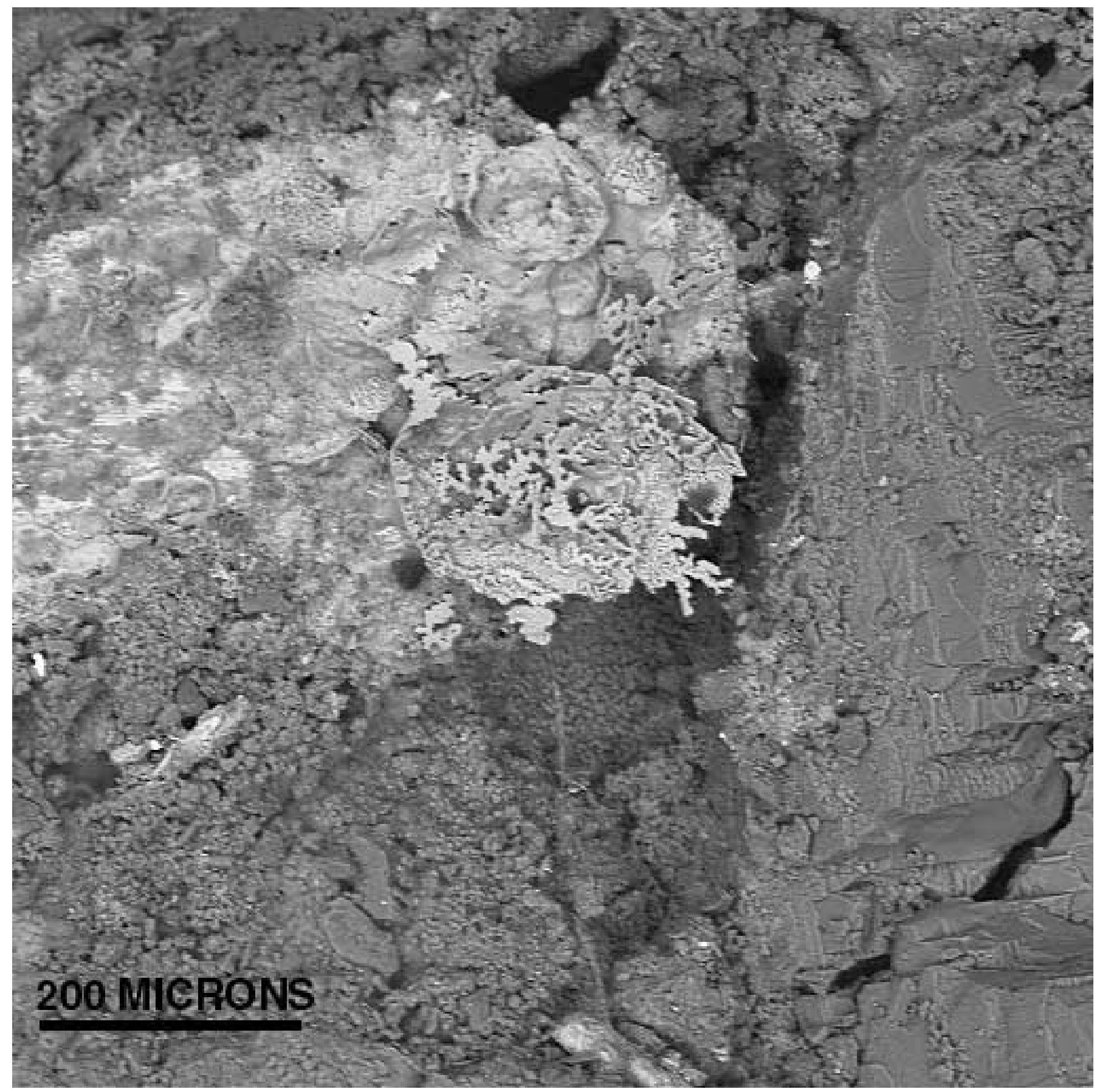

Figure 8. ER-EC-1, 4530 feet, Back scattered electron image showing botryoidal to massive accumulation of Fe-oxide (Fe-OX) in fracture largely filled with probable smectite. 


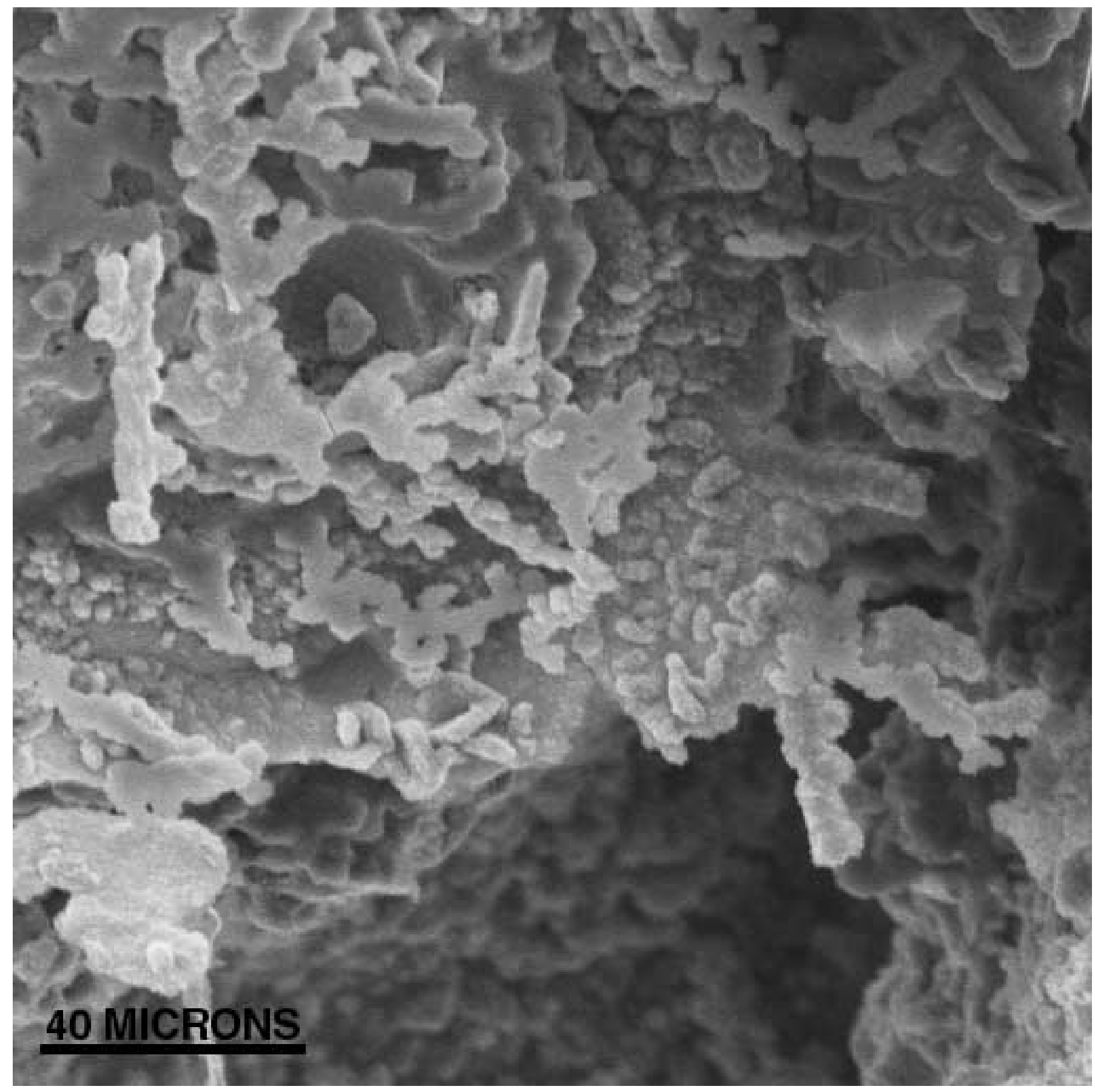

Figure 9. ER-EC-1, 4530 feet, Secondary electron image showing close-up view of Fe-oxide shown in Figure 8. 


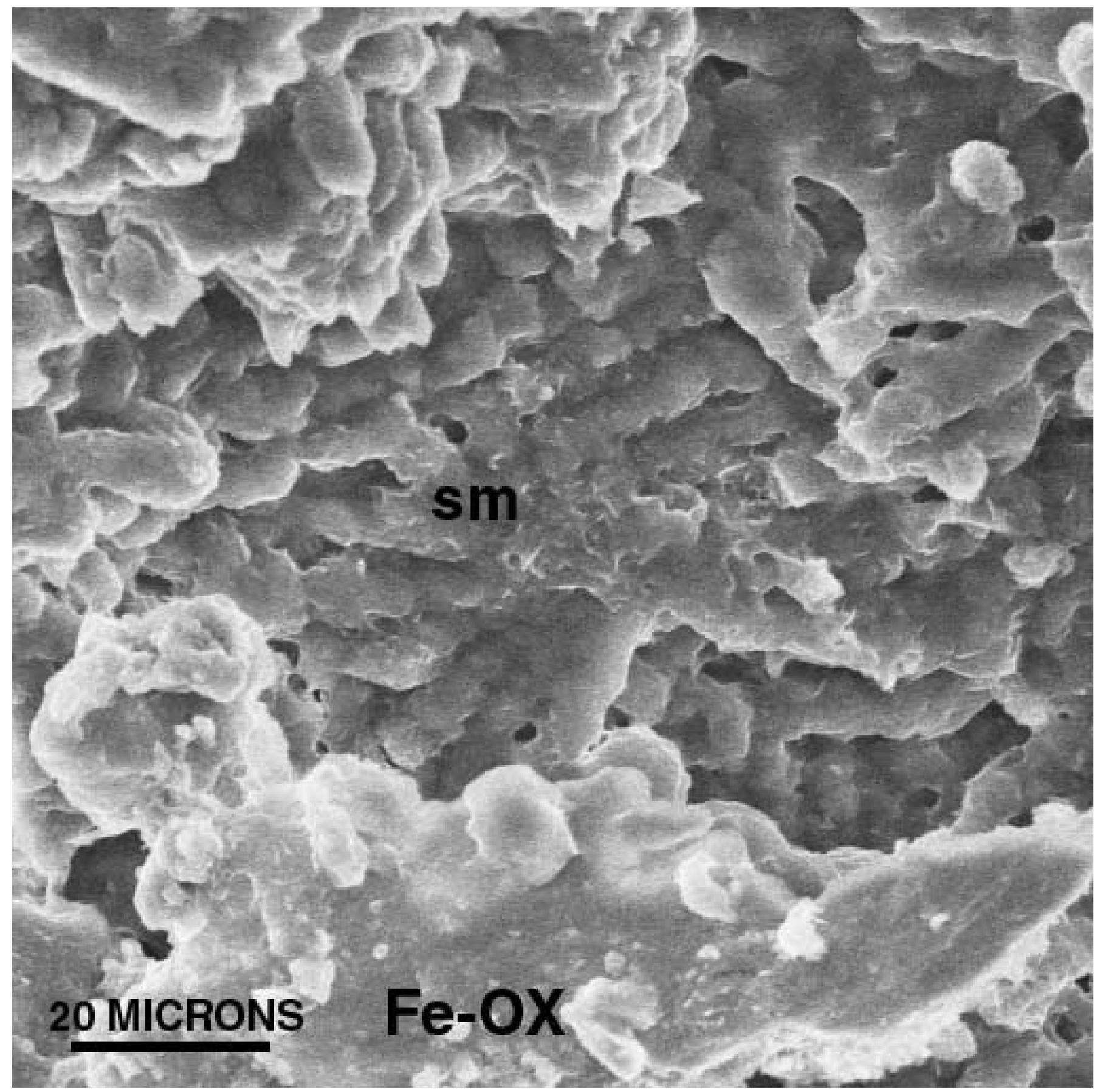

Figure 10. ER-EC-1, 4530 feet, Secondary electron image showing wavy, web-like accumulation of probable smectite (sm) subjacent to Fe-oxide (Fe-OX). 


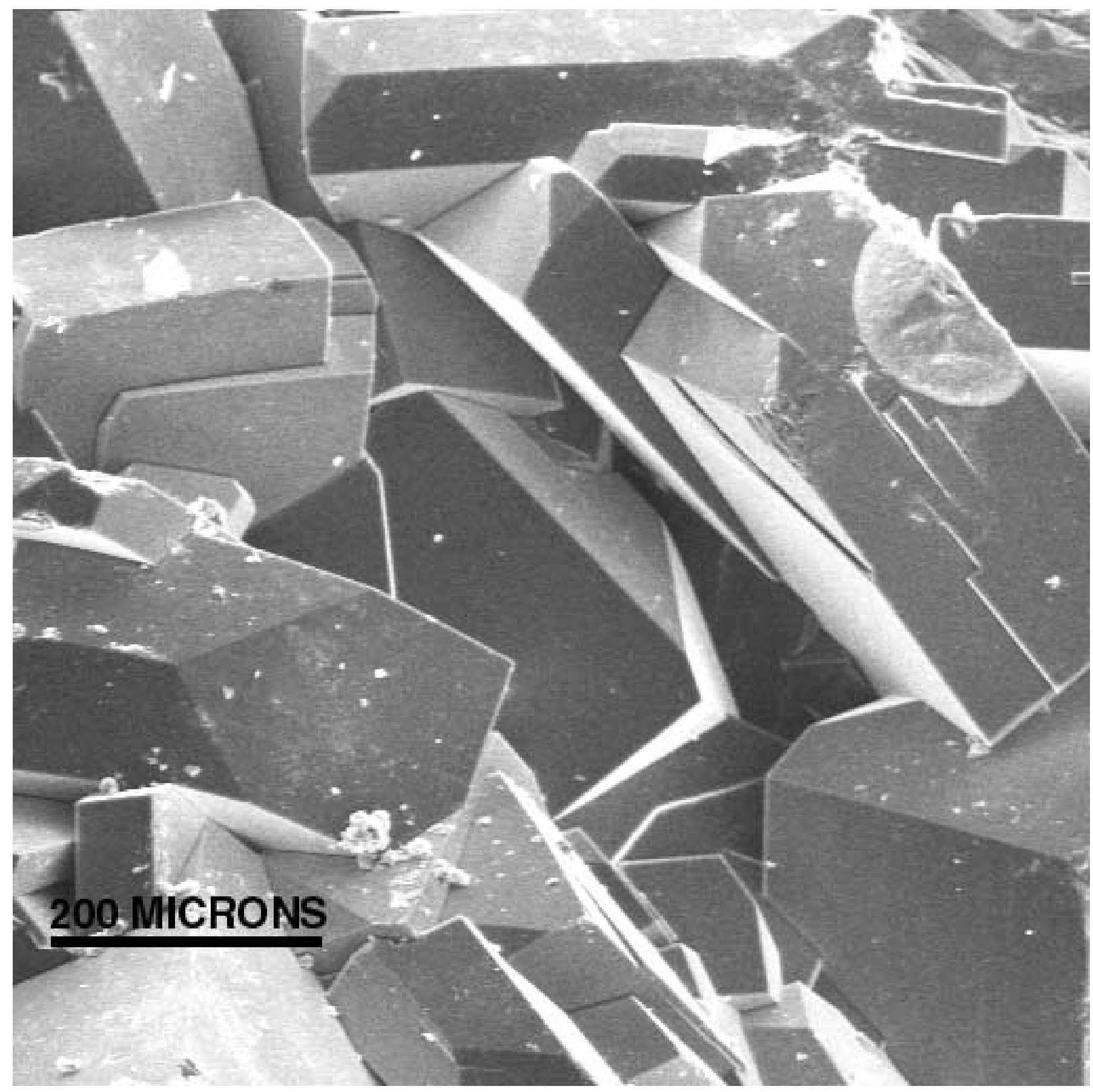

Figure 11. ER-EC-4, 1910-1920 feet, Secondary electron image showing euhedral zeolite (heulandite?) as fracture/vug lining. 


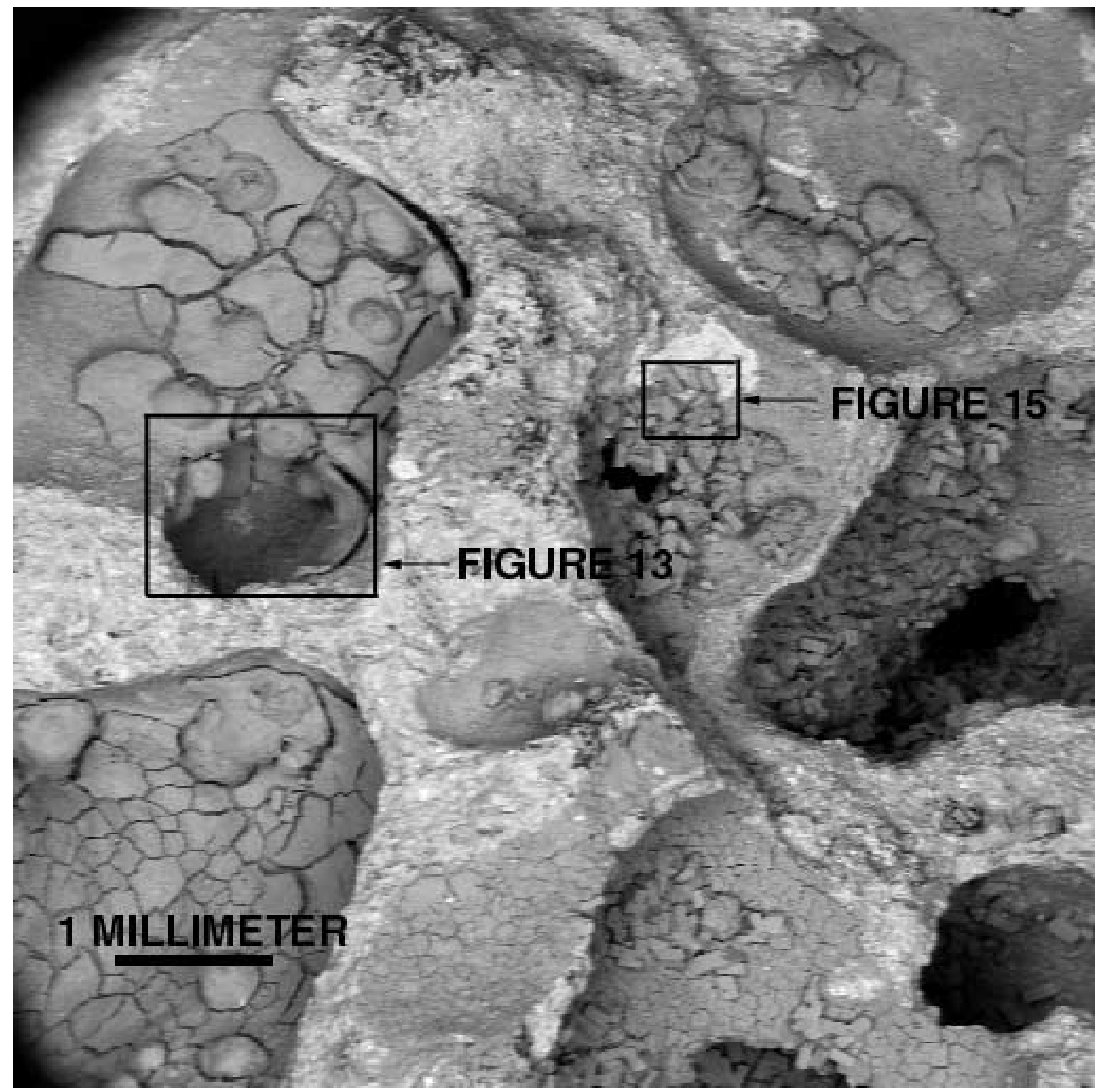

Figure 12. ER-EC-4, 2030-2040 feet, Back scattered electron image overview of sample surface showing vesicle/vug linings. Note abundant apparent desication cracks in vesicle linings and insets showing locations of Figures 13 and 15. 


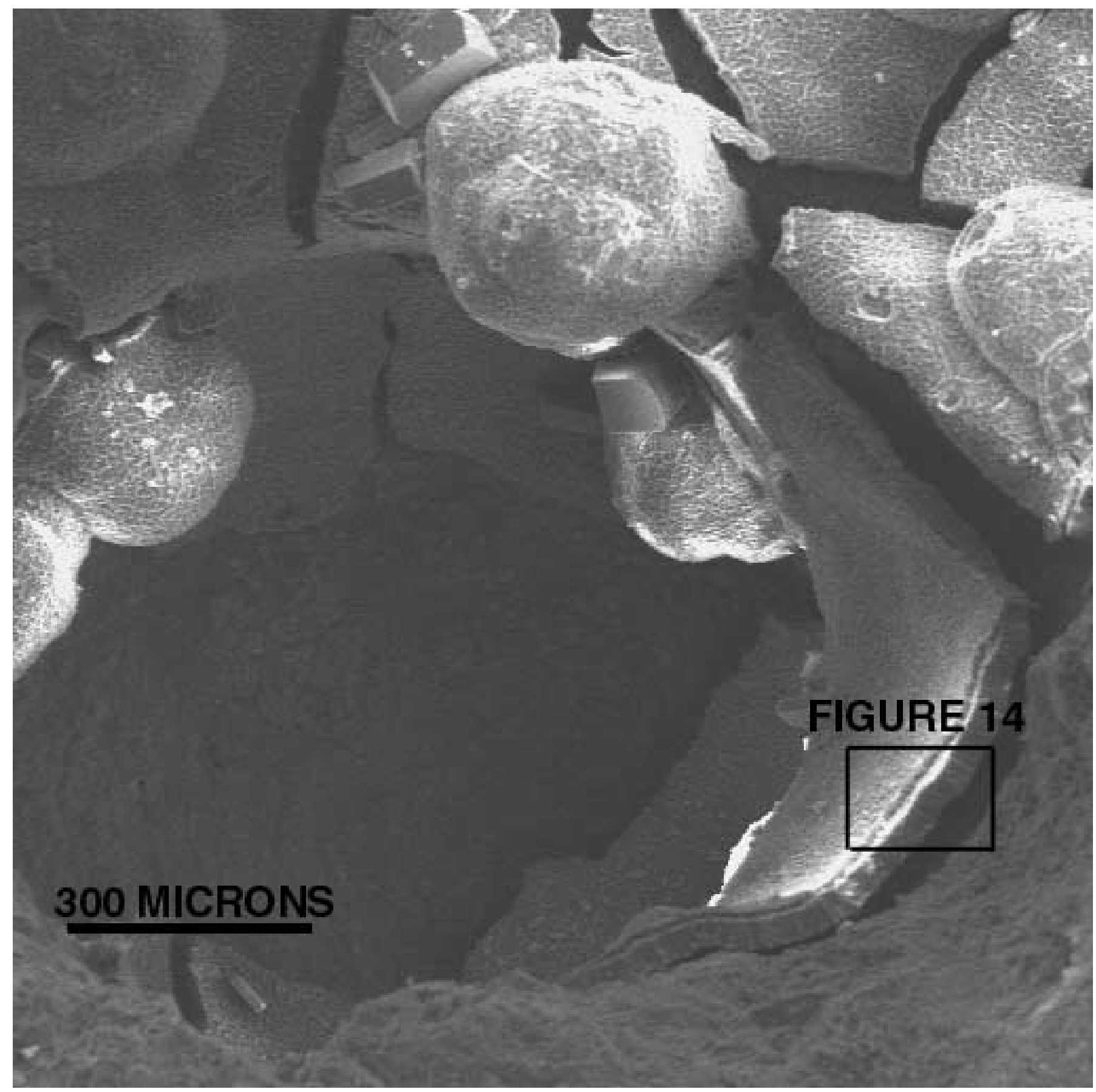

Figure 13. ER-EC-4, 2030-2040 feet, Secondary electron image showing close-up view of vesicle lining shown in Figure 12. Eroded vesicle lining material is comprised predominantly of multiple layers of dolomite (as shown in Figure 14). Euhedral zeolite (clinoptilolite?) crystals are sparsely distributed on sample surface. 


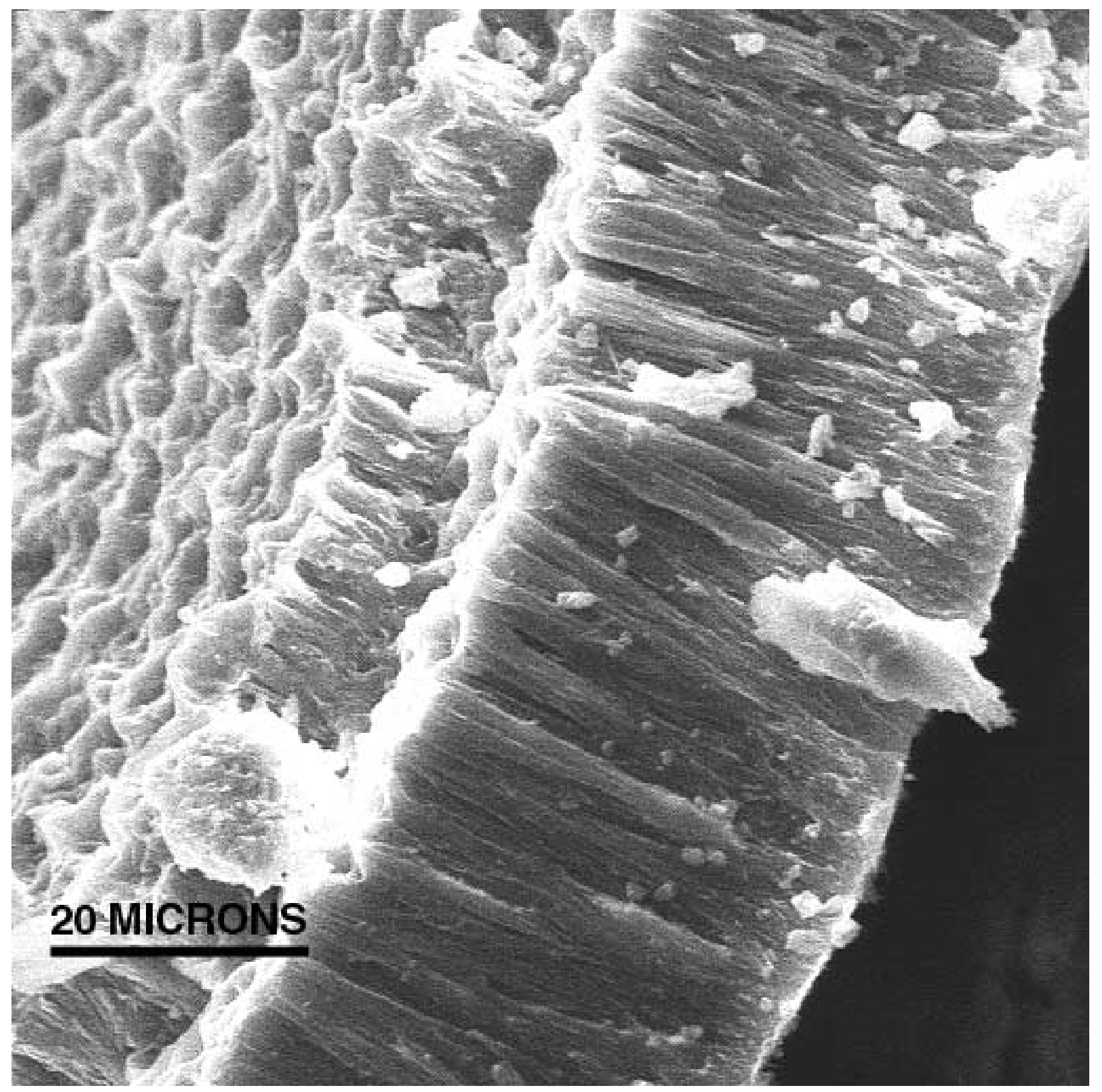

Figure 14. ER-EC-4, 2030-2040 feet, Secondary electron image showing close-up of multiple layers of vesicle lining dolomite as shown in Figures 12 and 13. Note that both layers exhibit evidence of disolution. 


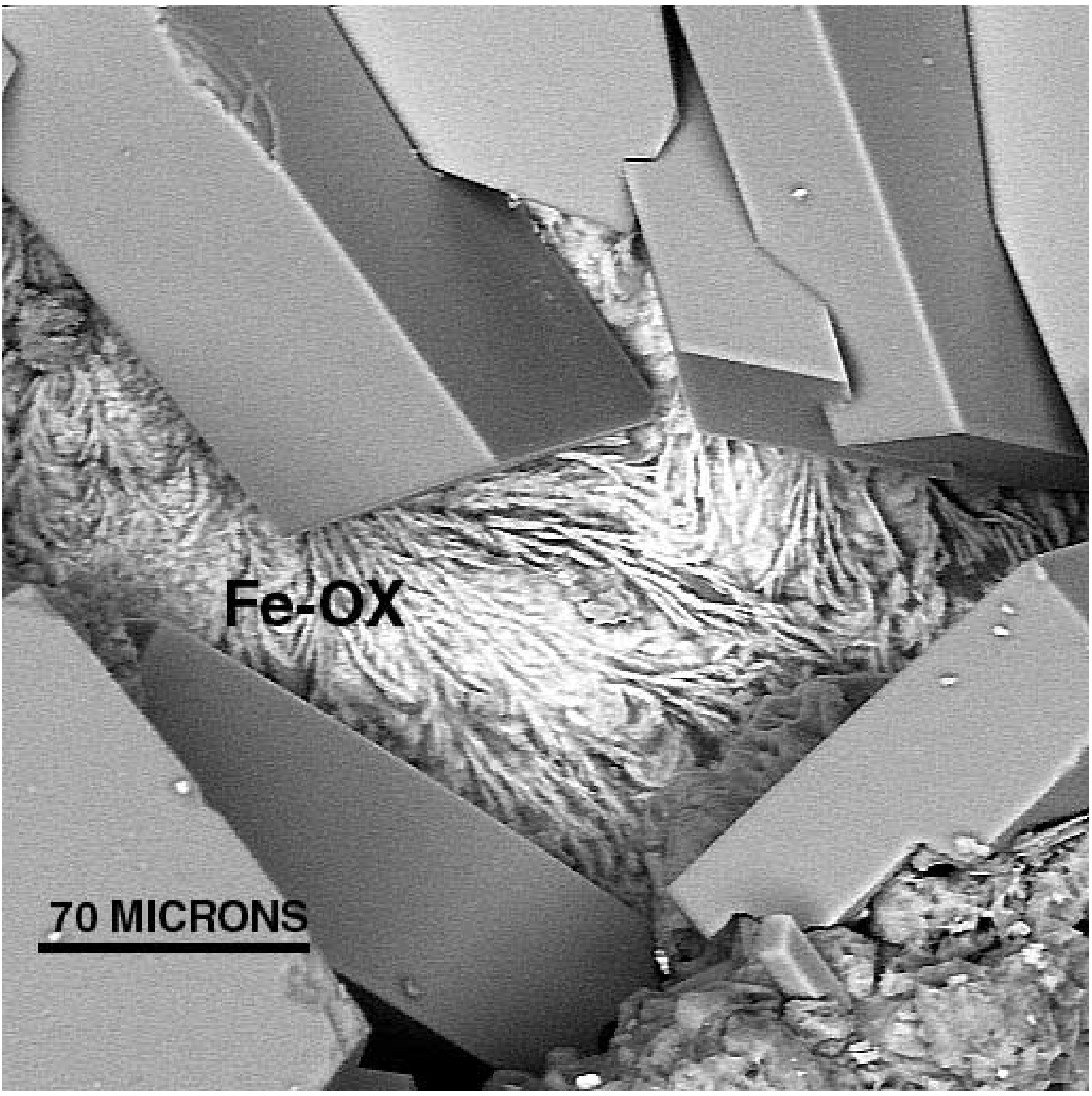

Figure 15. ER-EC-4, 2030-2040 feet, Back scattered electron image showing accumulation of dendritic Fe-oxide (Fe-OX) with overlying euhedral zeolite crystals. 


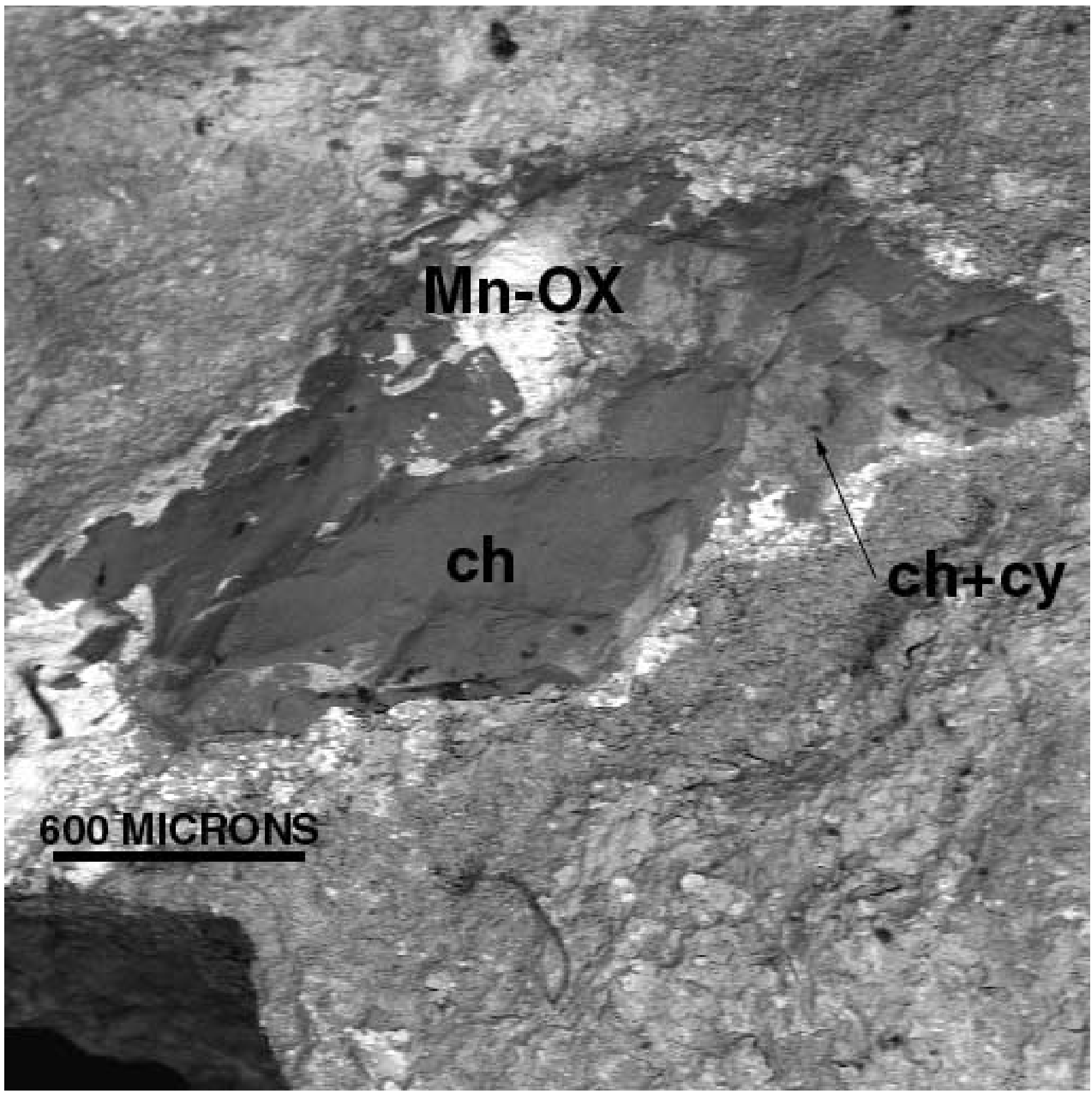

Figure 16. ER-EC-4, 2110-2120 feet, Back scattered electron image showing accumulation of massive chalcedonic silica (ch) and chalcedony mixed with clay (ch+cy) overlying Mn-oxide (Mn-OX). Limited distribution and typically massive texture of fracture coating phases suggests that these materials originally comprised a filled fracture. 


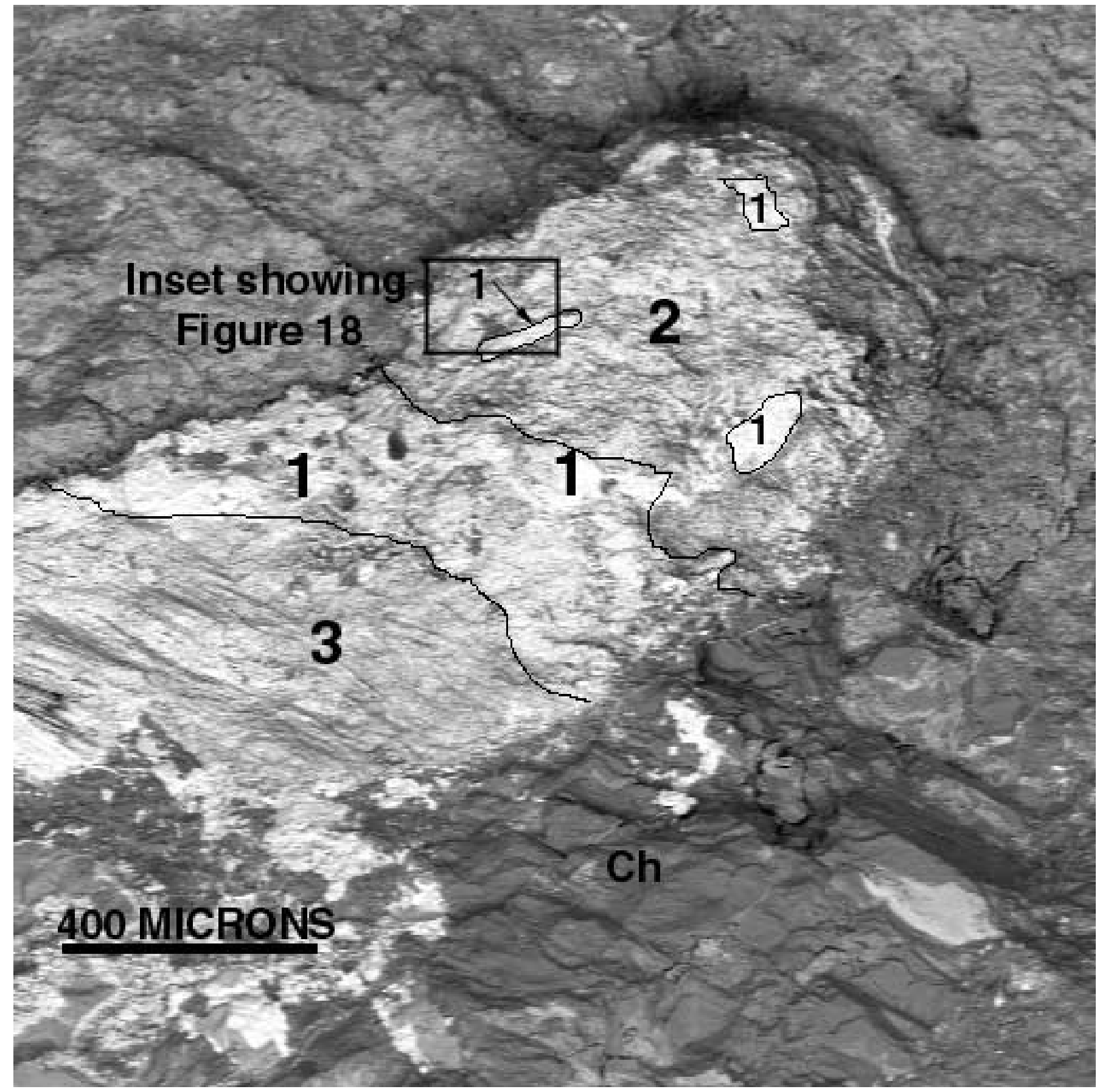

Figure 17. ER-EC-4, 2110-2120 feet. Back scattered electron image showing mixed oxide phase adjacent to chalcedony (ch) on fracture surface. Areas labeled "1" are Ba-bearing Mn-oxide, areas labeled "2" are predominantly Ba-bearing $\mathrm{Mn}$-oxide intermixed with Fe-oxide, chalcedony, and smectite, areas labeled " 3 " are predominantly Fe-oxide intermixed with Ba-bearing Mn-oxide and chalcedony. Inset shows location of Figure 18. 


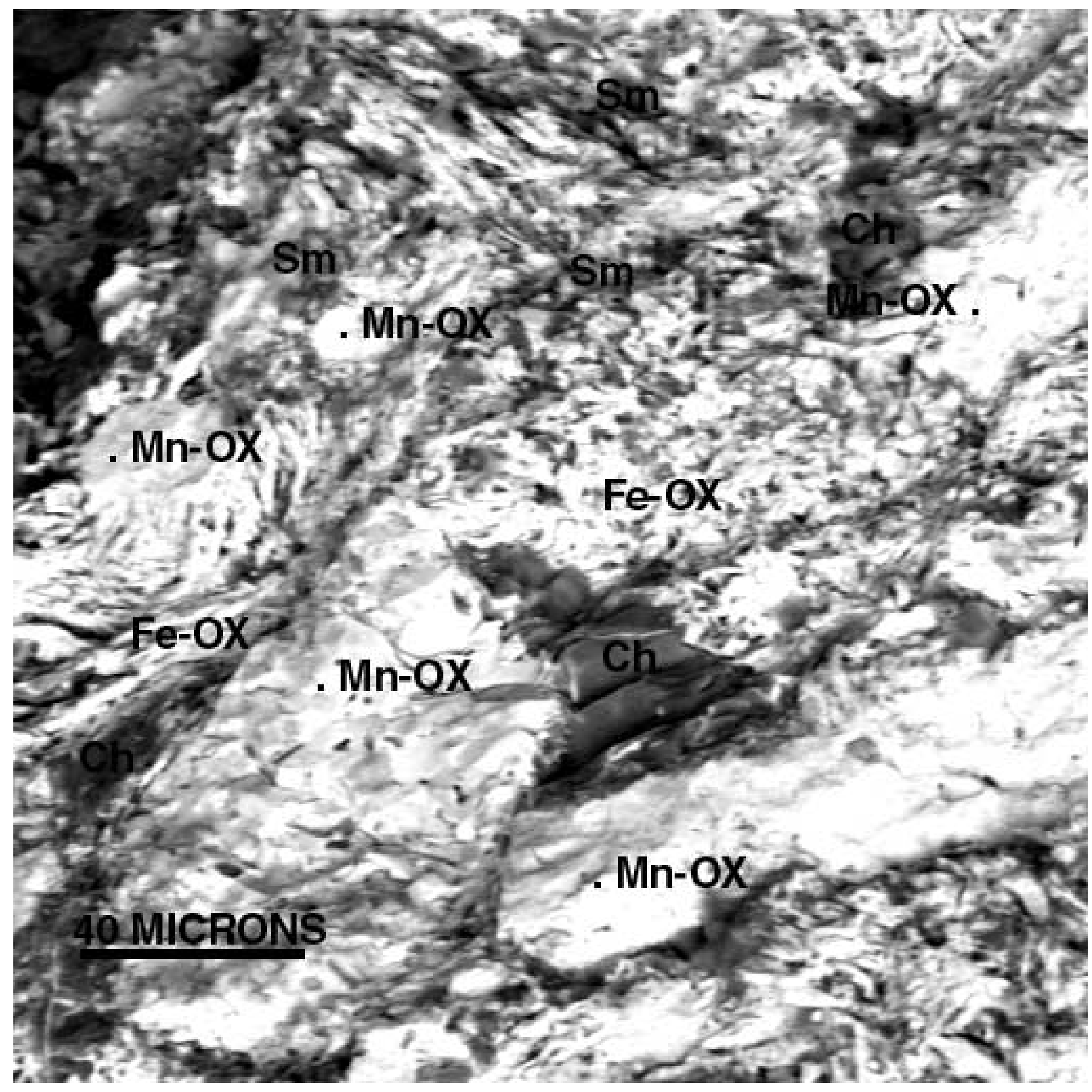

Figure 18. ER-EC-4, 2110-2120 feet. Back scattered electron image showing a close-up view of the inset indicated on Figure 17. Phases include a complex mixture of Ba-bearing $\mathrm{Mn}$-oxide ( $\mathrm{Mn}-\mathrm{OX}$ ) with $\mathrm{Fe}$-oxide (Fe-OX), chalcedony (ch), and smectite $(\mathrm{sm})$. 


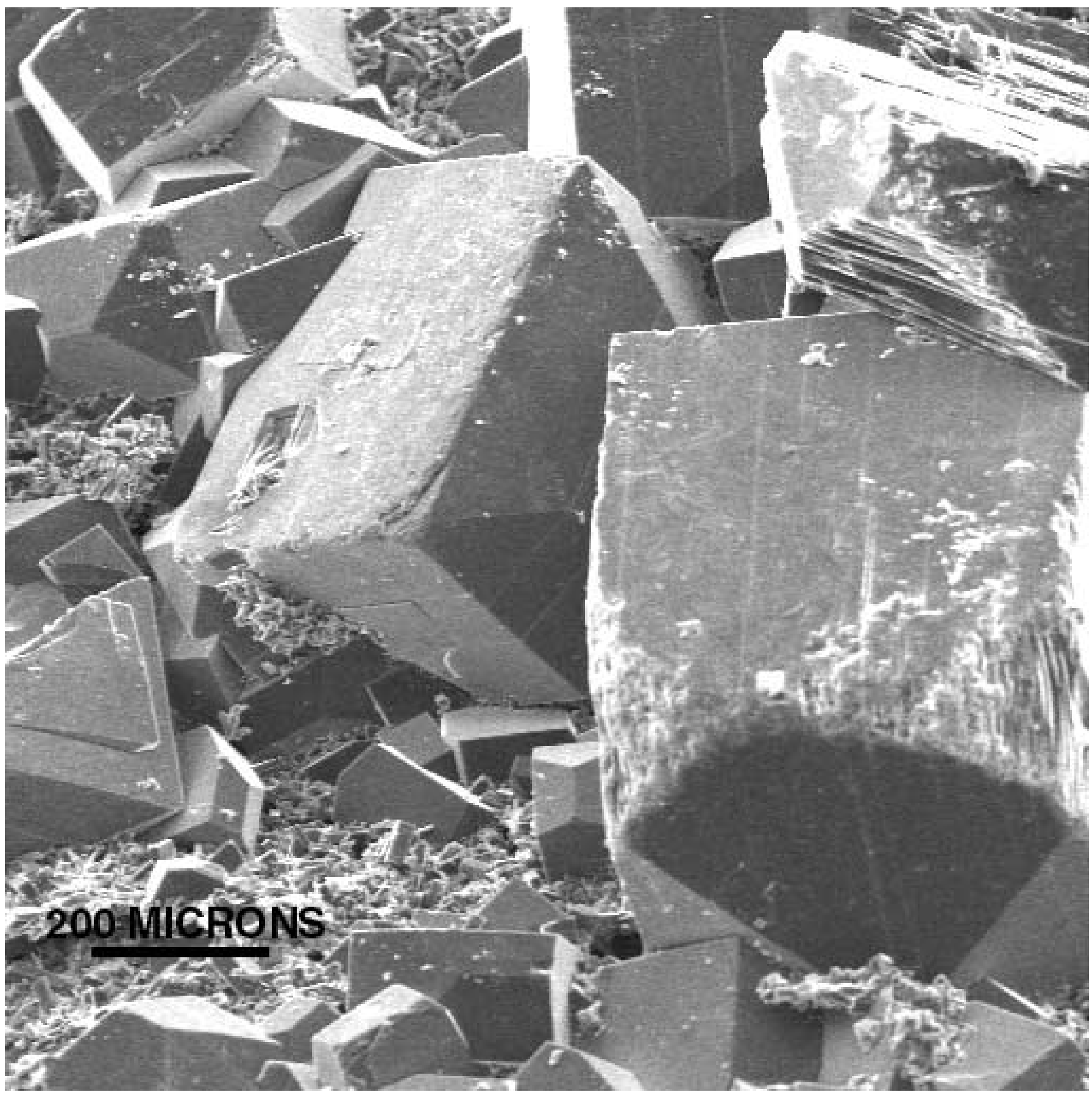

Figure 19. ER-EC-4, 2240-2250 feet. Secondary electron image showing large blocky euhedral zeolite (chabazite?) surrounded by accumulation of finer grained intergrown euhedral zeolite (philipsite?). Eroded corners are thought to be a result of abrasion during drilling and sample recovery. 


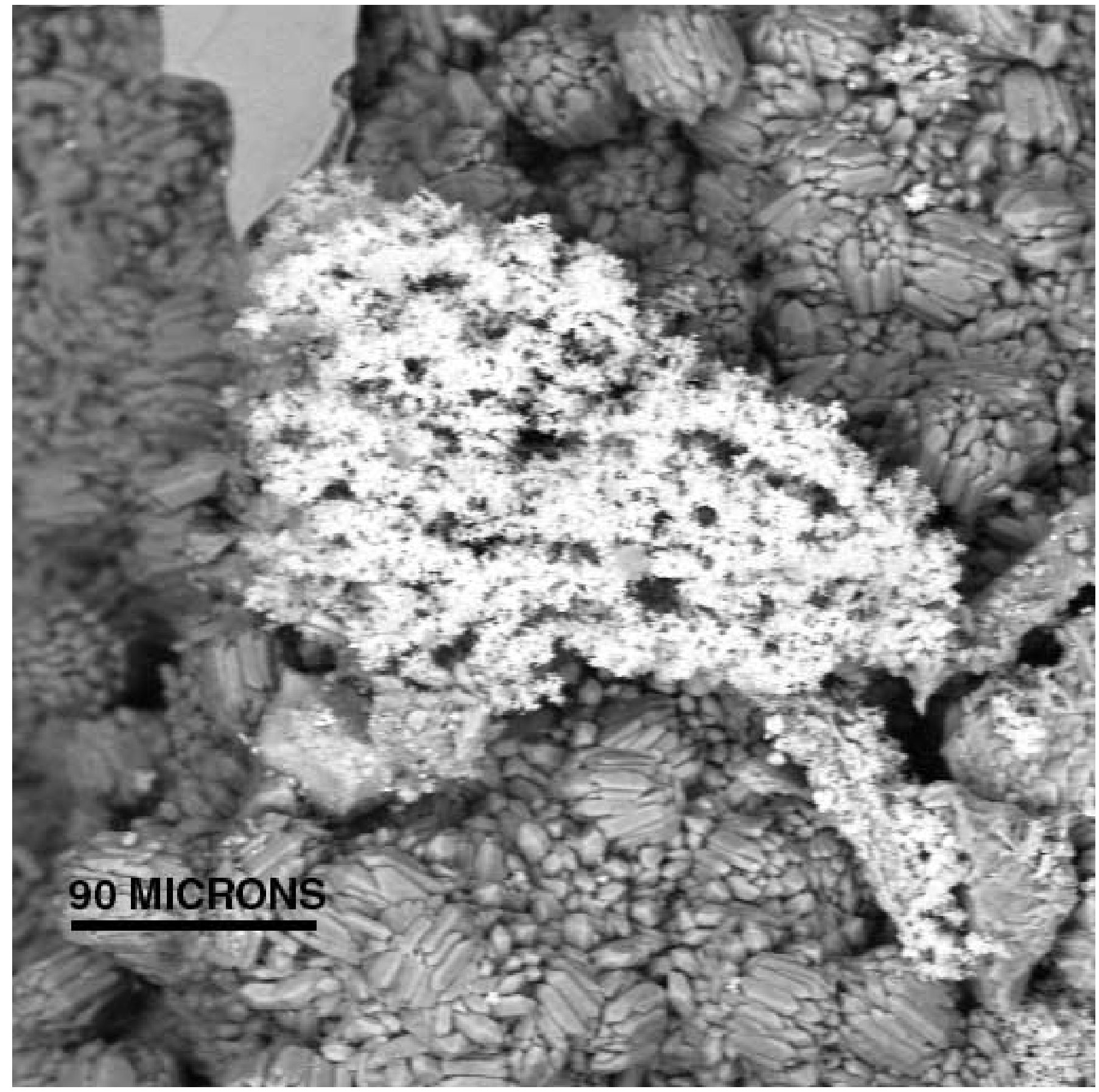

Figure 20. ER-EC-4, 3300 feet. Back scattered electron image showing dendritic Fe-oxide cluster developed on accumulation of sub-spherical aggregates of euhedral to subhedral quartz crystals. 


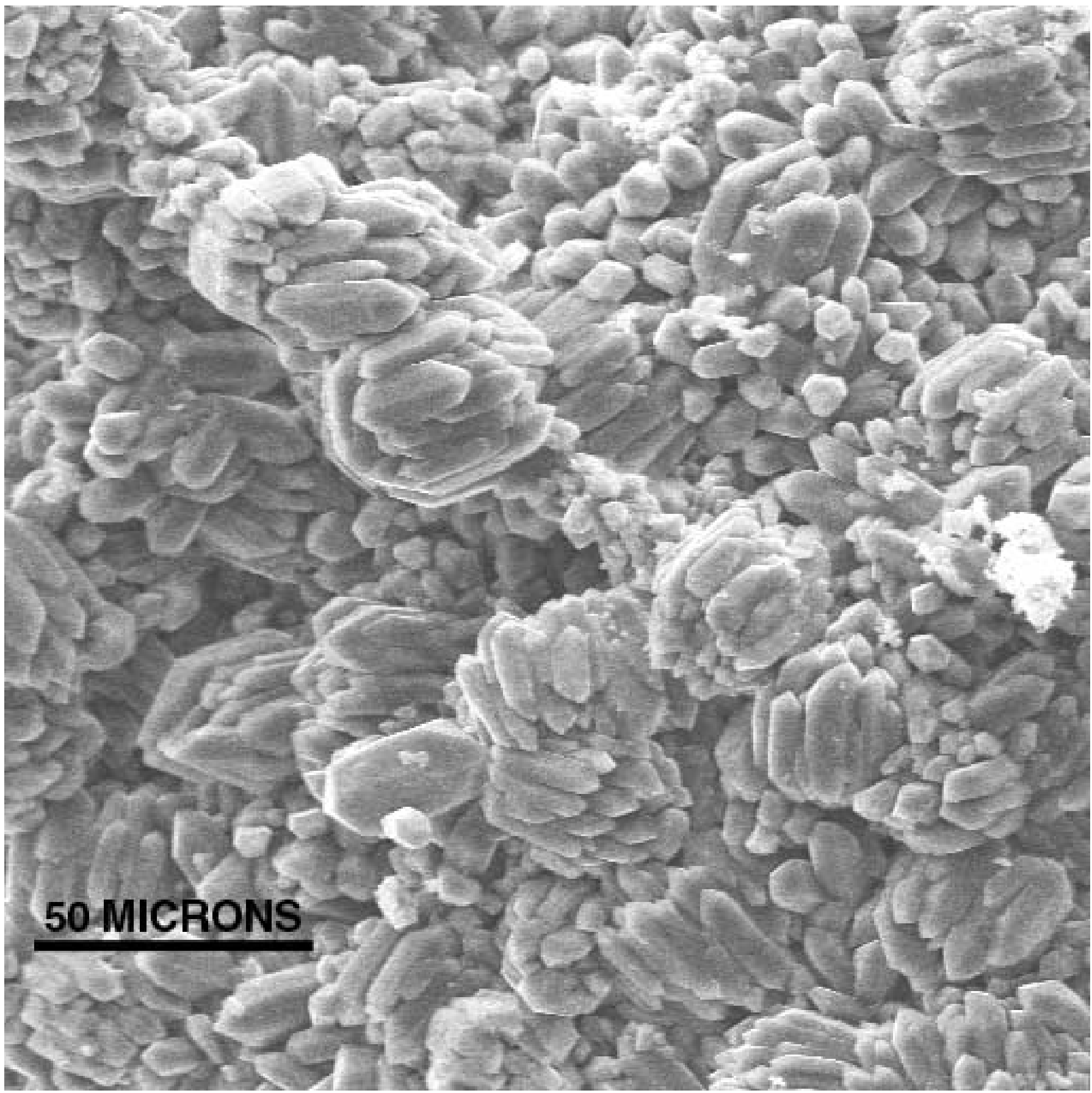

Figure 21. ER-EC-4, 3300 feet. Secondary electron image of sub-spherical aggregates of euhedral to subhedral quartz crystals as shown in Figure 20. 


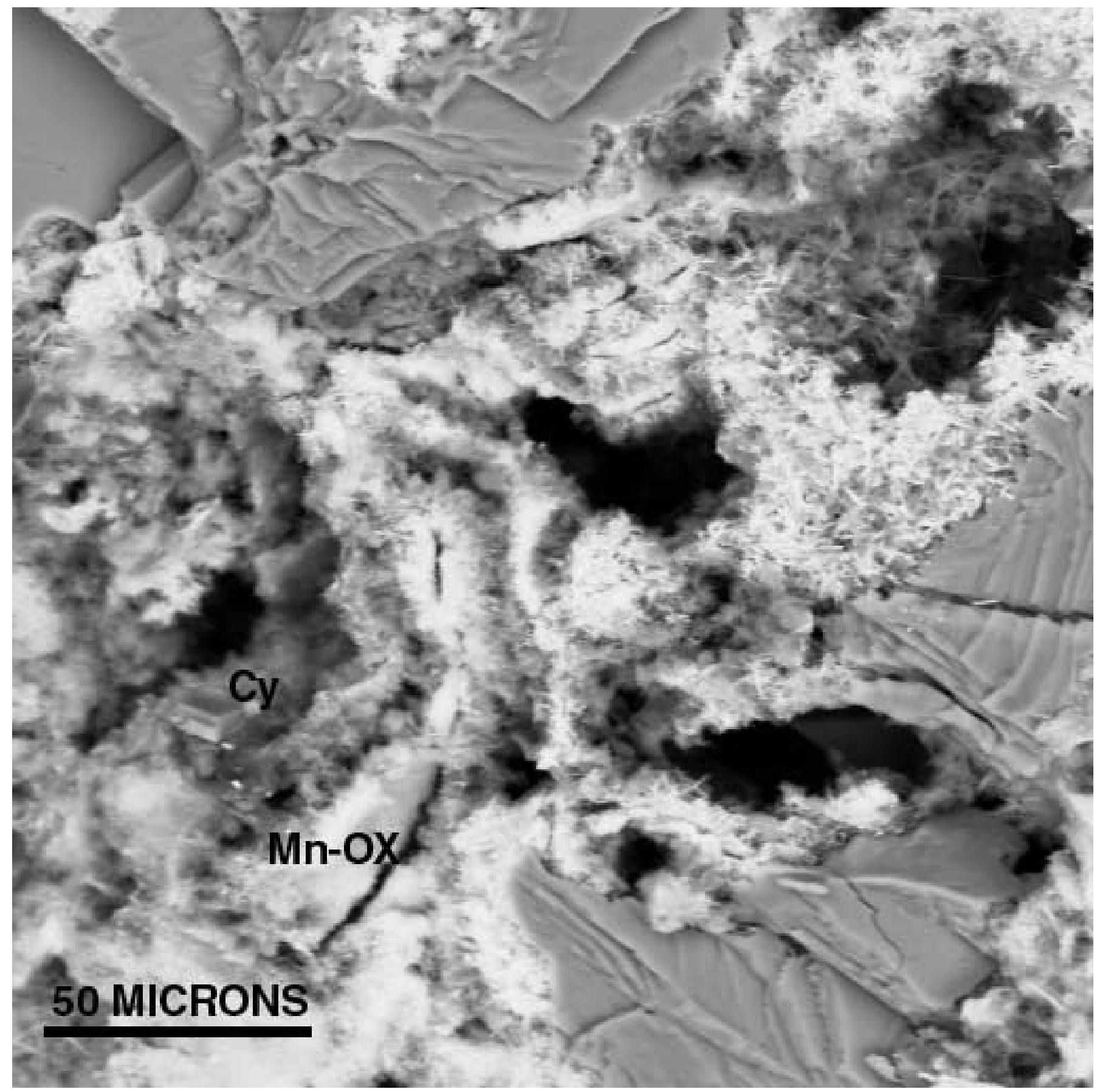

Figure 22. ER-EC-5, 1200 feet. Back scattered electron image of Mn-oxides (Mn-OX) and clays (cy) lining irregular, intersecting fractures. 


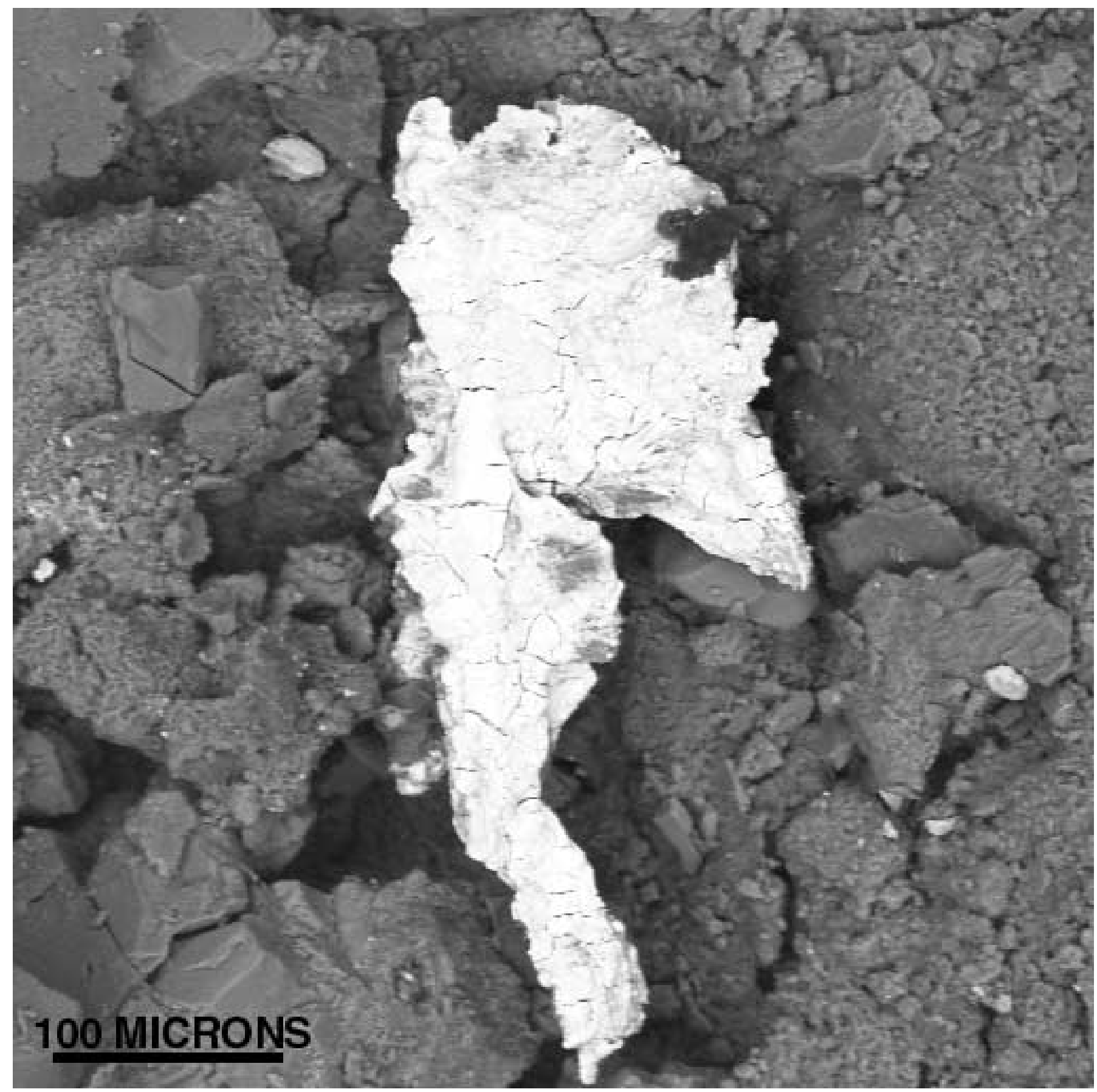

Figure 23. ER-EC-5, 1440 feet. Back scattered electron image of possible cuprotungstite as massive irregular grain with abundant dessication cracks on fracture surface. 


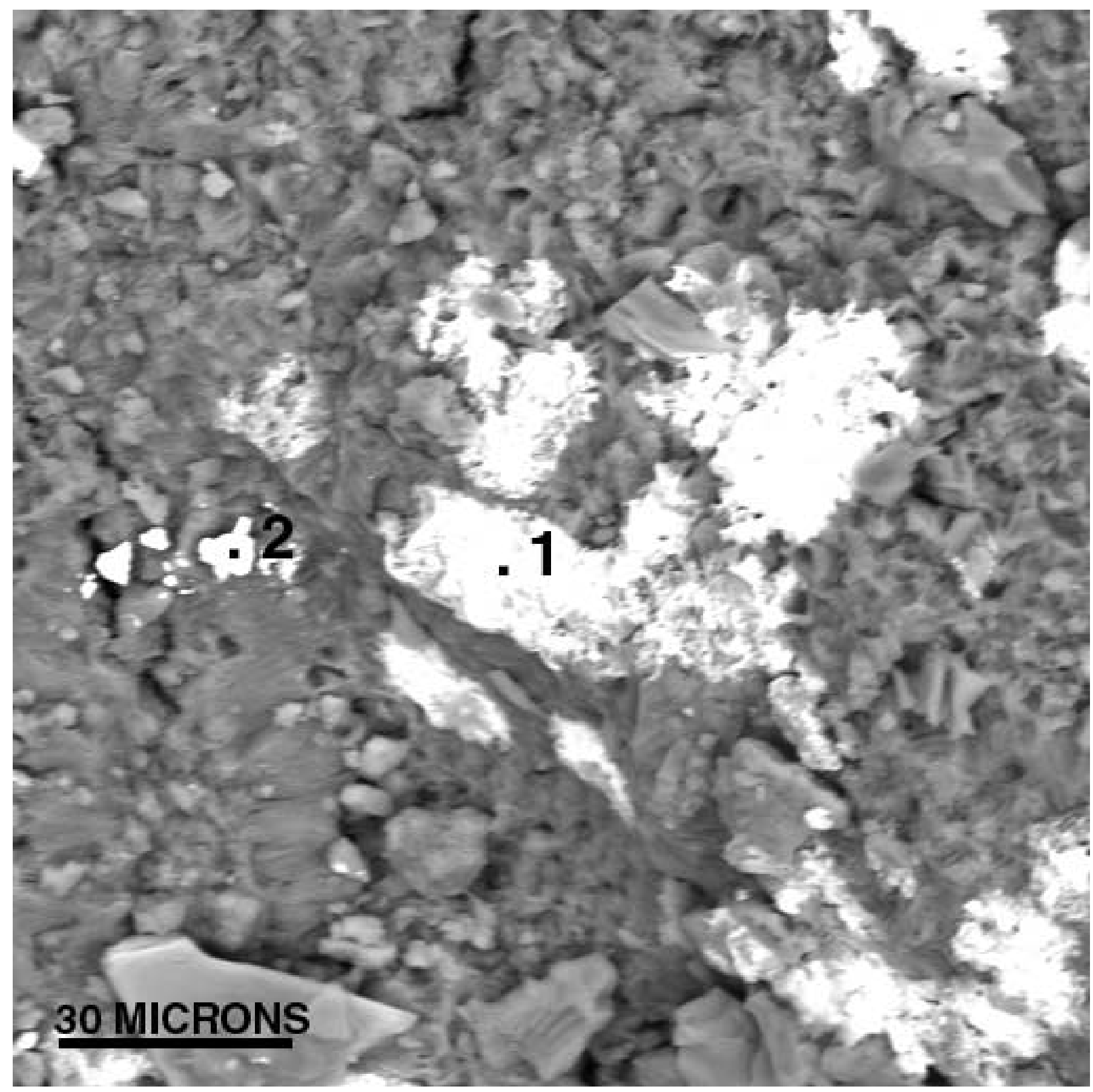

Figure 24. ER-EC-5, 1440 feet. Back scattered electron image of eroded scheelite (1) adjacent to small anhedral grains of barite (2) on fracture surface. 


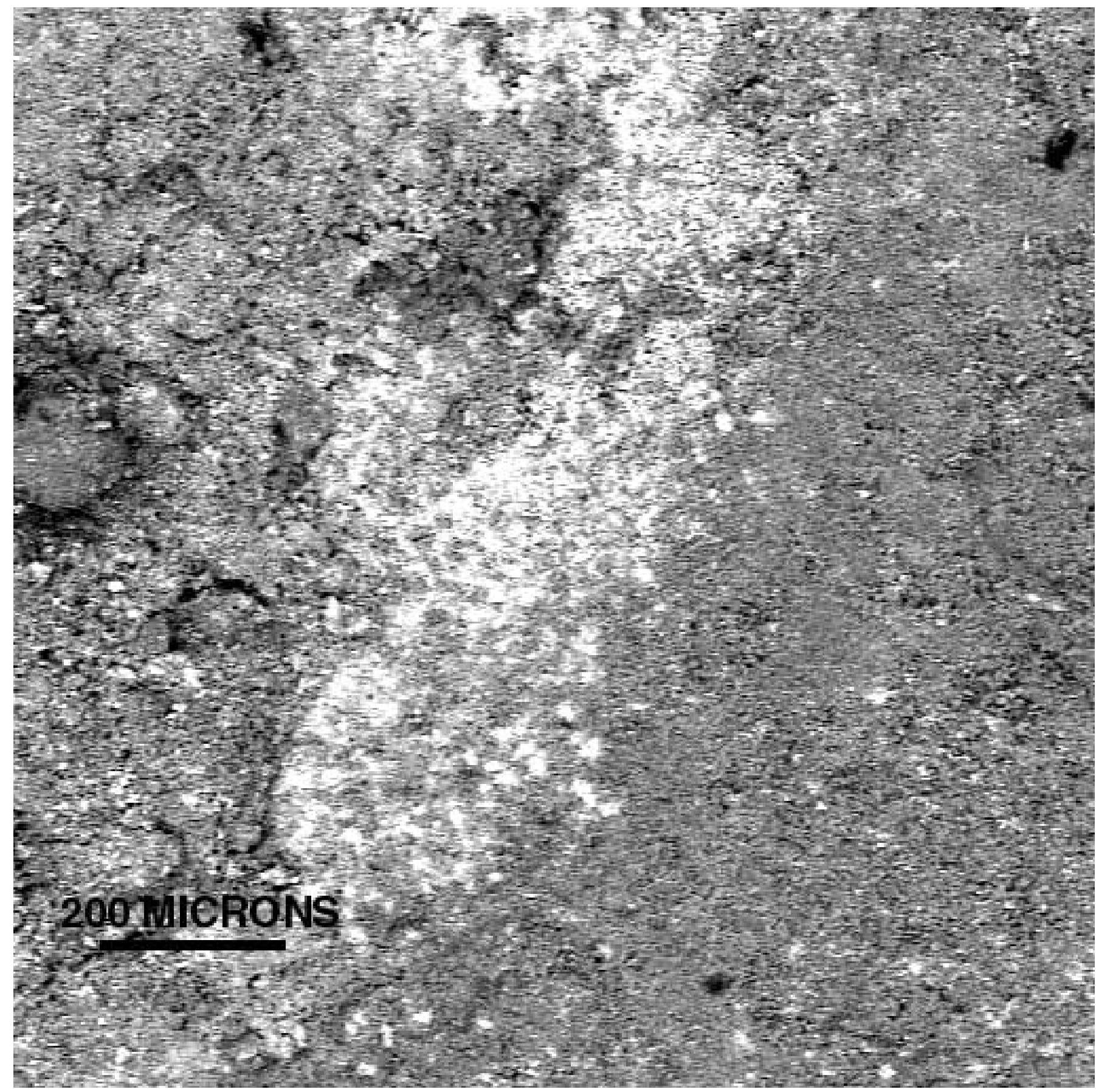

Figure 25. ER-EC-5, 2105 feet. Back scattered electron image showing disseminated Fe-oxides (high contrast) on fracture surface covered predominantly by clays and chalcedony. 


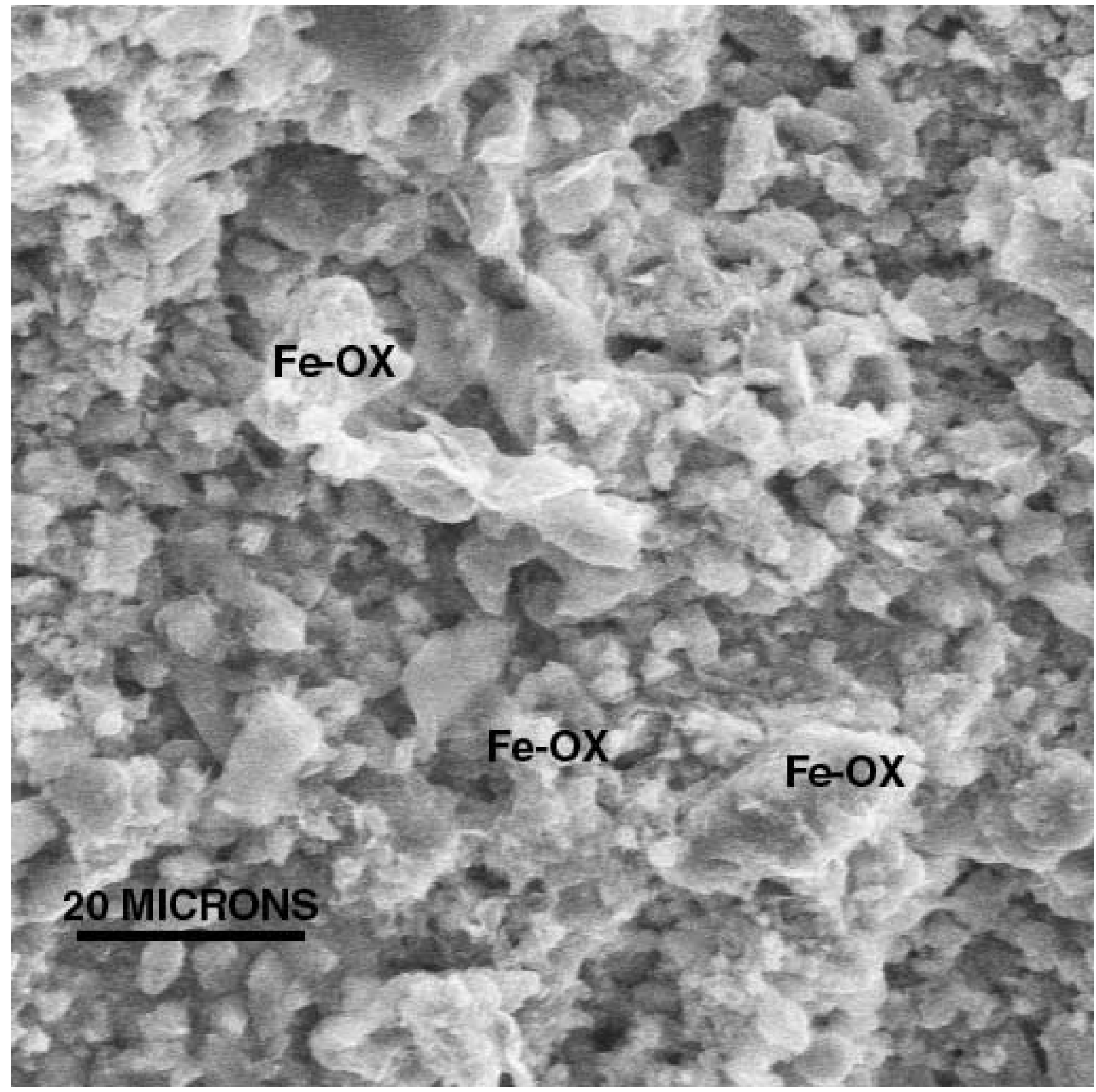

Figure 26. ER-EC-5, 2105 feet. Secondary electron image showing fine grained granular nature of fracture surface. Fractured coating is comprised of Fe-oxides (Fe-OX) and a mixture of clays (probable illite plus smectite) and chalcedony. 


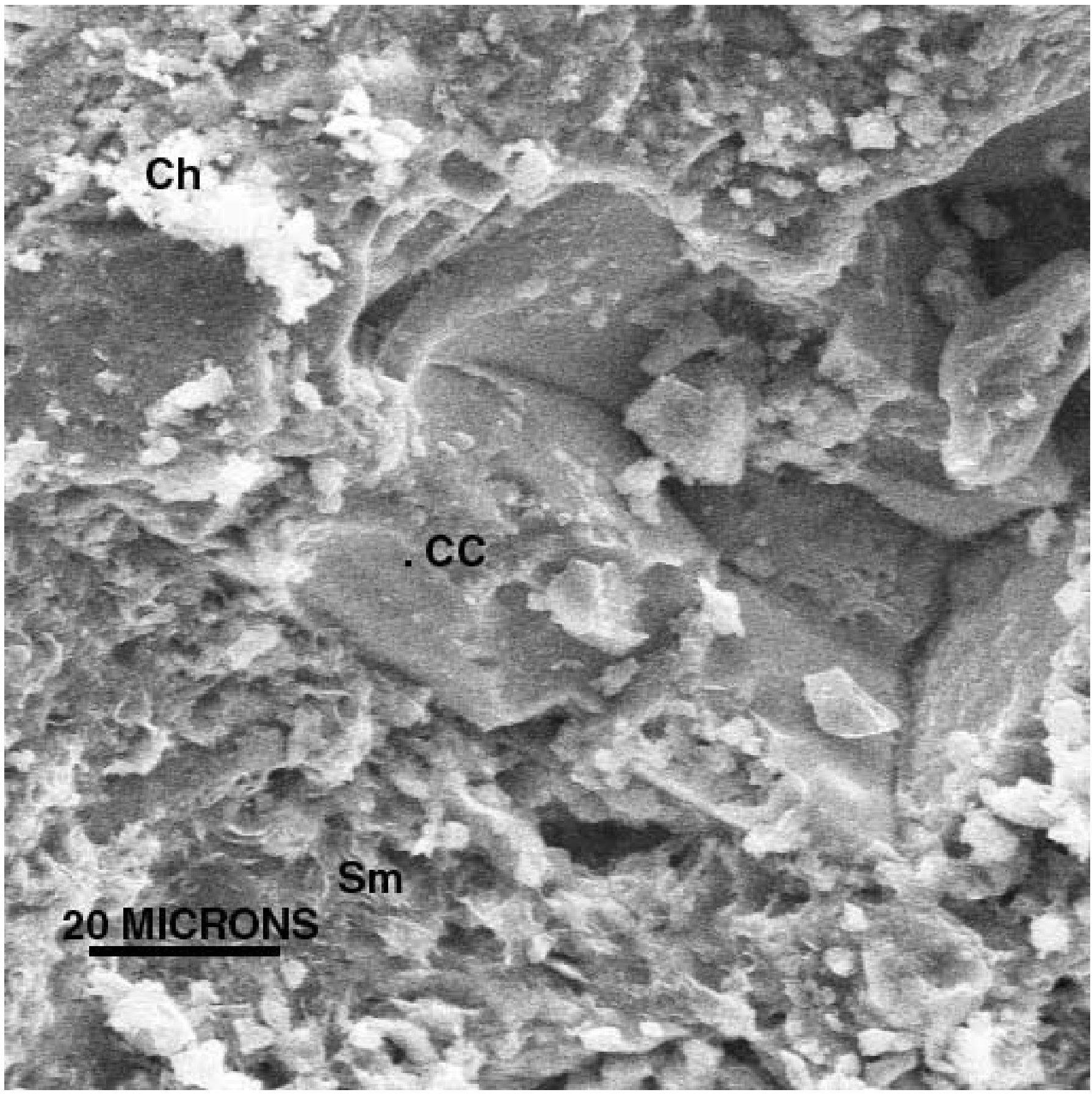

Figure 27. ER-EC-5, 2135 feet. Secondary electron image showing eroded calcite (CC) from sample matrix exposed on fracture surface and partially coated by chalcedony (Ch) and smectite $(\mathrm{Sm})$. 


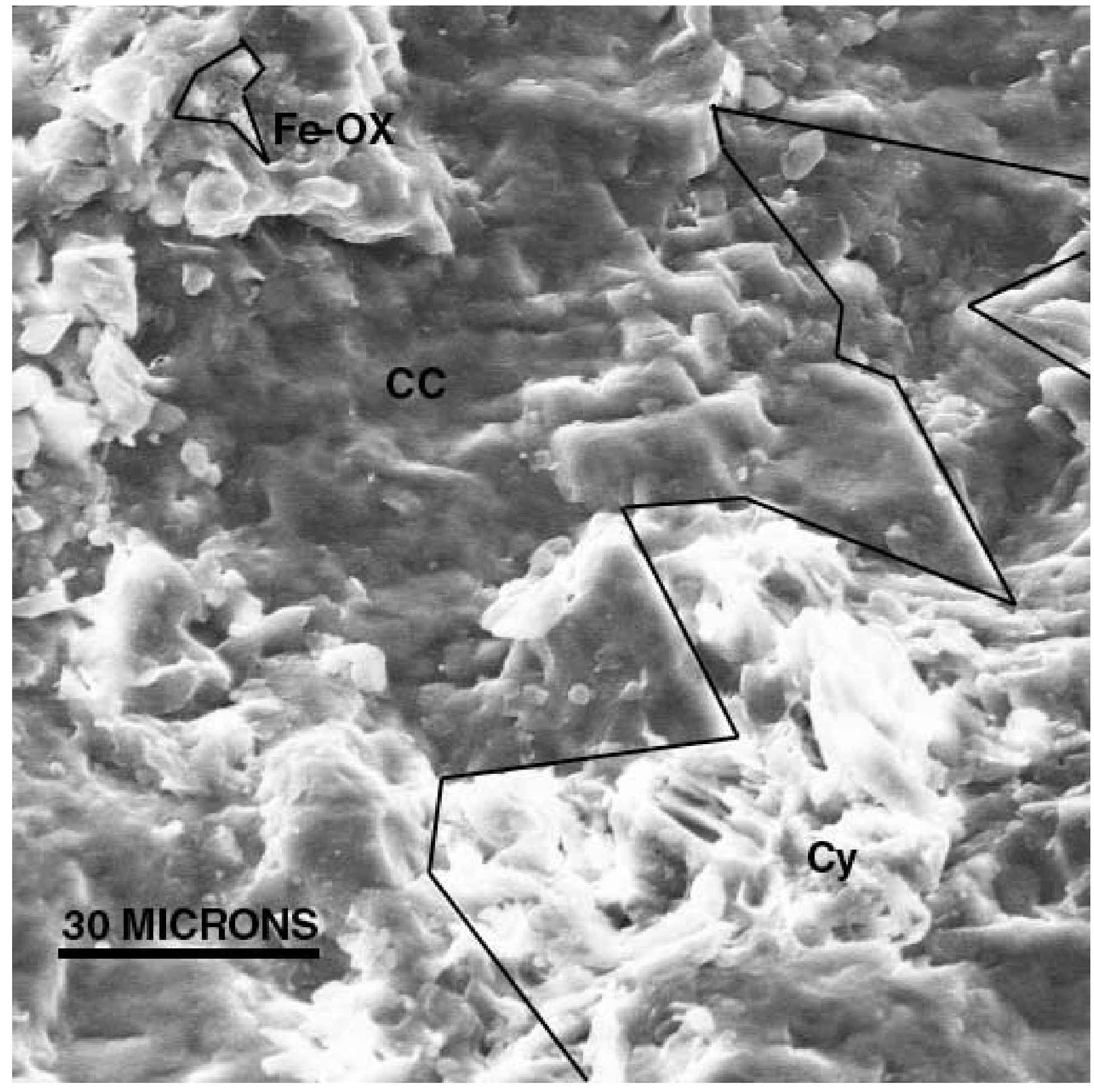

Figure 28. ER-EC-6, 2415 feet. Secondary electron image showing eroded calcite (CC) with superjacent (predominantly illite) clay (Cy) and Fe-oxide (Fe-OX). 


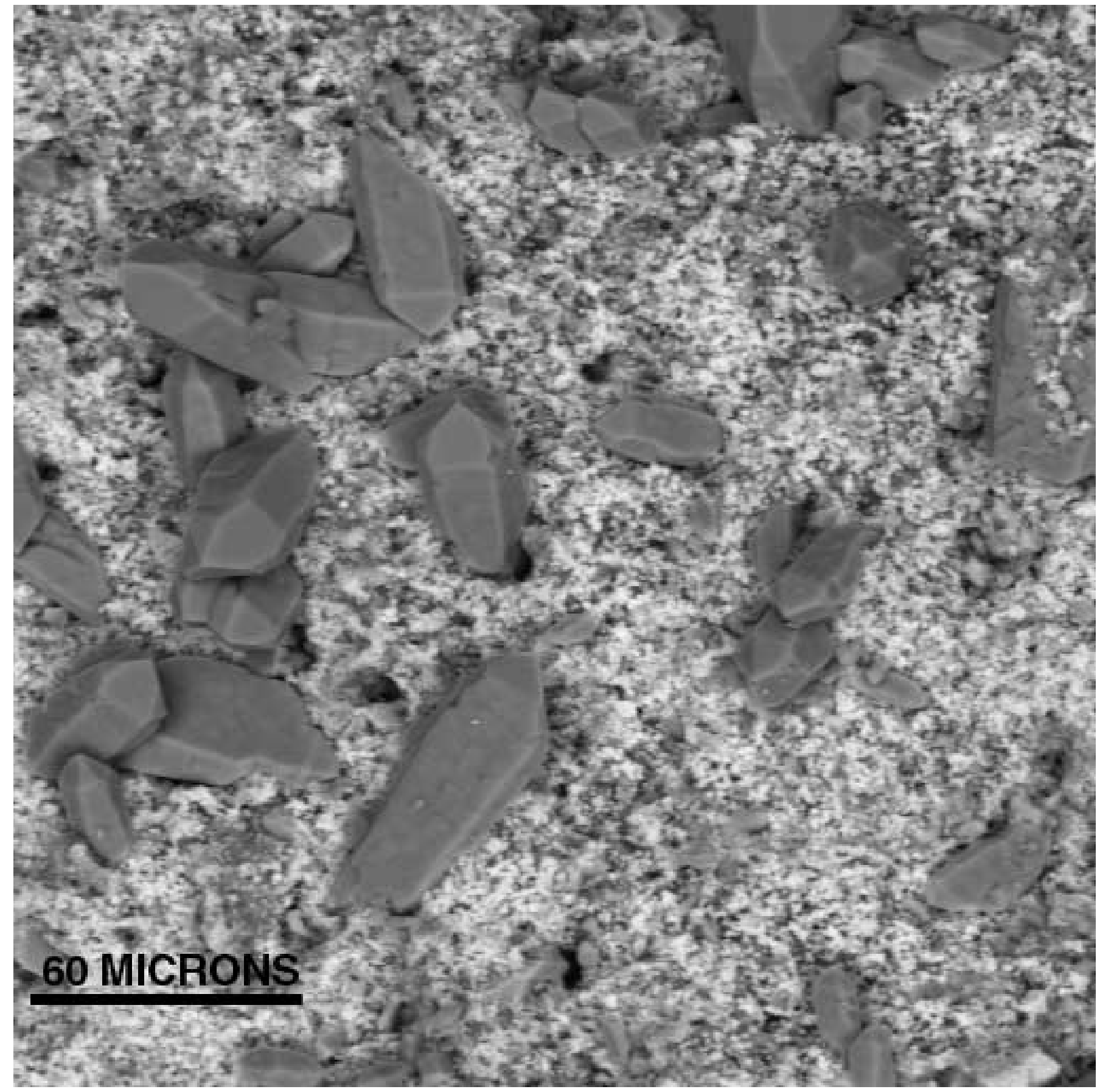

Figure 29. ER-EC-6, 2445 feet. Back scattered electron image showing quartz crystals surrounded by Fe-oxide and smectite mixture. 


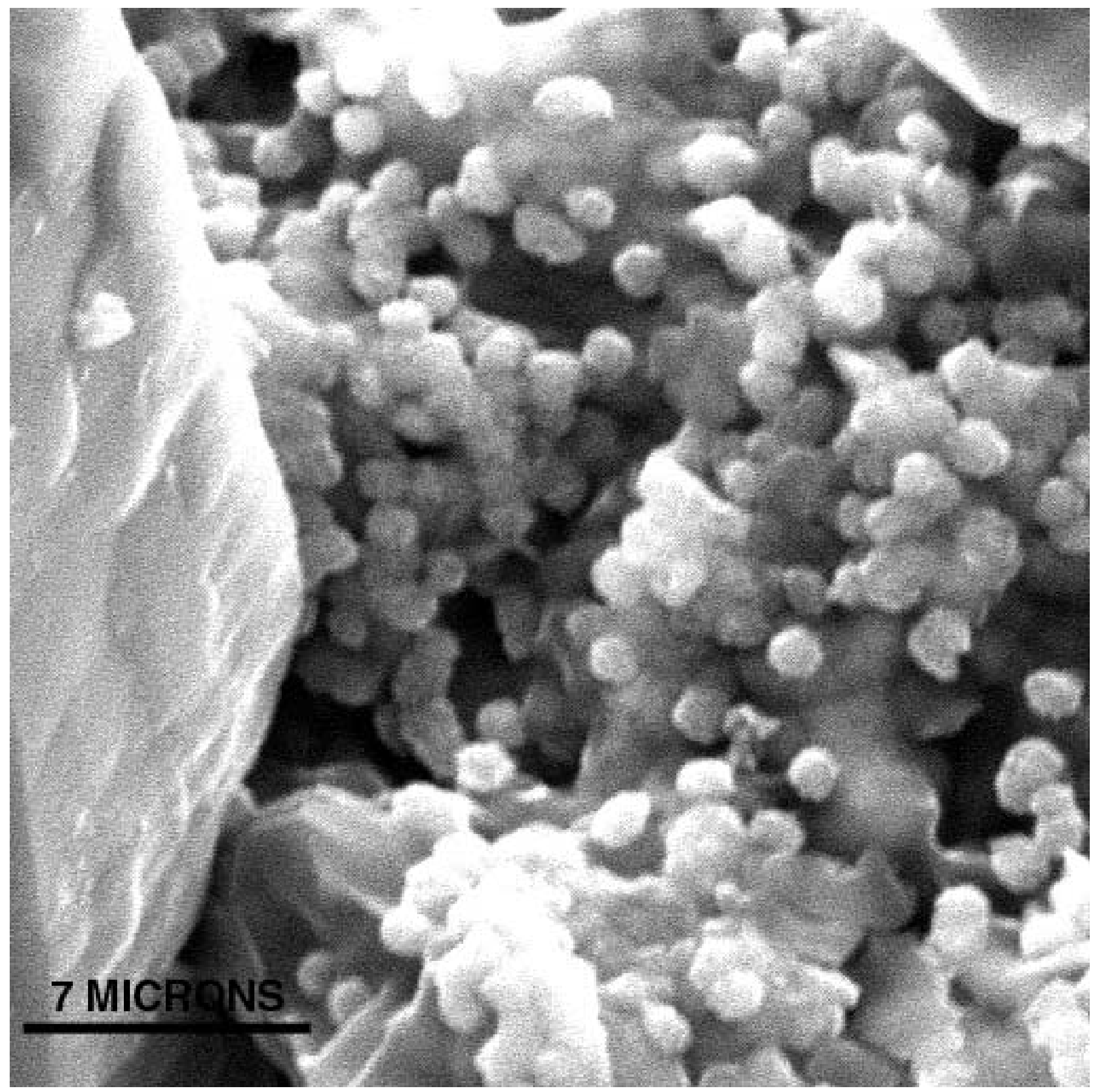

Figure 30. ER-EC-6, 2445 feet. Secondary electron image showing close-up view of rounded to botryoidal Fe-oxide with smectite adjacent to eroded quartz crystal. 


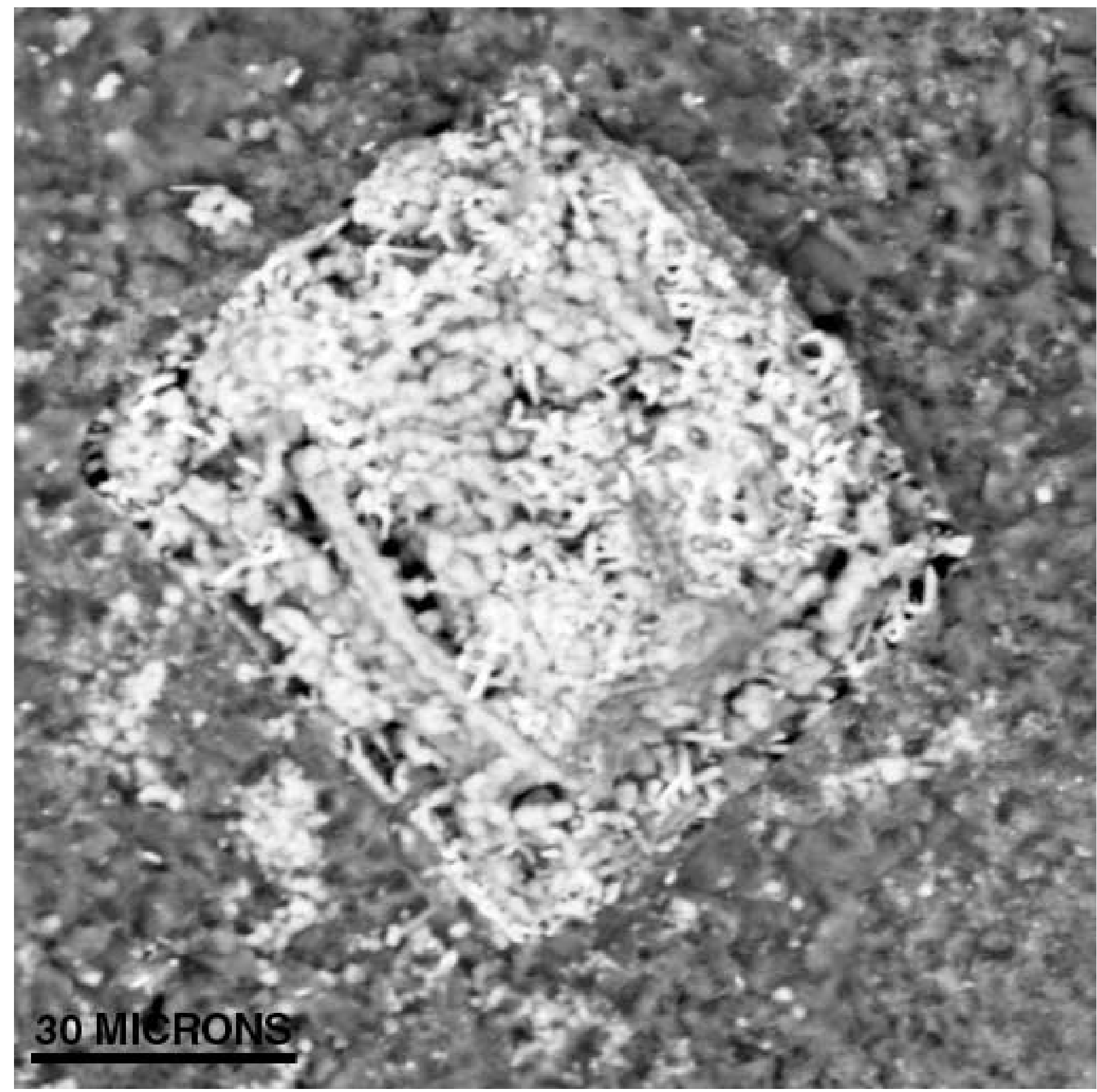

Figure 31. ER-EC-6, 2445 feet. Back scattered electron image showing polyphase (predominantly Fe-oxide) aggregate pseudomorph after pyrite. 


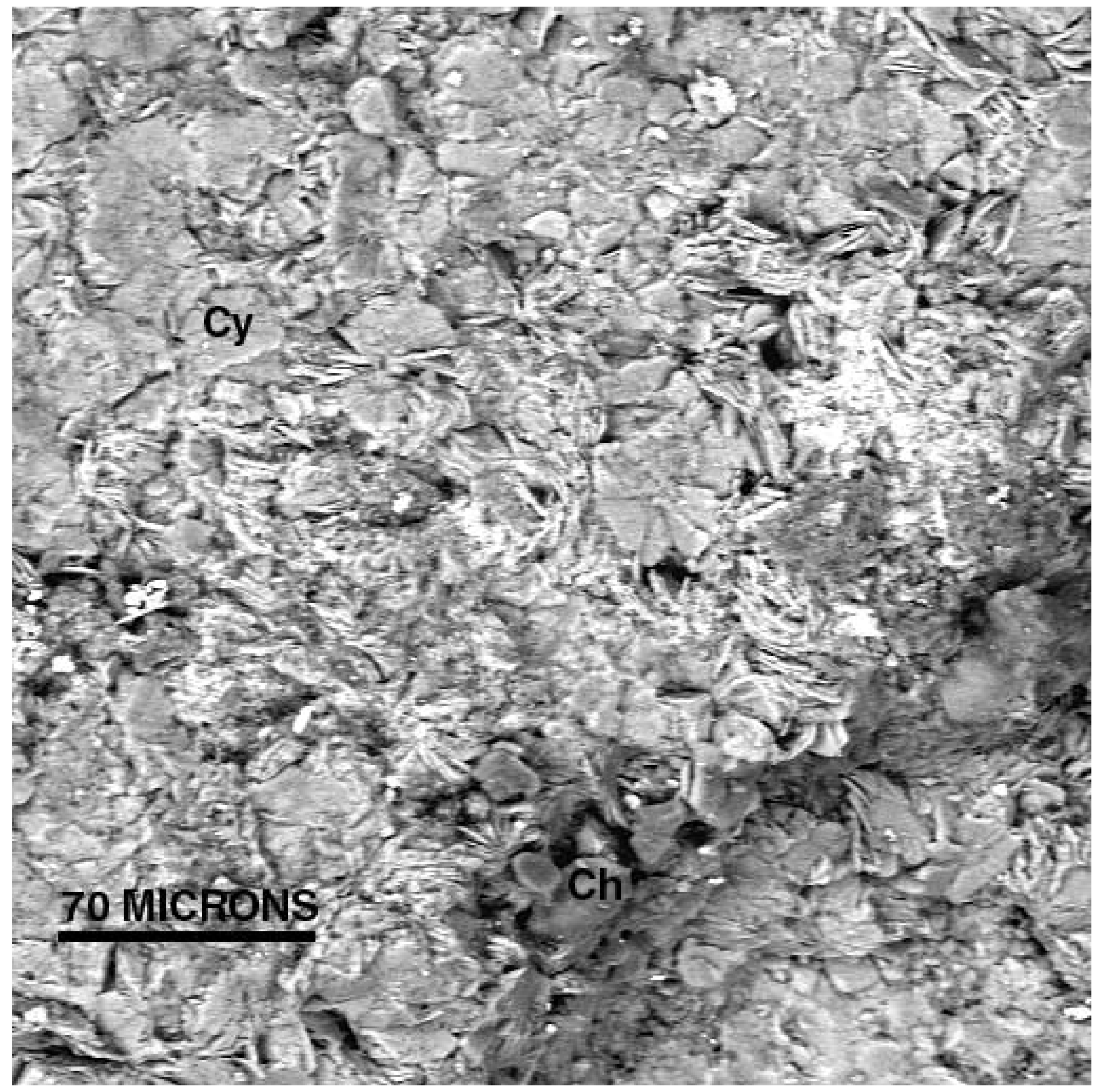

Figure 32. ER-EC-6, 3445 feet. Back scattered electron image showing ragged clay plates and platy aggregates (Cy) with irregular blocky chalcedony $(\mathrm{Ch})$. 


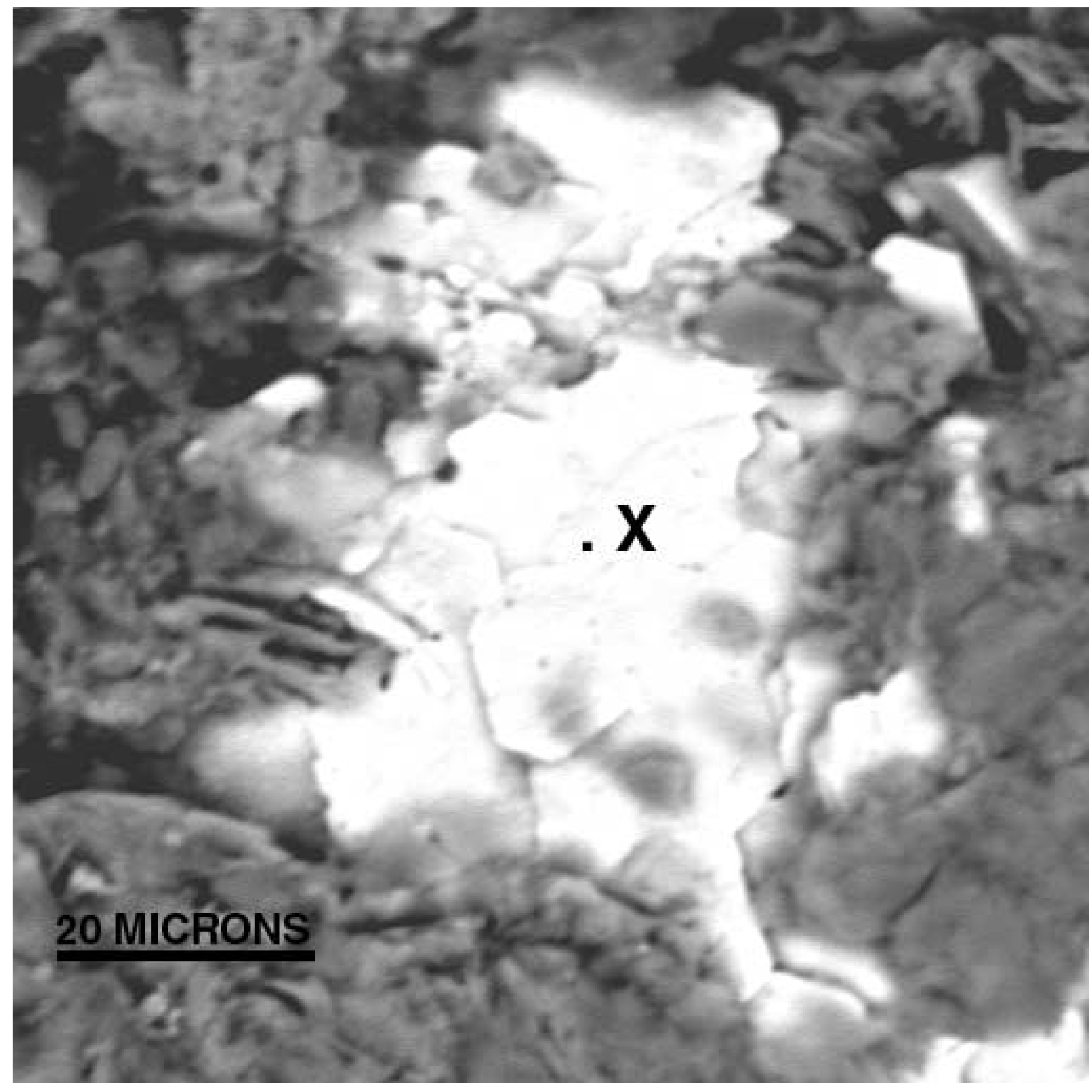

Figure 33. ER-EC-6, 3445 feet. Back scattered electron image showing irregular REE-bearing phase (carbonate?). Analysis point for EDS spectrum shown in Figure 34 indicated by "X". 


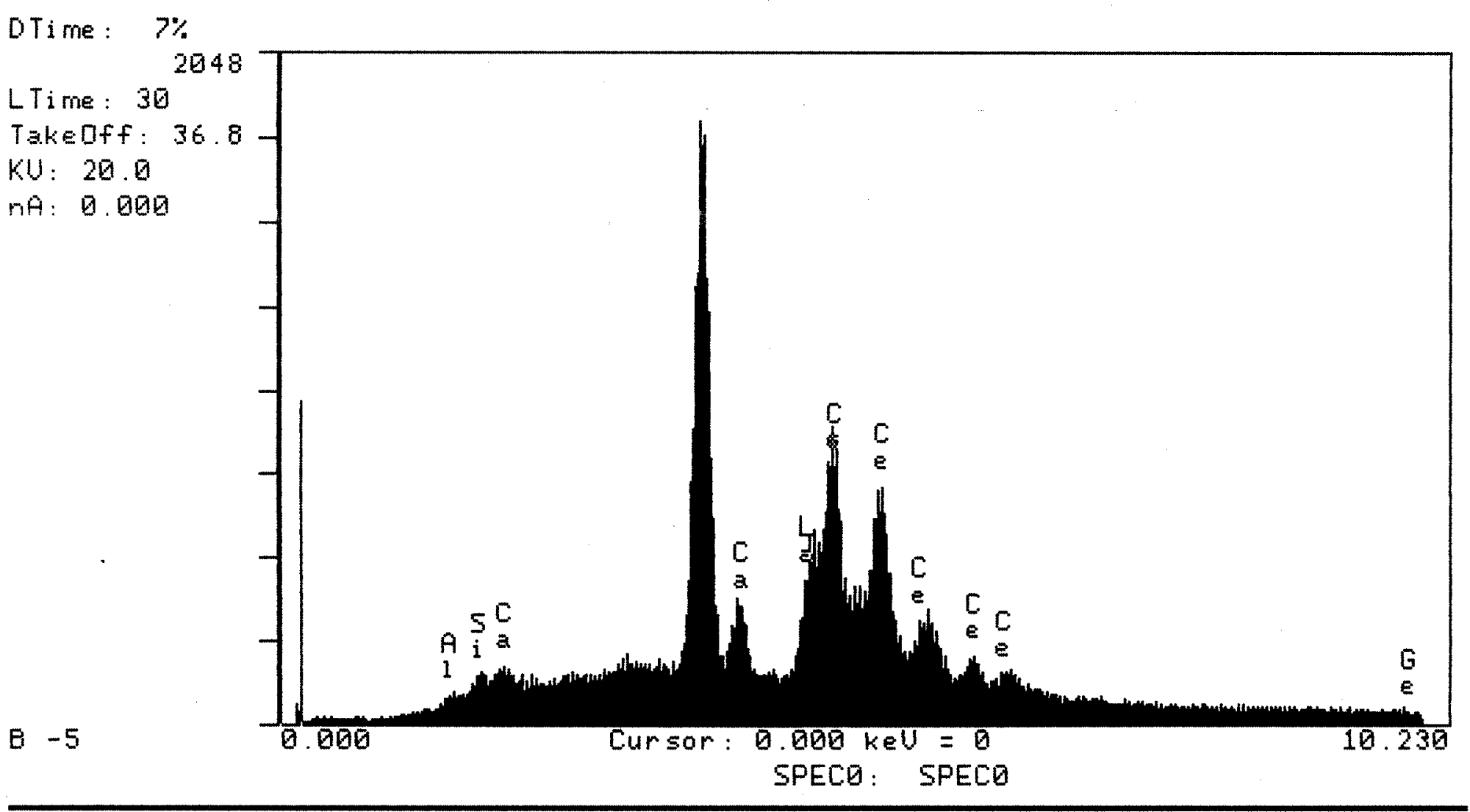

Figure 34. ER-EC-6, 3445 feet. EDS spectrum for analysis point on high contrast phase shown in Figure 33. 


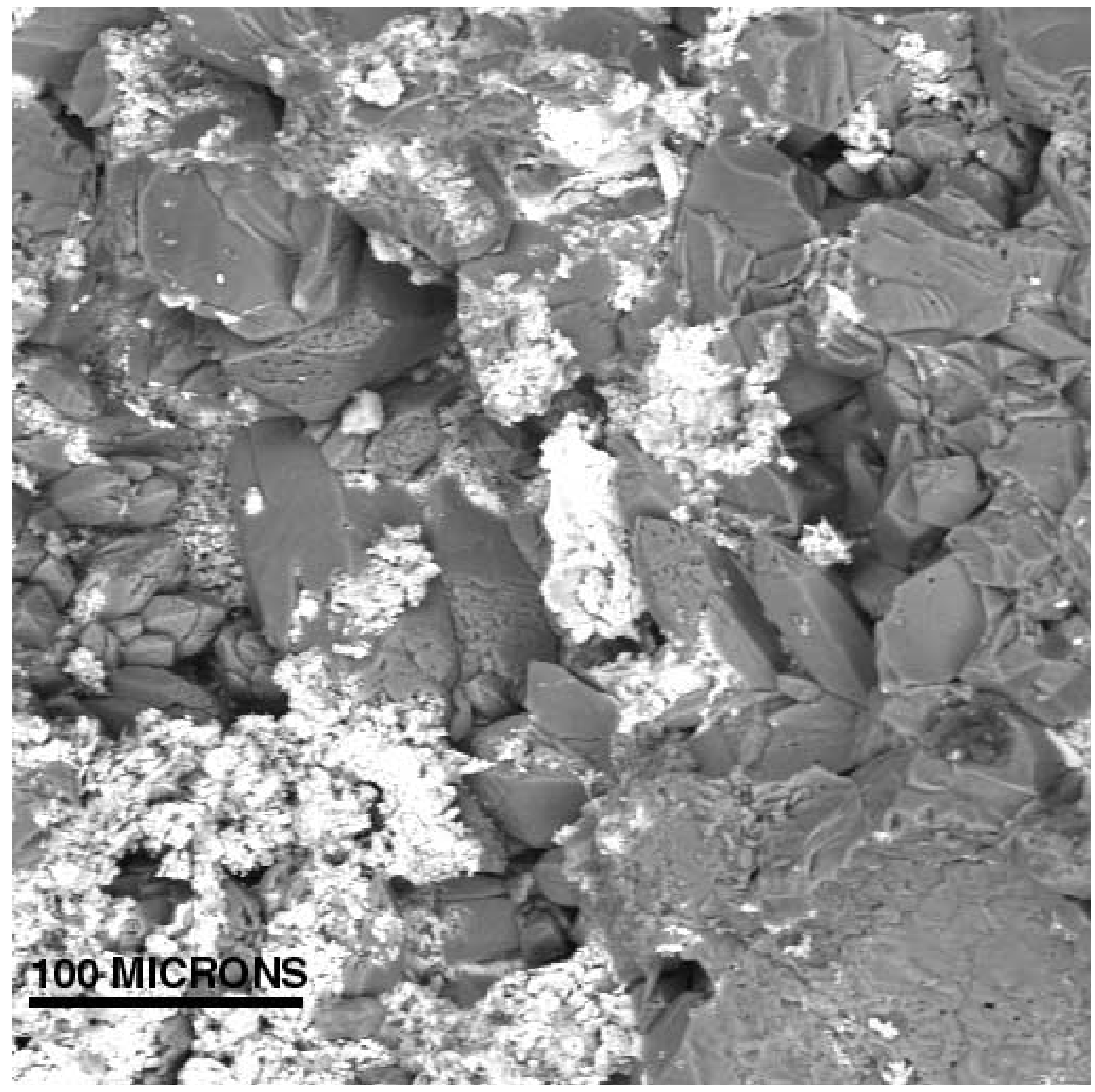

Figure 35. ER-EC-7, 940-950 feet. Back scattered electron image showing Ba-bearing Mn-oxide aggregates (high contrast phases) developed between solution etched quartz crystals. 


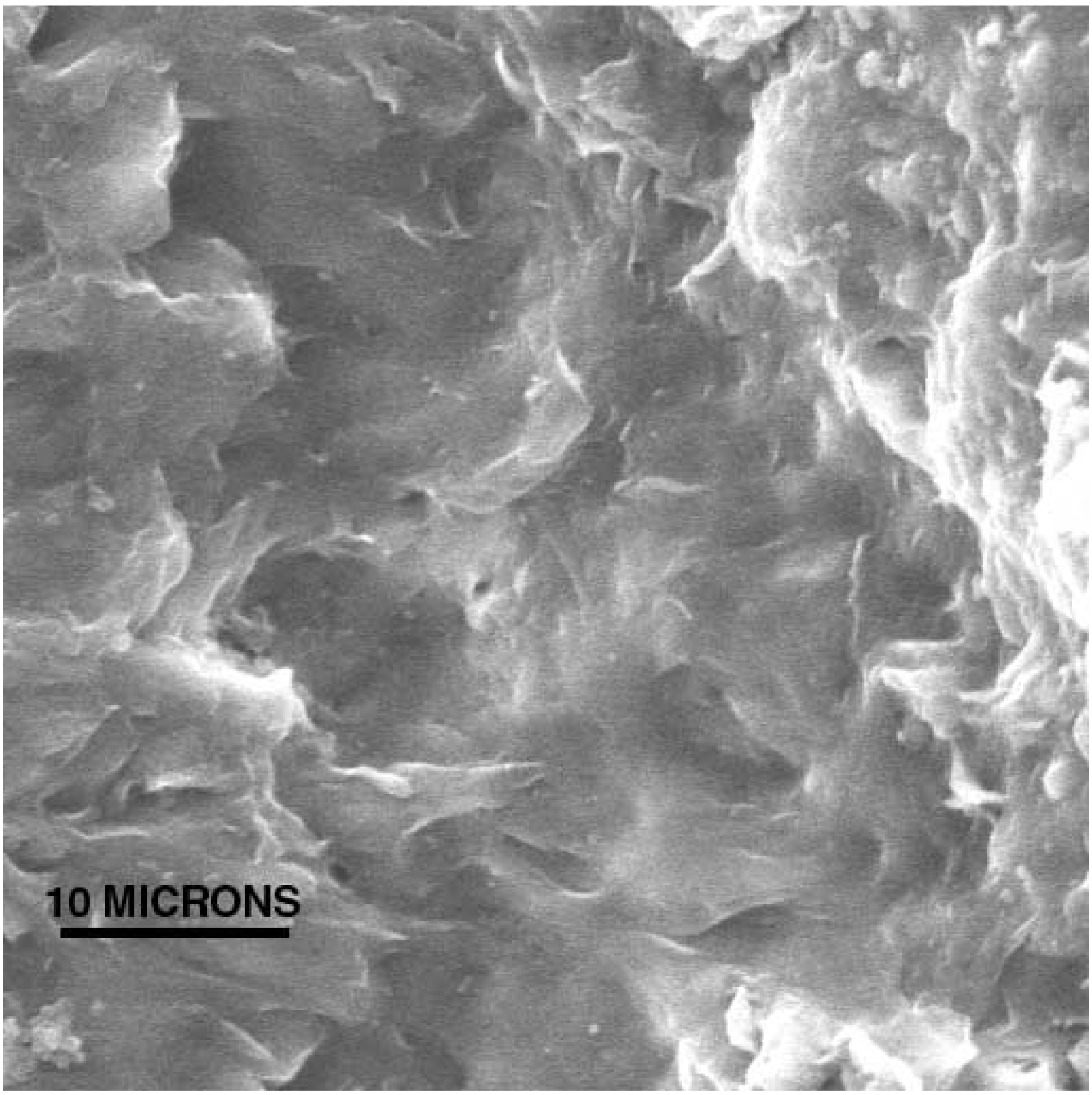

Figure 36. ER-18-2, 1940-1950 feet. Secondary electron image showing clay (smectite?) mat locally developed on fracture surface. 


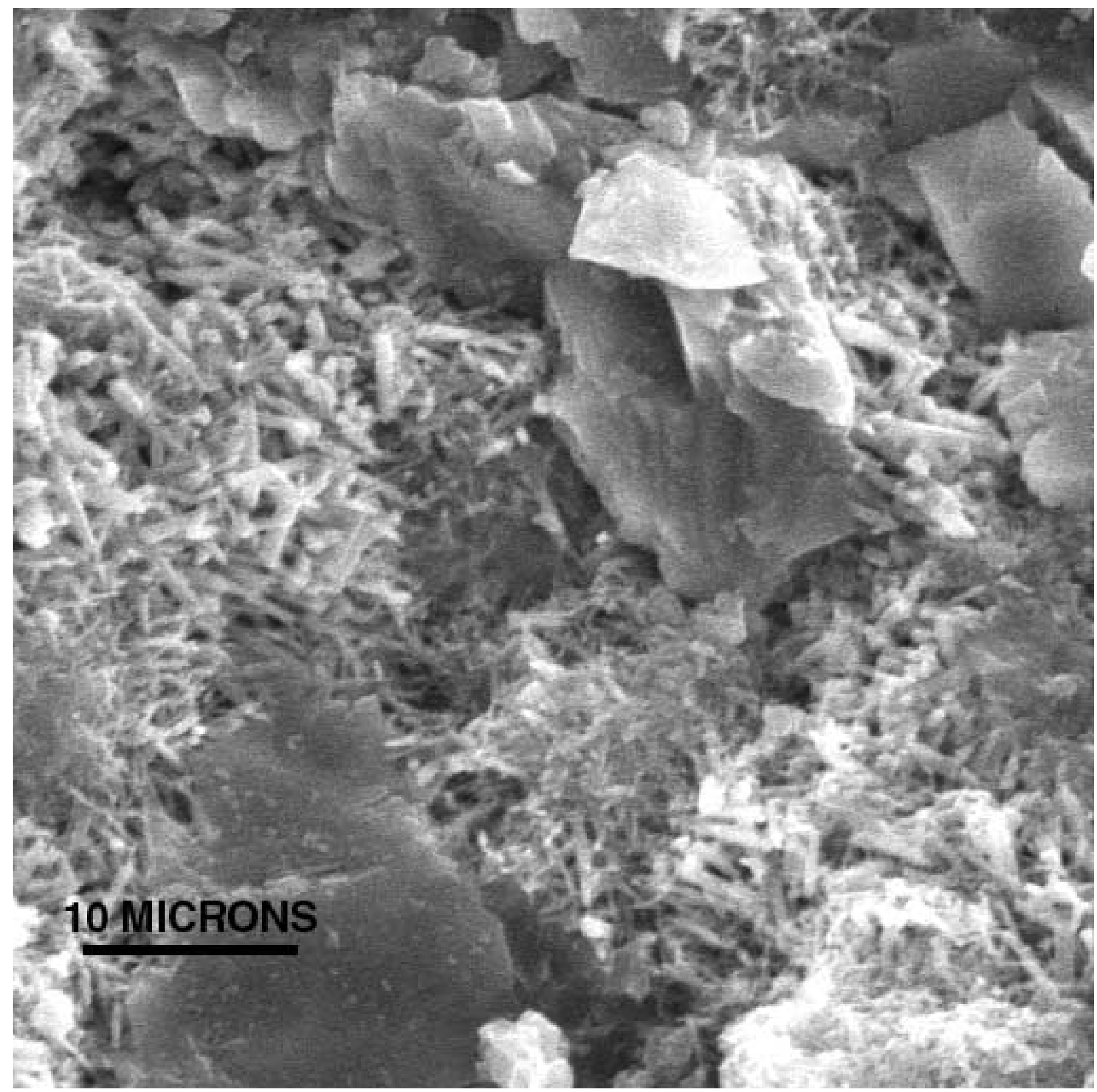

Figure 37. ER-18-2, 1970-1980 feet. Secondary electron image showing aggregates of prismatic Ba-bearing Mn-oxide developed between irregular Mn-bearing calcite grains, which exhibit dissolution features. 


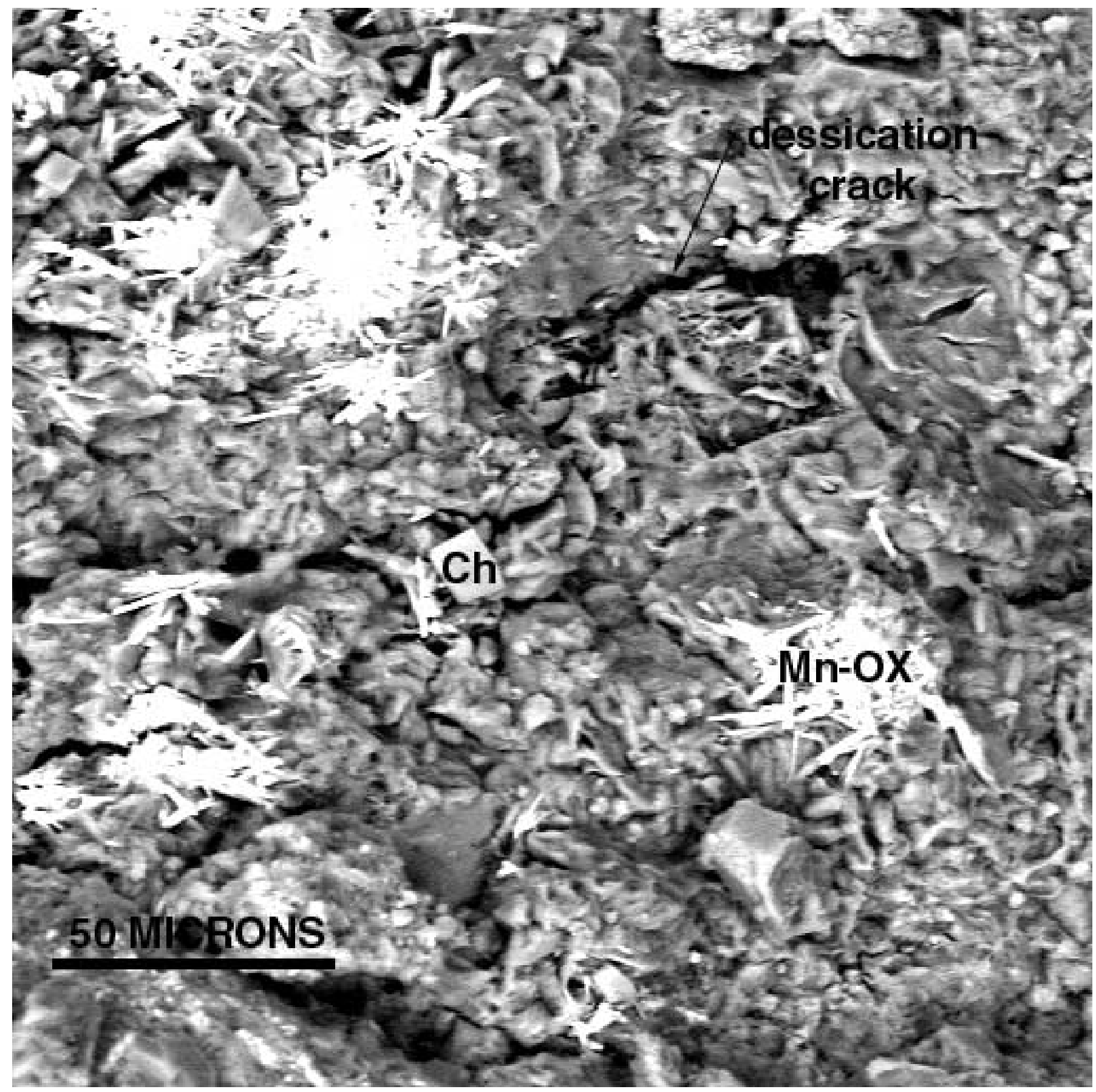

Figure 38. Er-18-2, 2050-2060 feet. Back scattered electron image showing roughly radial aggregates of prismatic $\mathrm{Ba}-$ bearing $\mathrm{Mn}-\mathrm{oxide}(\mathrm{Mn}-\mathrm{OX})$ on largely matted fracture surface dominated by probable smectite clay. The fracture surface is transected from lower left to upper right by what is interpreted to be a dessication crack. Small chalcedony crystals (Ch) are locally present on the fracture surface. 


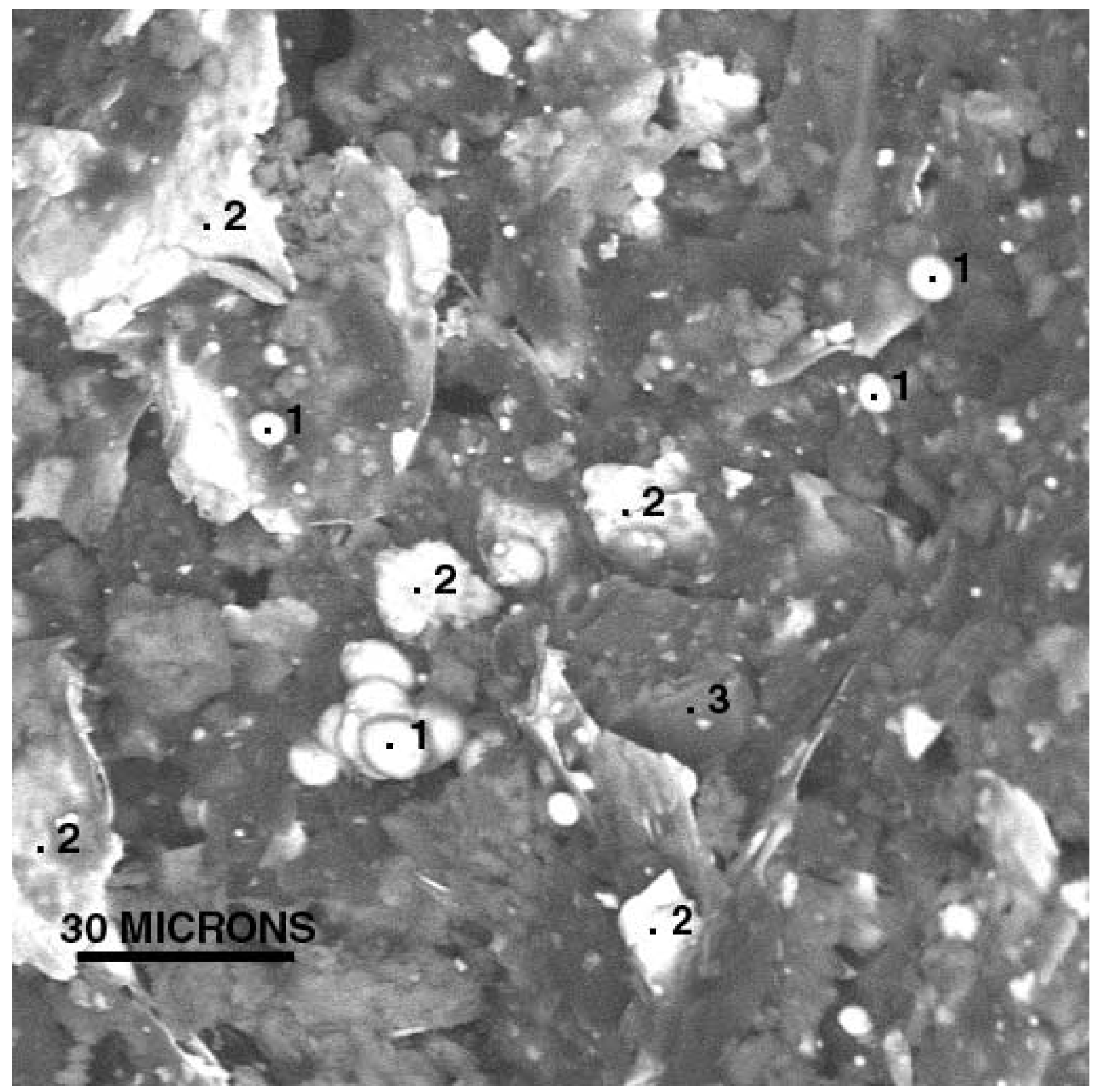

Figure 39. UE-29a\#2, 167.2-167.3 feet. Back scattered electron image showing elemental $\mathrm{Cu}(\mathrm{Cu})$ and spheroidal $\mathrm{Zn}$-silicate? (Zn) in probable opaline silica matrix. 


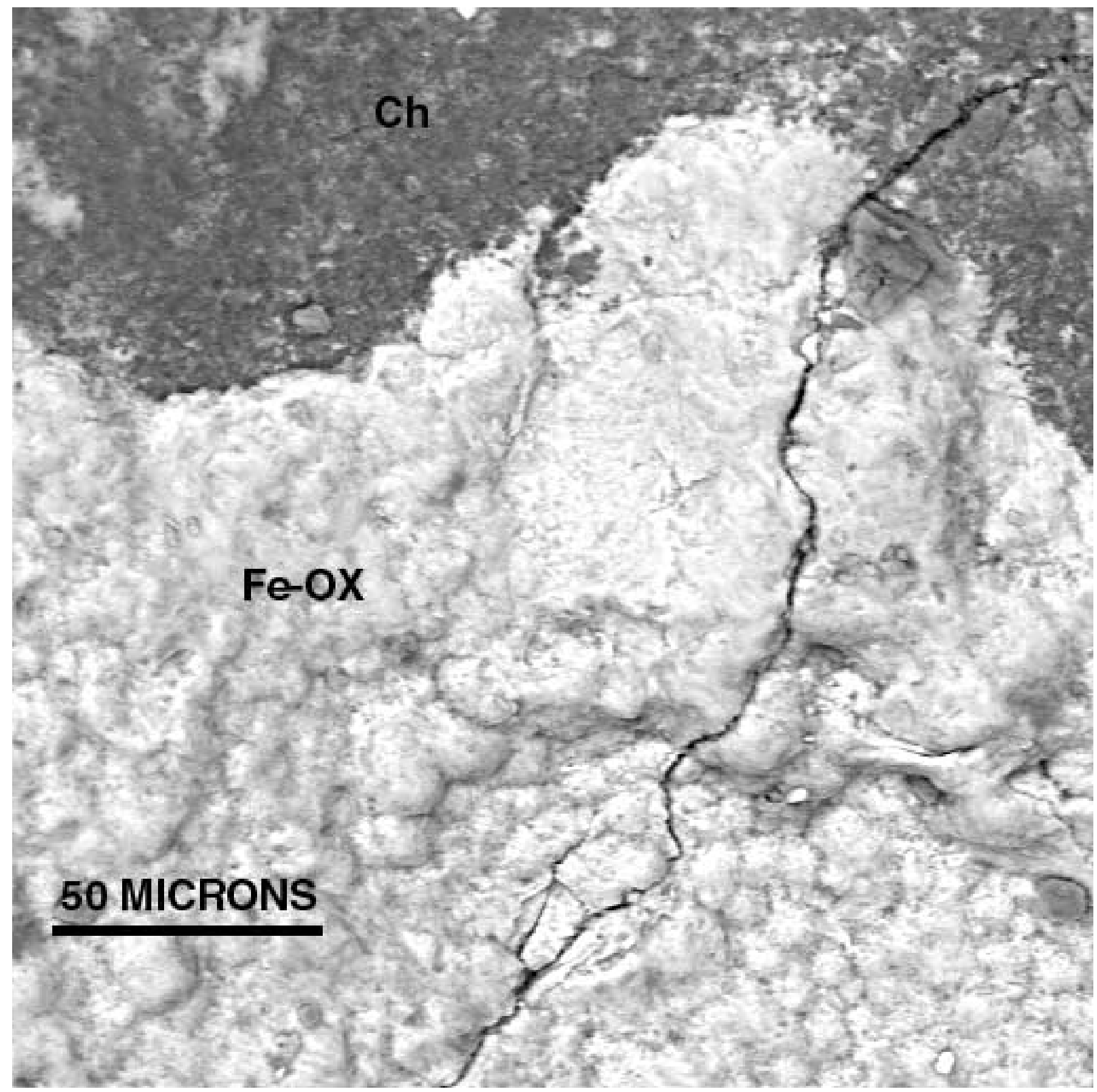

Figure 40. UE-29a\#2, 812.1-812.2 feet. Back scattered electron image showing botryoidal Fe-oxide accumulation (Fe-OX) developed on chalcedonic silica (Ch). 


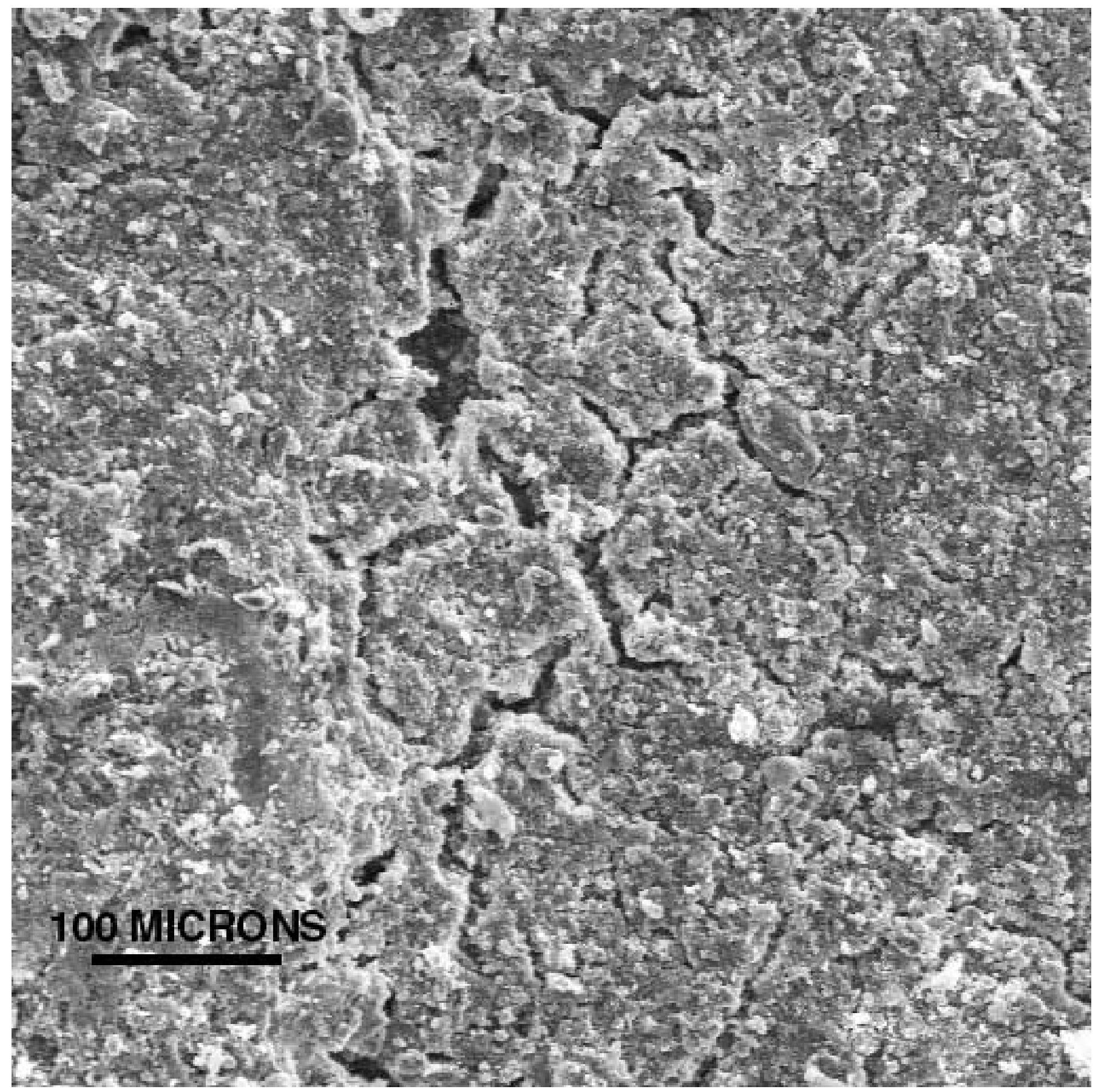

Figure 41. UE-29a\#2, 817.8-817.9 feet. Secondary electron image showing well-developed dessication cracks in mixed clay (illite/smectite) plus chalcedony mat on fracture surface. 


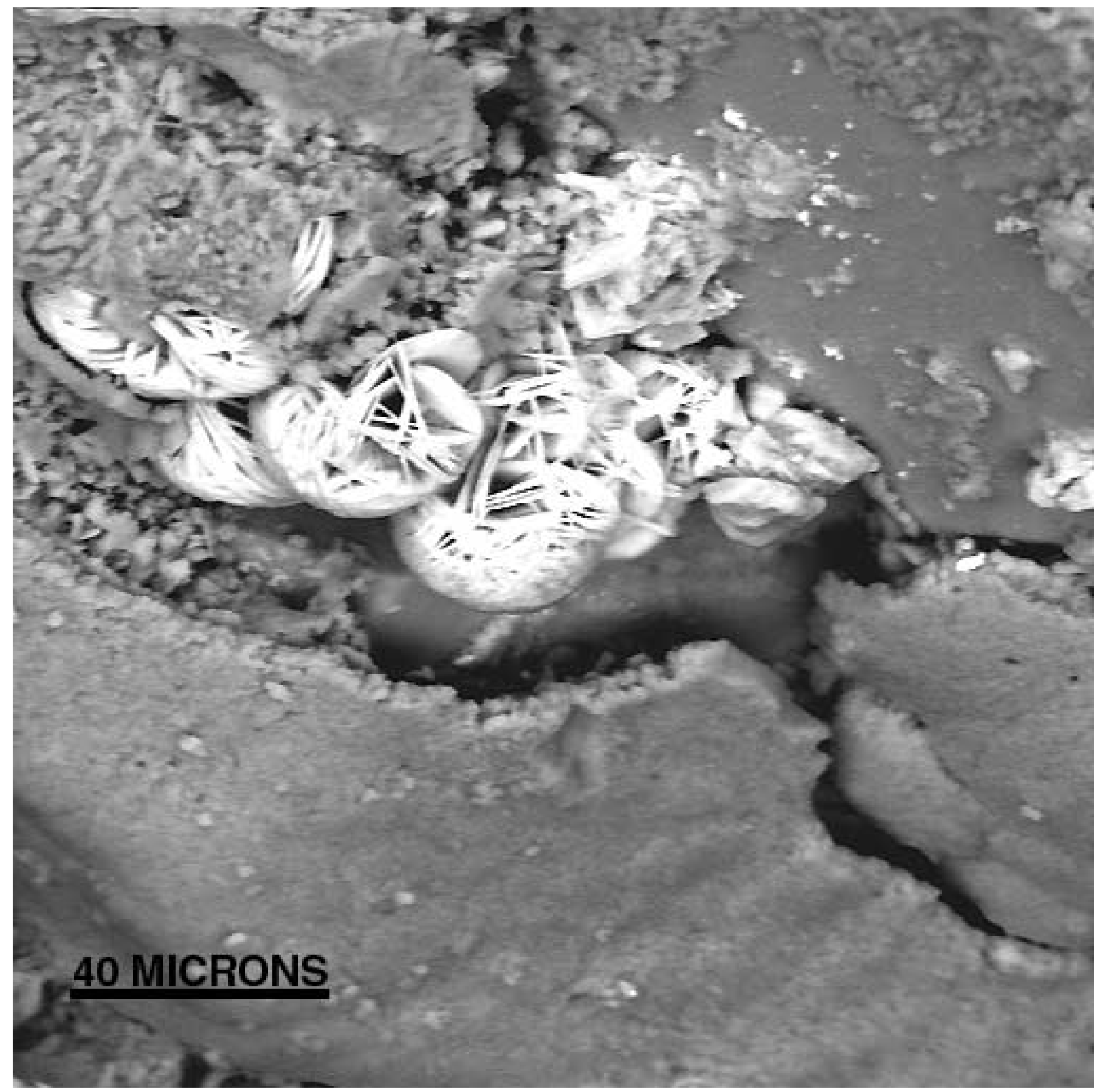

Figure 42. ER-OV-3c, 510-540 feet. Back scattered electron image showing Fe-oxide (hematite?) rosettes that have been exposed where the late phase, predominantly chalcedonic coating has broken away. 


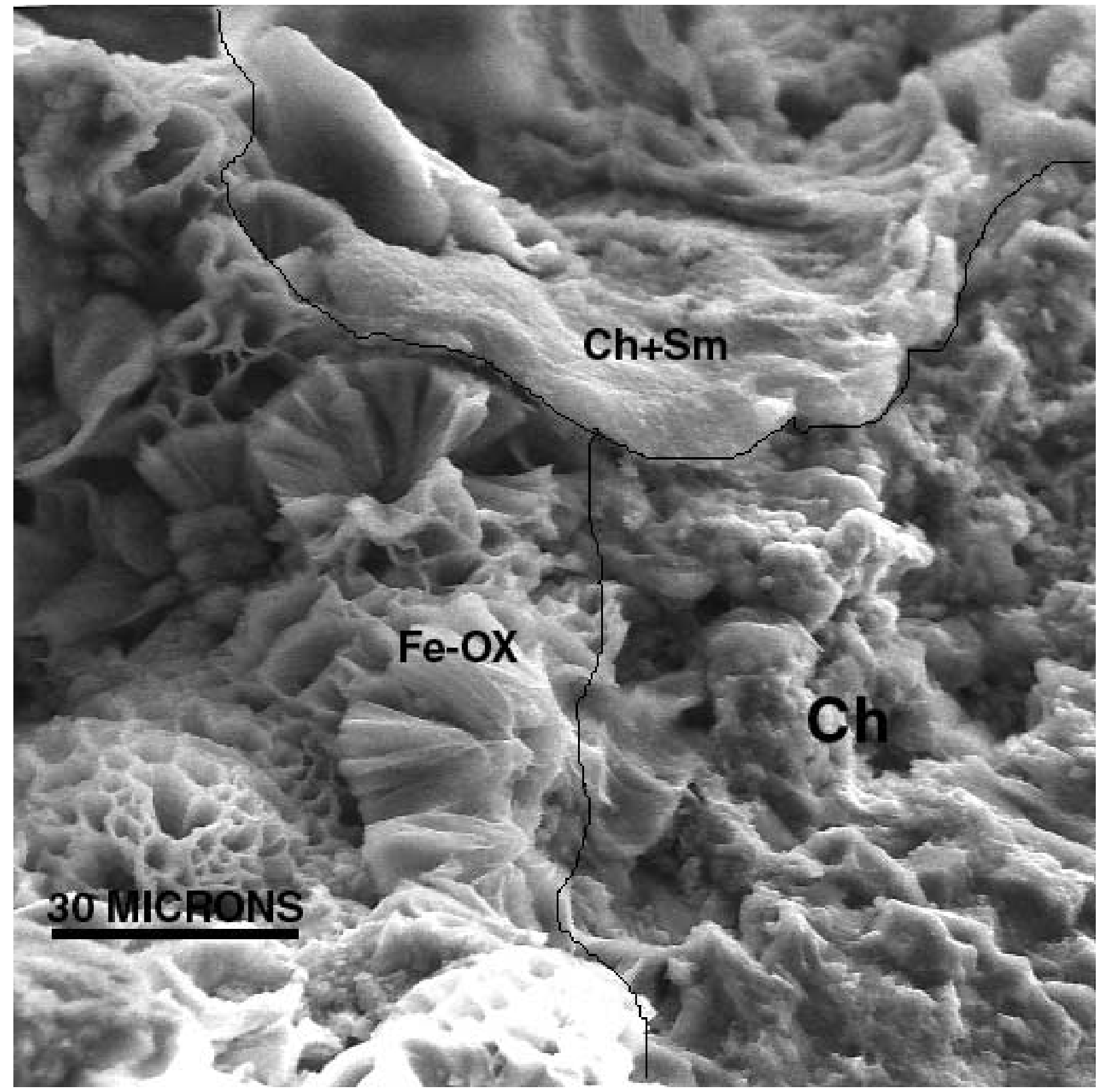

Figure 43. ER-OV-3c, 510-540 feet. Secondary electron image showing highly porous, lacy Fe-oxide (Fe-OX) in association with chalcedony $(\mathrm{Ch})$ and mixed chalcedony plus probable smectite clay $(\mathrm{Ch}+\mathrm{Sm})$. 


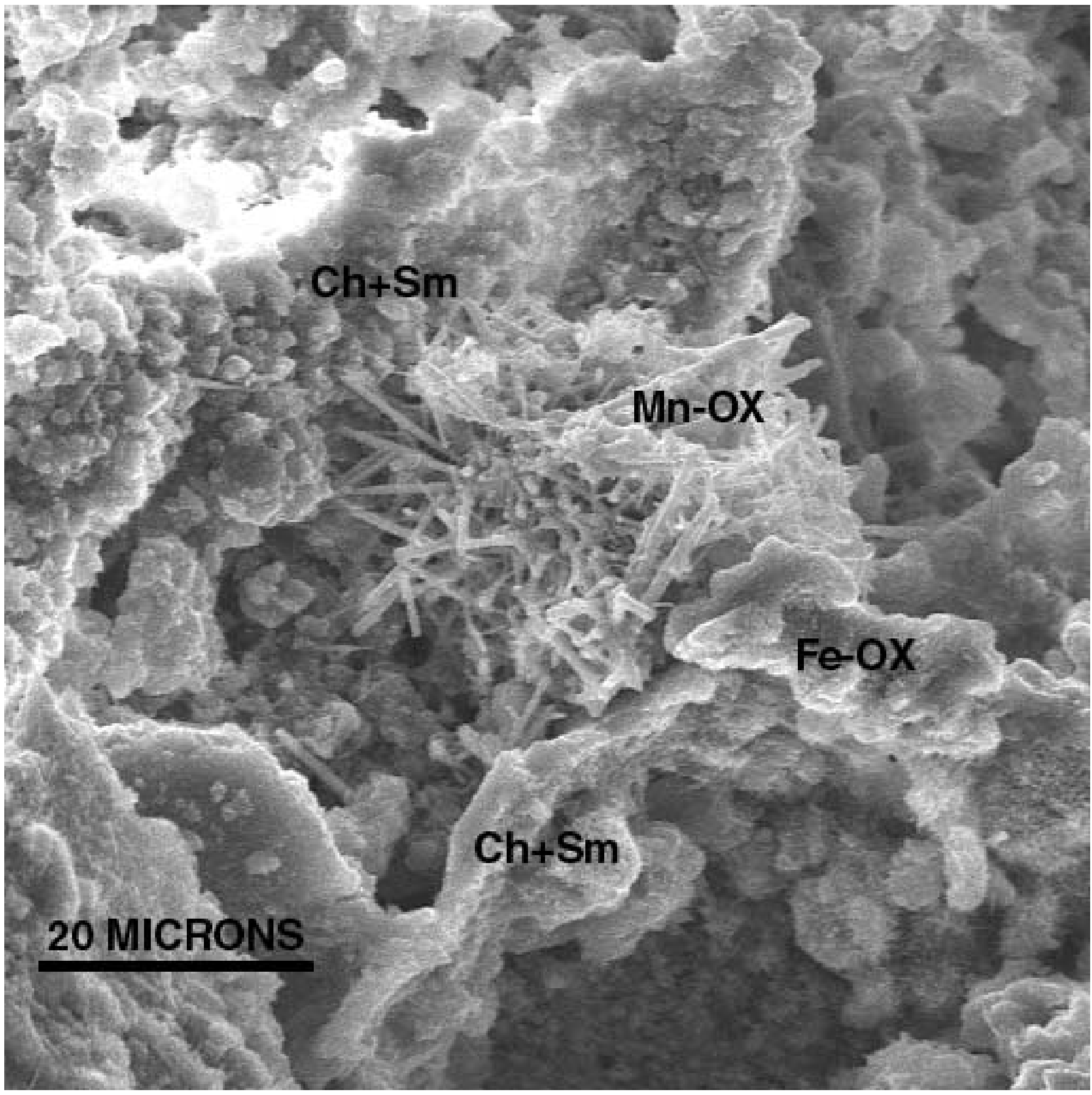

Figure 44. ER-OV-3c2, 270-320 feet. Secondary electron image showing irregular Fe-oxide aggregate (Fe-OX) and roughly radial aggregate of prismatic $\mathrm{Mn}$-oxide $(\mathrm{Mn}-\mathrm{OX})$ visible where veil of chalcedony plus clay mat has broken away. 


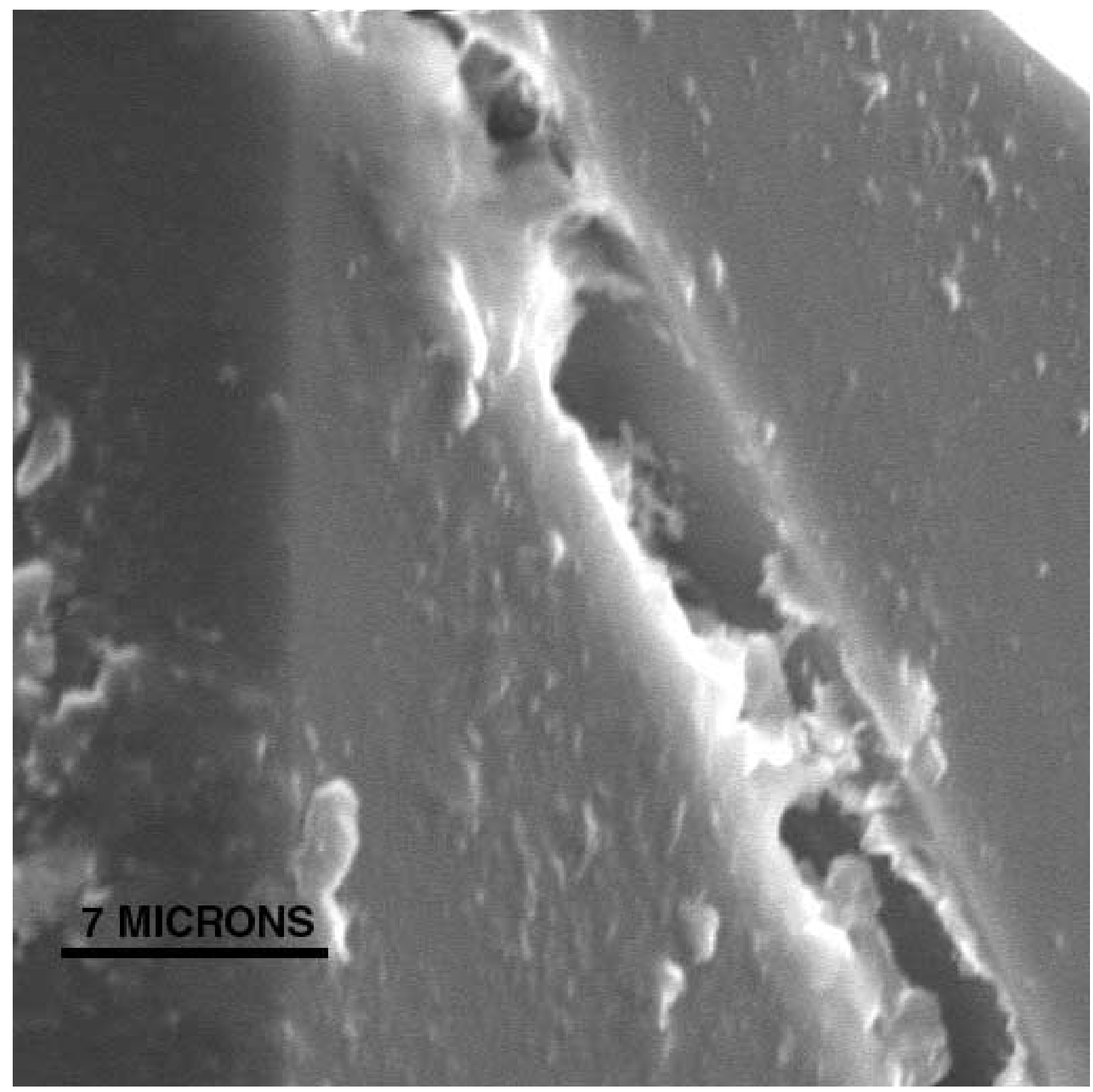

Figure 45. ER-OV-6a2. Secondary electron image showing partially healed fracture in quartz. 
Appendix 2 


\section{Appendix 2 \\ Description of Calcite Samples Analyzed for Stable Isotopes and Trace Elements}

All descriptions are for samples obtained from drill cuttings. Stratigraphic assignments for the ER-EC wells and ER-18-2 are based on lithologic logs provided by Lance Prothro (Bechtel Nevada; written communication, 1999).

\section{ER-EC-1}

middle screened interval

3480-3490 ft (1,060.7-1063.8 m) Prow Pass Tuff, Crater Flat Group.

Dense, glassy black vitrophyre with rare phenocrysts; contains sparse veinlets $(<1 \mathrm{~mm})$ of silica \pm carbonate.

Calcite occurs rarely in thin composite veinlets consisting of pink chalcedony rims and dense polycrystalline calcite cores; $\leq 1 \mathrm{~mm}$ in thickness.

lower screened interval

4520-4580 ft (1,392.9-1,396.0 m) Volcanics of Quartz Mountain.

Pinkish-gray flow banded rhyolite lava; silicified; $<5 \%$ phenocrysts, predominantly feldspar, with minor quartz.

Calcite occurs in small amounts as opaque, white to pale pink veins and dense polycrystalline intergrowths, lacking pore volume; veinlets and fracture coatings up to $3 \mathrm{~mm}$ in thickness. The surface of calcite veins shows etching patterns characteristic of partial dissolution.

\section{ER-EC-4}

upper screened interval

960-970 ft (292.6-295.7 m) Trachyte of Ribbon Cliff, Thirsty Canyon Group.

Brownish-black fine-grained lava, containing secondary magnetite $( \pm$ calcite \pm zeolites \pm chlorite \pm sulfides).

Calcite occurs as small fragments of vein material or vesicle fillings, in cuttings. Composite crystal aggregates up to $9 \mathrm{~mm}$ consist of euhedral, free-standing blades (individual crystals up to $4 \mathrm{~mm}$ ) with spaces between crystals. Crystal surfaces are commonly etched and milky colored, implying partial dissolution.

1150-1160 ft (350.5-353.5 m) Trachyte of Ribbon Cliff, Thirsty Canyon Group.

Dark grayish-brown lava with abundant small vesicles; lava contains tiny feldspar laths. Vesicles are commonly lined with zeolite minerals (especially clinoptilolite; levyne), silica, clays, and occasionally blocky prismatic calcite crystals.

Calcite was found as loose sharp, colorless, transparent, euhedral crystals up to $9 \mathrm{~mm}$ in length, elongated on the c-axis with well-developed prism faces and rhombohedral terminations. These evidently grew into a relatively large fracture (given their size and euhedral form). 
middle screened interval

1920-1930 ft (585.2-588.3 m) Trachyte of East Cat Canyon, Beatty Wash Formation.

Grayish-brown vesicular lava; devitrified; matrix contains small plagioclase laths and sulfide minerals (secondary?). Abundant Fe-oxide staining, possibly due to oxidation of sulfides. Vesicle lining minerals include opaline silica \pm calcite \pm greenish-colored clays.

Calcite occurs as fine-grained polycrystalline aggregates in vesicles (aggregates up to $1.2 \mathrm{~cm}$ ) intimately intermixed with chalky white opaline silica.

2210-2220 ft (673.6-676.7 m) Mafic-poor Ammonia Tanks Tuff, Timber Mountain Group. Moderately welded ash-flow tuff, lt. pinkish-brown with pumice fragments; contains phenocrysts of quartz, feldspar, and minor amounts of biotite.

Observed only a single polycrystalline mass of pale pink calcite, free of matrix. The sample was $17 \mathrm{~mm} \times 11 \mathrm{~mm} \times 8 \mathrm{~mm}$ in size, and consisted of densely intergrown blocky crystals up to $4 \mathrm{~mm}$. A second generation of small $(<1 \mathrm{~mm})$, free-standing colorless, euhedral calcite crystals formed on one edge of the larger mass.

\section{ER-EC-5}

\section{upper screened interval}

1190-1210 ft (362.7-368.8 m) Mafic-rich Ammonia Tanks Tuff, Timber Mountain Group. Moderately welded ash-flow tuff; light yellowish-brown to pinkish-brown color; contains abundant phenocrysts of feldspar + quartz + biotite $(\sim 30-35 \%$ of the rock mode); strongly silicified, with common silica fracture fillings (sometimes containing small open vugs).

Calcite is relatively common as $2-3 \mathrm{~mm}$ white veinlets that pinch and swell in thickness. Calcite is often associated with Mn-oxide minerals, which sometimes occur as inclusions within the calcite veins. Individual calcite crystals $(<1 \mathrm{~mm})$ are densely intergrown perpendicular to the rhyolite wall rock.

\section{middle screened interval}

1900-1910 ft (579.1-582.2 m) Mafic-rich Ammonia Tanks Tuff, Timber Mountain Group.

Moderately welded ash-flow tuff; medium pinkish-brown color; strongly silicified; abundant phenocrysts of feldspar + quartz + biotite.

Calcite occurs rarely as thin, crystallized fracture linings $(\leq 2 \mathrm{~mm})$ and as a microcrystalline alteration product of feldspar phenocrysts.

\section{lower screened interval}

2380-2390 ft (725.4-728.5 m) Mafic-poor Ammonia Tanks Tuff, Timber Mountain Group.

Moderately welded ash-flow tuff; medium yellowish-brown color; silicified; contains common phenocrysts of feldspar + quartz (+ minor biotite). Fe- and Mn-oxides commonly occur as thin fracture coatings, sometimes in association with thin calcite veinlets.

Calcite forms sparse, thin fracture coatings $(\leq 1 \mathrm{~mm})$ on the surfaces of tuffaceous volcanic rock. The vein material was easily flaked off the surface (poorly attached), and had an etched appearance. 


\section{ER-EC-6}

\section{second screened interval}

2230-2250 ft (679.7-685.8 m) Rhyolite of Scrugham Peak, Paintbrush Group.

Non-welded tuff; lt. gray to pale yellow-brown; silicified; contains minor feldspar + quartz phenocrysts; feldspars and pumice fragments are strongly argillized.

Calcite is very sparse, occurring as compact veinlets (up to $3 \mathrm{~mm}$ in thickness) on fracture surfaces, associated with black Mn-oxides. Also with clay minerals, as partial replacements of feldspar phenocrysts.

\section{third screened interval}

3420-3440 ft (1,042.4-1,048.5 m) Topopah Spring Tuff, Paintbrush Group.

Partially welded ash-flow tuff; light gray to pinkish-gray containing abundant feldspar phenocrysts, with less abundant quartz and biotite (commonly chloritized); matrix is silicified, and contains thin veinlets of secondary quartz.

Calcite is rare, but is found as thin fracture fillings consisting of small, densely intergrown white crystals. The largest piece of calcite was a loose vein fragment measuring $8 \mathrm{~mm} \times 4 \mathrm{~mm} \times 1.5$ $\mathrm{mm}$, with small amounts of matrix present on both sides of the vein; calcite completely fills the fracture.

\section{ER-EC-7}

\section{lower screened interval}

1180-1200 ft (359.7-365.8 m) Caldera moat-filling sedimentary deposits.

Tuffaceous gravels consisting of pinkish-gray to brown fragments of rhyolite lava and welded tuff.

Calcite occurs in small amounts as loose single crystals; commonly euhedral, thin tabular to bladed habit; colorless; translucent. Individual crystals are up to $3 \mathrm{~mm}$ in size, and are sometimes stacked in parallel growth. Crystal surfaces appear to be weakly etched.

\section{ER-EC-8}

\section{lower screened interval}

1850-1870 ft (563.9-570.0 m) Mafic-poor Ammonia Tanks Tuff, Timber Mountain Group. Moderately welded ash-flow tuff; yellow-brown with common pumice fragments; abundant phencrysts of feldspar and quartz, with minor amounts of biotite.

Platy to bladed calcite crystals and vein fragments are relatively abundant in the cuttings from this interval. Calcite is milky white, with a pearly luster on cleavage surfaces. Individual crystals are commonly stacked in subparallel growth, parallel to the fracture plane. Vein fragments (up to $2 \mathrm{~mm}$ thick) are sometimes associated with small $(<1 \mathrm{~mm})$ euhedral quartz crystals embedded within the calcite vein. 


\section{ER-18-2}

\section{single screened interval}

2050-2080 ft (624.8-634.0 m) Mafic-rich Ammonia Tanks Tuff, Timber Mountain Group. Moderately welded ash-flow tuff; medium pinkish-brown with common pumice; abundant white (altered) phenocrysts of feldspar, with common quartz, and abundant biotite (up to 5\%). Small silica veins stained with Fe-oxides are relatively common.

Calcite veins and fracture fillings are common in this interval, sometimes associated with hematite and black Mn-oxides. Relatively large individual milky-white calcite crystals (up to $14 \mathrm{~mm}$ in length) formed in tight, narrow fractures (maximum thickness: $2 \mathrm{~mm}$ ). The larger crystals are commonly free of matrix, and show evidence of etching (partial dissolution?) on their surfaces.

\section{ER-OV-3a}

\section{Near-surface sample}

$20 \mathrm{ft}(6.1 \mathrm{~m})$ Quaternary alluvium

Light yellowish-brown sandy clayey gravel; contains abundant subangular tuffaceous lithic fragments (typically $\leq 3 \mathrm{~mm}$ ) and felsic crystal fragments $(<1 \mathrm{~mm})$ in a silt/clay matrix; moderately sorted; poorly indurated.

Secondary calcite is present in minor amounts, disseminated in the fine-grained matrix. Although the calcite is not visible, the cuttings are weakly effervescent in dilute $\mathrm{HCl}$.

\section{ER-30-1}

\section{upper screened interval}

580-610 ft (176.8-185.9 m) Lava Dome Mtn Basalt

Dark gray to reddish brown lava containing sparse plagioclase phenocrysts; vesicular in places. Chalky opaline silica and calcite are relatively common as thin veinlets, and as vesicle fillings.

Calcite veinlets are typically $1 \mathrm{~mm}$ in maximum thickness, consisting of densely intergrown microcrystalline aggregates completely filling fractures. Some calcite is pale peach colored due to Fe-oxide inclusions.

\section{lower screened interval}

750-760 ft (228.6-231.6 m) Rhyolite of Chukar Canyon, Beatty Wash Formation Light brown reworked air-fall tuff containing subrounded white pumice fragments $(\leq 5 \mathrm{~mm})$, tuffaceous lithic fragments $(\leq 4 \mathrm{~mm})$, and abundant feldspar and quartz crystal fragments $(<1$ $\mathrm{mm}$ ) in a matrix of fine-grained calcite + clay matrix.

Calcite is abundant (perhaps $10 \%$ by volume) as a secondary cement, occurring as coarse spar crystals filling voids, and as a thick mantle on pumice and lithic fragments. 
